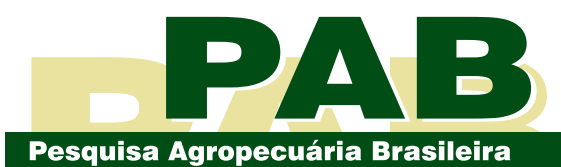

ISSN 1678-3921

Journal homepage: www.embrapa.br/pab

For manuscript submission and journal contents, access: www.scielo.br/pab

\title{
Recommendations for assessing earthworm populations in Brazilian ecosystems
}

\begin{abstract}
Earthworms are often related to fertile soils and are also frequently used as environmental quality indicators. However, to optimize their use as bioindicators, earthworm populations must be evaluated together with the environmental and anthropogenic variables regulating their communities. This review sought to identify the earthworm-sampling, soil chemical and physical, and environmental and anthropogenic attributes evaluated in 124 published studies that quantified earthworm abundance ( $>7,300$ samples) in 765 sites with different types of climate, soils, land use, and management systems in Brazil. Soil chemical and physical attributes (except $\mathrm{pH}$ ) were less reported ( $\leq 50 \%$ of studies) than other environmental variables such as sampling date, altitude, temperature, precipitation, climate and soil type, and land use ( $>50 \%$ of studies). Earthworms were rarely identified $(24 \%)$ and few studies (31\%) measured their biomass, although most provided adequate information on sampling protocol. Based on their importance in regulating earthworm populations, a set of variables is proposed to be evaluated when studying earthworm communities and other macrofauna groups. This should help guide future studies on earthworms in Brazil and other countries, optimize data collection and replicability, allow comparisons between different studies, and promote the use of earthworms as soil quality bioindicators.
\end{abstract}

Index terms: bioindicators, macrofauna, Oligochaeta, soil quality.

\section{Recomendações para avaliação de populações de minhocas em ecossistemas brasileiros}

Resumo - As minhocas são frequentemente relacionadas a solos férteis e, também, bastante usadas como indicadores da qualidade ambiental. No entanto, para otimizar seu uso como bioindicadores, as populações de minhocas devem ser avaliadas juntamente com as variáveis ambientais e antropogênicas que regulam as suas comunidades. Esta revisão buscou identificar os atributos relacionados à amostragem de minhocas, físicos e químicos dos solos, e ambientais e antropogênicos avaliados em 124 estudos publicados que quantificaram a abundância de minhocas ( $>7.300$ amostras) em 765 locais com diferentes tipos de clima, solos, uso da terra e sistemas de manejo no Brasil. Os atributos químicos e físicos do solo (exceto $\mathrm{pH}$ ) foram menos relatados ( $\leq 50 \%$ dos estudos) do que outras variáveis ambientais, como data de coleta, altitude, temperatura, precipitação, tipo de solo e de clima, e uso do solo ( $>50 \%$ dos estudos). As minhocas foram raramente identificadas (24\%) e poucos estudos (31\%) mediram sua biomassa, embora a maioria tenha fornecido informações adequadas sobre o protocolo de amostragem. Com base na sua importância para a regulação das populações de minhocas, propõe-se um conjunto de variáveis que devem ser avaliadas no estudo de comunidades de minhocas e outros grupos da macrofauna do solo. Isso deve ajudar a guiar futuros estudos sobre minhocas no Brasil e em outros países, 


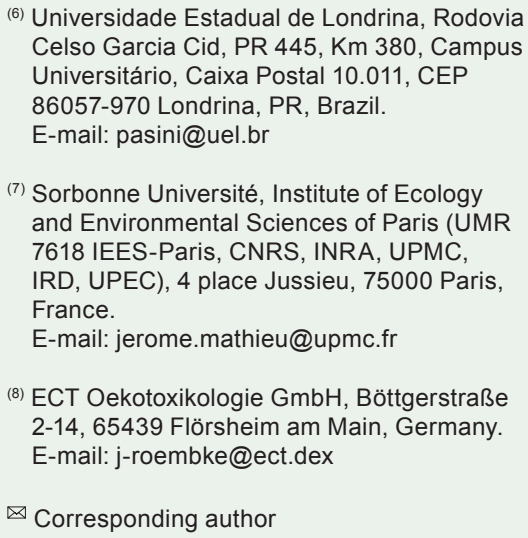

otimizar a coleta e a replicabilidade de dados, permitir comparações entre diferentes estudos e promover o uso de minhocas como bioindicadores da qualidade do solo.

Termos para indexação: bioindicadores, macrofauna, Oligochaeta, qualidade do solo.

\section{Introduction}

Earthworms are among the most well-known soil animals, being ecosystem engineers (Jones et al., 1994; Lavelle et al., 1997) that actively contribute to many ecosystem services, including carbon sequestration and gaseous exchanges, plant production, and erosion control, as well as soil genesis, decomposition, and nutrient cycling (Stockdale \& Watson, 2012; Jouquet et al., 2014; Brown et al., 2015). Most farmers and gardeners are quick to recognize the value of earthworms for soil fertility (Brown et al., 2003; Lima \& Brussaard, 2010) and tend to associate the presence of a high number of earthworms with more fertile soils.

The community and abundance of earthworms at a given location are controlled by several biotic and abiotic factors, which act at different spatial scales (Figure 1) and include: climatic conditions, such as climate type, especially precipitation and temperature; soil properties, mainly its type and chemical and physical conditions, among which stand out $\mathrm{pH}$, organic matter, moisture, and texture; vegetation, indicating the type of ecosystem, primarily plant cover; and history of the site, particularly human activities but also geological processes (Reynolds \& Jordan, 1975; Brown \& Domínguez, 2010). At the largest spatial scale, climate is the most important hierarchical factor (Lavelle et al., 1993; Phillips et al., 2019), because it generally regulates the biome and type of ecosystem (vegetation), also influencing the formation of soil layers (Blume et al., 2016). At lower spatial scales, that is, at regional and local levels, other important determinants of earthworm communities are: human disturbance, such as soil management; type of crop or forest plantation; and inputs and cultural practices, including tillage and pesticide and fertilizer use (Curry, 2004). All these directly or indirectly affect many of the soil characteristics that are important for earthworms, like organic matter content, $\mathrm{pH}$, and nutrients, as well as plant productivity and cover that influence litter quality and quantity and soil temperature (Curry, 2004). At the lowest spatial scale, i.e., within a soil profile of a particular site, it is mainly the soil physical and chemical characteristics that affect the soil as a habitat for earthworms and also the interactions (e.g., predation, parasitism, and mutualism) with other organisms (e.g. other soil biota) that can affect earthworm populations (Brown \& Domínguez, 2010).

Because of their usefulness as environmental and, particularly, as soil quality indicators, earthworm communities have been regularly studied in European countries (Fründ et al., 2011; Pulleman et al., 2012; Bünemann et al., 2018). Unfortunately, so far, there are few 
nation-wide monitoring programs in place, but both public and scientific interest in the state of the soil organism community, mainly of earthworms, are growing notably in France, the Netherlands, and Germany (Jeffery et al., 2010; Cluzeau et al., 2012; Römbke et al., 2016). In Brazil, the use of earthworm communities as bioindicators has been explored in several publications (Nunes et al., 2007; Uzêda et al., 2007; Andréa, 2010; Bartz et al., 2010; Fernandes et al., 2010; Lima \& Brussaard, 2010; Marichal et al., 2010; Rousseau et al., 2010); however, up to now, only one earthworm-based soil quality classification has been proposed, considering the density of these invertebrates in areas under no-tillage in the western region of the state of Paraná, Southern Brazil (Bartz et al., 2013). Based on earthworm abundance, these authors classified soil quality under no-tillage in four classes: poor, with $<25$ individuals per square meter; moderate, with $\geq 25-100$ individuals per square meter; good, with > 100-200 individuals per square meter; and excellent, with $>200$ individuals per square meter. Earthworm abundance in farms was positively related to the sum of bases, but negatively associated with soil organic matter contents. Clearly, there is still much to be done both in Brazil and even worldwide concerning the use of earthworms for the indication of soil quality and monitoring purposes, especially considering the relative ease and low cost of sampling and the value given by land managers to earthworms.

Due to the large variety of factors that can influence earthworm communities in soils, the use of these organisms as bioindicators requires the sampling of

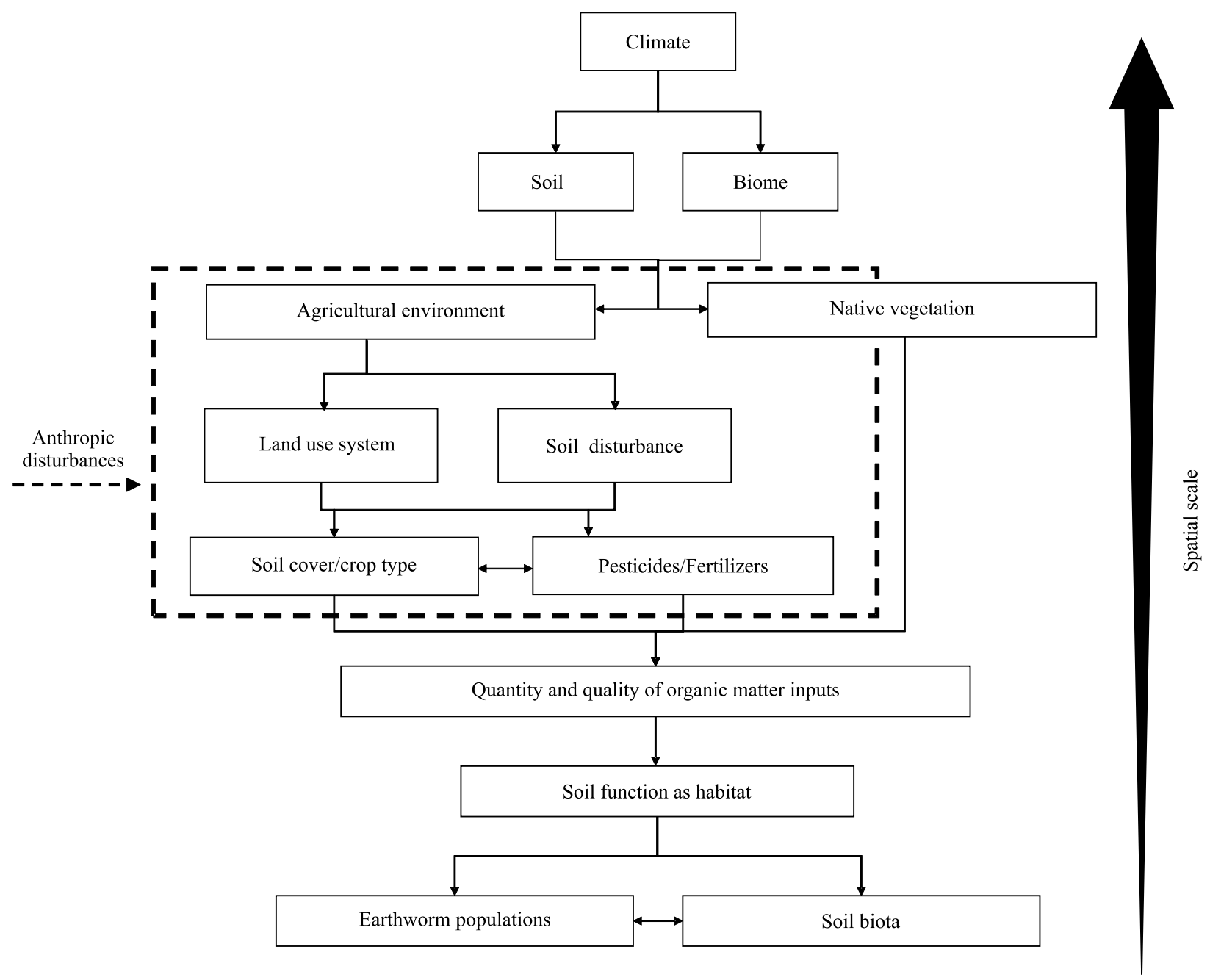

Figure 1. Hierarchical model of the factors that determine earthworm communities in Brazilian ecosystems. 
several environmental data and soil attributes that are important for the soil to function and to work as a habitat for the development and activity of earthworm populations (Römbke et al., 2005). Furthermore, in order to be able to compare the effects of different ecosystems, types of vegetation, and land use management systems on earthworm populations, the collection of data - on the environment, earthworm communities, and soil - must be standardized in each study and between studies, e.g., according to the International Organization for Standardization (ISO, 2018). Standardization proposals have been made before (Römbke et al., 2006; Römbke, 2007) and are available in ISO (2018), but their level of adoption is quite variable and often requires local adaptations (Silva et al., 2019).

Therefore, the aim of this review was to assess the environmental and soil variables considered in the studies that quantitatively sampled earthworms in Brazil, and, based on this literature survey, to propose a set of variables that should be evaluated when studying earthworm populations. This should help guide future studies on earthworms in Brazil and other countries, optimize data collection, allow comparisons between different studies, and promote the use of earthworm communities as soil quality bioindicators in Brazilian ecosystems.

\section{Characterization of studies on earthworm populations in Brazil}

For this review, studies on earthworm populations in Brazilian ecosystems published from 1976 to 2017 were considered, being obtained from searchable online databases such as Web of Science, Scielo, Lattes-CNPq Platform, Biblioteca Digital de Teses e Dissertações, Google Scholar, and the Alice repository of Empresa Brasileira de Pesquisa Agropecuária (Embrapa). For an exhaustive review and to determine which soil, environmental, management, earthworm, and sampling-related factors were evaluated, non-indexed journals, book chapters, and conference proceedings on soil science, zoology, ecology, agroecology, and conservation agriculture were also included.

Over 150 studies on earthworm populations or soil macrofauna in general, including earthworms, were found. Different methods were used to sample earthworms and to make them rise to the soil surface
(Peixoto \& Marochi, 1996; Römbke et al., 1999; Ressetti, 2006; Ressetti et al., 2008; Steffen et al., 2013), including chemical solutions, such as diluted formaldehyde, mustard or onion extracts, or their main chemical components, e.g., Allyl isothiocyanate (AITC) (Zaborski, 2003; Pelosi et al., 2009). Although, in some locations, some species of earthworms particularly epigeics, epi-endogeics, or anecics may be better sampled by chemical extraction or by combining both hand-sorting and chemical extraction (Römbke et al., 1999; Römbke, 2007), only handsorting studies were selected, because this was the most common method used and would allow a more thorough comparison between studies. Studies were excluded when they did not present data on earthworm density per sample site, but rather as a means per land use system or type of soil management in several sites, making data recovery from individual sites impossible (Mathieu et al., 2009; Marichal et al., 2010; Pimentel et al., 2011a; Baretta et al., 2013; Vasconcellos et al., 2013; Rousseau et al., 2014; Santos et al., 2016).

This resulted in the evaluation of a total of 124 published studies that are listed in Table 1, which includes the source and location (municipality and state in Brazil) of the study, biome, land use systems sampled, number of sites, and type of measurements performed (earthworm density and/or biomass and associated soil data). Overall, only about $40 \%$ of all studies were journal articles and a large proportion $(\sim 60 \%)$ were material produced outside the traditional commercial or academic publishing and distribution channels, including 36 theses and dissertations and 44 conference proceedings papers.

The data on soil, environmental, and earthworm sampling variables, as well as on the management practices adopted at each sampling site, obtained from the 124 publications are available for download at Dryad, an online open-access repository (Nadolny et al., 2020). This dataset provides information on the number of publications containing each environmental, earthworm, and soil physical and chemical variable, besides the corresponding number of points/sampling sites and their proportion. The data covers over 7.300 earthworm samples, from a wide range of soils, vegetation types, and management systems in Brazil. In the following sections, these studies and their data were reviewed according to the geographical spread of the samples, climate and vegetation-related variables,

Pesq. agropec. bras., Brasília, v.55, e01006, 2020

DOI: 10.1590/S1678-3921.pab2020.v55.01006 
Table 1. Location of the experiment, land use systems evaluated, number of sampled sites, and type of data identified in the 124 published studies on earthworm populations in Brazilian ecosystems, used to build the database available at Nadolny et al. (2020).

\begin{tabular}{|c|c|c|c|c|c|c|}
\hline Study & Biome & Municipality - State & Land use system ${ }^{(1)}$ & Number $^{(2)}$ & $\operatorname{Data}^{(3)}$ & References \\
\hline 1 & Pampa & Pelotas, Morro Redondo - RS & Crop & 4 & $\mathrm{a}, \mathrm{b}, \mathrm{s}$ & Schiavon (2012) \\
\hline 2 & Pampa & Pelotas - RS & $\begin{array}{l}\text { Native vegetation, forestry } \\
\text { plantation, crop }\end{array}$ & 5 & a & Schiavon et al. (2009) \\
\hline 3 & Pampa & Pelotas, São Lourenço do Sul - RS & IPS & 4 & $\mathrm{a}$ & Hipólito et al. (2015) \\
\hline 4 & Pampa & Santa Maria - RS & Crop & 5 & $\mathrm{a}$ & Giracca et al. (2005) \\
\hline 5 & Pampa & Santa Maria - RS & Crop & 5 & $\mathrm{a}$ & Campos et al. (1997) \\
\hline 6 & Atlantic Forest & Teutônia - RS & Crop, native vegetation & 4 & $\mathrm{a}, \mathrm{s}$ & Krabbe et al. (1993) \\
\hline 7 & Atlantic For-est & Campos Novos $-\mathrm{SC}$ & Crop & 6 & $\mathrm{a}, \mathrm{s}$ & Alves (2007) \\
\hline 8 & Atlantic For-est & Canoinhas $-\mathrm{SC}$ & Crop & 4 & $\mathrm{a}, \mathrm{b}, \mathrm{s}$ & Freitas (2007) \\
\hline 9 & Atlantic For-est & Chapecó - SC & $\begin{array}{l}\text { Crop, pasture, native } \\
\text { vegetation }\end{array}$ & 7 & $\mathrm{a}, \mathrm{s}$ & Baretta et al. (2003) \\
\hline 10 & Atlantic Forest & Florianópolis - SC & $\begin{array}{l}\text { Native vegetation, forestry } \\
\text { plantation }\end{array}$ & 5 & a & Gois et al. (2007) \\
\hline 11 & Atlantic Forest & Lages - SC & $\begin{array}{l}\text { Native vegetation, forestry } \\
\text { plantation }\end{array}$ & 3 & $\mathrm{a}, \mathrm{s}$ & Pompeo et al. (2016) \\
\hline 12 & Atlantic For-est & Orleans - SC & $\begin{array}{l}\text { Native vegetation, pasture, } \\
\text { crop }\end{array}$ & 4 & $\mathrm{a}, \mathrm{s}$ & $\begin{array}{l}\text { Alberton et al. (2010); } \\
\text { Oliveira Filho (2009) }\end{array}$ \\
\hline 13 & Atlantic For-est & Antonina - PR & $\begin{array}{l}\text { Native vegetation, pasture, } \\
\text { crop, IPS }\end{array}$ & 6 & $\mathrm{a}, \mathrm{b}$ & Maschio et al. (2010) \\
\hline 14 & Atlantic For-est & $\begin{array}{l}\text { Antonina, Guaraqueçaba, } \\
\text { Paranaguá - PR }\end{array}$ & $\begin{array}{l}\text { Pasture, native vegetation, } \\
\text { crop, IPS }\end{array}$ & 51 & $\mathrm{a}, \mathrm{b}, \mathrm{s}$ & Römbke et al. (2009) \\
\hline 15 & Atlantic For-est & $\begin{array}{l}\text { Arapongas, Londrina, } \\
\text { Rolândia - PR }\end{array}$ & $\begin{array}{l}\text { Native vegetation, pasture, } \\
\text { crop }\end{array}$ & 5 & $\mathrm{a}, \mathrm{b}, \mathrm{s}$ & Bartz et al. (2014) \\
\hline 16 & Atlantic Forest & $\begin{array}{l}\text { Barra do Turvo - SP, } \\
\text { Adrianópolis - PR }\end{array}$ & IPS, native vegetation & 6 & $\mathrm{a}, \mathrm{b}, \mathrm{s}$ & Brown et al. (2009) \\
\hline 17 & Atlantic Forest & Bela Vista do Paraíso - PR & $\begin{array}{c}\text { Crop, native vegetation, } \\
\text { pasture }\end{array}$ & 12 & $\mathrm{a}, \mathrm{b}$ & $\begin{array}{l}\text { Benito (2002); Brown } \\
\text { et al. (2003) }\end{array}$ \\
\hline 18 & Atlantic Forest & Bituruna - PR & Crop, native vegetation & 3 & a & Bianchi et al. (2007) \\
\hline 19 & Atlantic Forest & $\begin{array}{c}\text { Cafeara, Campo Mourão, Cornélio } \\
\text { Procópio, Jataizinho, Londrina, } \\
\text { Sertanópolis, São Jerônimo da } \\
\text { Serra - PR }\end{array}$ & $\begin{array}{l}\text { Crop, pasture, native } \\
\text { vegetation }\end{array}$ & 29 & $\mathrm{a}, \mathrm{b}$ & $\begin{array}{l}\text { Brown et al. (2003, } \\
2004,2008)\end{array}$ \\
\hline 20 & Atlantic Forest & Londrina - PR & Crop & 6 & $a, b$ & $\begin{array}{l}\text { Brown et al. (2001, } \\
\text { 2004) }\end{array}$ \\
\hline 21 & Atlantic Forest & Rolândia - PR & $\begin{array}{l}\text { Crop, IPS, pasture, native } \\
\text { vegetation }\end{array}$ & 4 & $\mathrm{a}, \mathrm{s}$ & $\begin{array}{l}\text { Benito et al. (2008); } \\
\text { Brown et al. (2003) }\end{array}$ \\
\hline 22 & Atlantic Forest & Campina Grande do Sul - PR & Native vegetation & 8 & $\mathrm{a}, \mathrm{b}, \mathrm{s}$ & Cardoso et al. (2014) \\
\hline 23 & Atlantic Forest & Castro - PR & Crop, native vegetation & 4 & $\mathrm{a}, \mathrm{b}, \mathrm{s}$ & $\begin{array}{l}\text { Tanck (1996); Tanck et } \\
\text { al. (2000) }\end{array}$ \\
\hline 24 & Atlantic Forest & Cianorte $-\mathrm{PR}$ & IPS, pasture & 2 & $\mathrm{a}, \mathrm{b}$ & Jardeveski (2005) \\
\hline 25 & Atlantic Forest & Clevelândia - PR & Crop & 2 & $\mathrm{a}, \mathrm{s}$ & Trogello et al. (2008) \\
\hline 26 & Atlantic Forest & Colombo - PR & $\begin{array}{l}\text { Forestry plantation, native } \\
\text { vegetation }\end{array}$ & 15 & $\mathrm{a}, \mathrm{b}, \mathrm{s}$ & $\begin{array}{l}\text { Lima (2011); Santos et } \\
\text { al. (2016); Silva (2010) }\end{array}$ \\
\hline
\end{tabular}

Continuation... 
Continuation...

\begin{tabular}{|c|c|c|c|c|c|c|}
\hline Study & Biome & Municipality - State & Land use system ${ }^{(1)}$ & Number $^{(2)}$ & $\operatorname{Data}^{(3)}$ & Reference \\
\hline 27 & Atlantic Forest & Colombo-PR & Forestry plantation & 5 & $\mathrm{a}, \mathrm{b}, \mathrm{s}$ & $\begin{array}{l}\text { Maschio (2012); } \\
\text { Maschio et al. (2014) }\end{array}$ \\
\hline 28 & Atlantic Forest & Colorado - PR & Crop, native vegetation & 5 & $\mathrm{a}, \mathrm{s}$ & $\begin{array}{l}\text { Pasqualin (2009); } \\
\text { Pasqualin et al. (2012) }\end{array}$ \\
\hline 29 & Atlantic Forest & General Carneiro - PR & Crop, native vegetation & 6 & $\mathrm{a}, \mathrm{b}$ & Mafra et al. (2002) \\
\hline 30 & Atlantic Forest & Jaguapitã - PR & $\begin{array}{l}\text { Crop, pasture, native } \\
\text { vegetation }\end{array}$ & 11 & $\mathrm{a}, \mathrm{b}, \mathrm{s}$ & $\begin{array}{l}\text { Nunes (2006); Nunes } \\
\text { et al. (2007) }\end{array}$ \\
\hline 31 & Atlantic Forest & Jardim Olinda - PR & IPS & 4 & $\mathrm{a}, \mathrm{s}$ & Franchini et al. (2009) \\
\hline 32 & Atlantic Forest & Londrina - PR & $\begin{array}{l}\text { Crop, native vegetation, } \\
\text { pasture }\end{array}$ & 6 & $\mathrm{a}, \mathrm{b}, \mathrm{s}$ & Fernandes (2009) \\
\hline 33 & Atlantic Forest & Londrina - PR & Crop, native vegetation & 6 & $\mathrm{a}, \mathrm{b}, \mathrm{s}$ & Bartz et al. (2009a) \\
\hline 34 & Atlantic Forest & Londrina $-\mathrm{PR}$ & $\begin{array}{l}\text { Crop, native vegetation, } \\
\text { pasture }\end{array}$ & 4 & $\mathrm{a}, \mathrm{b}$ & $\begin{array}{l}\text { Azevedo et al. (2010); } \\
\text { Brown et al. (2008) }\end{array}$ \\
\hline 35 & Atlantic Forest & Londrina, Rolândia - PR & Crop & 7 & $\mathrm{a}, \mathrm{s}$ & $\begin{array}{l}\text { Derpsch et al. (1986); } \\
\text { Kemper \& Derpsch } \\
(1980 / 1981,1981)\end{array}$ \\
\hline 36 & Atlantic Forest & Miraselva - PR & Pasture, native vegetation & 4 & a & Benito (2005) \\
\hline 37 & Atlantic Forest & Paranaguá - PR & Native vegetation, IPS & 2 & $\mathrm{a}, \mathrm{s}$ & Santos et al. (2015) \\
\hline 38 & Atlantic Forest & Pinhais - PR & Pasture & 3 & $\mathrm{a}, \mathrm{s}$ & Klenk (2010) \\
\hline 39 & Atlantic Forest & Ponta Grossa - PR & Native vegetation & 2 & $\mathrm{a}, \mathrm{b}, \mathrm{s}$ & Ferreira (2015) \\
\hline 40 & Atlantic Forest & Ponta Grossa - PR & $\begin{array}{l}\text { IPS, forestry plantation, } \\
\text { crop, pasture }\end{array}$ & 5 & $\mathrm{a}, \mathrm{b}, \mathrm{s}$ & Zagatto (2014) \\
\hline 41 & Atlantic Forest & Ponta Grossa - PR & Crop & 4 & a & Voss (1986) \\
\hline 42 & Atlantic Forest & $\begin{array}{l}\text { Nova Aurora, Cafelândia, } \\
\text { Arapongas, Cascavel, Palotina - PR }\end{array}$ & Crop & 8 & $\mathrm{a}, \mathrm{b}, \mathrm{s}$ & $\begin{array}{l}\text { Lima et al. }(2008 / 2009) \text {; } \\
\text { Brown et al. }(2008)\end{array}$ \\
\hline 43 & Atlantic Forest & $\begin{array}{l}\text { Mercedes, Marechal Cândido } \\
\text { Rondon, Itaipulândia, Entre Rios do } \\
\text { Oeste, Santa Helena, Toledo - PR }\end{array}$ & Crop & 40 & $\mathrm{a}, \mathrm{b}, \mathrm{s}$ & Gorte (2016) \\
\hline 44 & Atlantic Forest & $\begin{array}{l}\text { Mercedes, Marechal Cândido Ron- } \\
\text {-don, Itaipulândia, Entre Rios do } \\
\text { Oeste, Santa Helena, Toledo - PR }\end{array}$ & $\begin{array}{l}\text { Crop, native vegetation, } \\
\text { forestry plantation }\end{array}$ & 29 & $\mathrm{a}, \mathrm{s}$ & $\begin{array}{l}\text { Bartz et al. (2010, } \\
\text { 2013) }\end{array}$ \\
\hline 45 & Atlantic Forest & Campos do Jordão - SP & $\begin{array}{l}\text { Native vegetation, forestry } \\
\text { plantation, IPS }\end{array}$ & 4 & $\mathrm{a}, \mathrm{b}, \mathrm{s}$ & $\begin{array}{l}\text { Baretta (2007); Baretta } \\
\text { et al. (2007) }\end{array}$ \\
\hline 46 & Atlantic Forest & Campos do Jordão - SP & $\begin{array}{l}\text { Native vegetation, forestry } \\
\text { plantation }\end{array}$ & 3 & $\mathrm{a}, \mathrm{s}$ & Merlim (2005) \\
\hline 47 & Atlantic Forest & São Roque - SP & Crop, native vegetation & 3 & $\mathrm{a}, \mathrm{s}$ & Uzêda et al. (2007) \\
\hline 48 & Atlantic Forest & Ubatuba - SP & Crop, pasture & 5 & $\mathrm{a}, \mathrm{s}$ & Marchiori (2008) \\
\hline 49 & Atlantic Forest & Duque de Caxias - RJ & Native vegetation & 2 & $\mathrm{a}, \mathrm{s}$ & Buch et al. (2015) \\
\hline 50 & Atlantic Forest & Itaboraí - RJ & Native vegetation & 6 & a & Ferreira et al. (2012) \\
\hline 51 & Atlantic Forest & Barra do Piraí - RJ & Forestry plantation & 4 & $\mathrm{a}, \mathrm{s}$ & $\begin{array}{l}\text { Bianchi (2009); } \\
\text { Correia et al. (2003) }\end{array}$ \\
\hline 52 & Atlantic Forest & Paty do Alferes, Valença - RJ & Native vegetation, crop & 12 & $\mathrm{a}, \mathrm{s}$ & $\begin{array}{l}\text { Pimentel (2005); } \\
\text { Pimentel et al. (2002, } \\
\text { 2011a) }\end{array}$ \\
\hline 53 & Atlantic Forest & Queluz - RJ & Native vegetation, pasture & 4 & $\mathrm{a}, \mathrm{s}$ & $\begin{array}{l}\text { Menezes (2008); } \\
\text { Menezes et al. (2009) }\end{array}$ \\
\hline 54 & Atlantic Forest & Seropédica - RJ & IPS, pasture & 4 & a & Dias et al. (2006b) \\
\hline
\end{tabular}

Continuation... 
Continuation...

\begin{tabular}{|c|c|c|c|c|c|c|}
\hline Study & Biome & Municipality - State & Land use system ${ }^{(1)}$ & Number $^{(2)}$ & $\operatorname{Data}^{(3)}$ & Reference \\
\hline 55 & Atlantic Forest & Seropédica - RJ & IPS, pasture & 6 & $\mathrm{a}$ & $\begin{array}{l}\text { Dias et al. (2007); } \\
\text { Silva et al. (2015a) }\end{array}$ \\
\hline 56 & Atlantic Forest & Seropédica - RJ & Crop & 3 & $\mathrm{a}, \mathrm{s}$ & Merlim et al. (2005) \\
\hline 57 & Atlantic Forest & Seropédica - RJ & Crop & 5 & $a, b$ & Rodrigues et al. (2004) \\
\hline 58 & Atlantic Forest & Seropédica - RJ & Crop & 5 & $\mathrm{a}$ & Cordeiro et al. (2004) \\
\hline 59 & Atlantic Forest & Nova Friburgo, Seropédica - RJ & Crop & 7 & a & Aquino et al. (2005) \\
\hline 60 & Atlantic Forest & Linhares - ES & Crop & 4 & $\mathrm{a}, \mathrm{s}$ & Benazzi (2011) \\
\hline 61 & Atlantic Forest & Alagoa, Bocaina de Minas - MG & $\begin{array}{l}\text { IPS, pasture, native veg- } \\
\text { etation }\end{array}$ & 6 & $\mathrm{a}, \mathrm{b}, \mathrm{s}$ & $\begin{array}{l}\text { Camargo (2016); } \\
\text { Camargo et al. (2015) }\end{array}$ \\
\hline 62 & Atlantic Forest & Araponga $-\mathrm{MG}$ & Crop, native vegetation & 8 & $\mathrm{a}, \mathrm{s}$ & Souza (2010) \\
\hline 63 & Atlantic Forest & Campos Gerais - MG & $\begin{array}{l}\text { Crop, native vegetation, } \\
\text { forestry plantation }\end{array}$ & 3 & a & $\begin{array}{l}\text { Marques \& Silva } \\
\text { (2011) }\end{array}$ \\
\hline 64 & Atlantic Forest & Governador Valadares - MG & Native vegetation, pasture & 2 & a & Vicente et al. (2010) \\
\hline 65 & Atlantic Forest & Ouro Fino - MG & Native vegetation, crop & 3 & $\mathrm{a}$ & Silva et al. (2014) \\
\hline 66 & Atlantic Forest & Pedralva - MG & Crop & 3 & $\mathrm{a}, \mathrm{s}$ & $\begin{array}{l}\text { Madeira et al. (2011); } \\
\text { Oliveira (2012) }\end{array}$ \\
\hline 67 & Atlantic Forest & Fátima do Sul - MS & Crop, native vegetation & 5 & $\mathrm{a}, \mathrm{s}$ & Silva et al. (2007) \\
\hline 68 & Atlantic Forest & Fátima do Sul - MS & Crop, native vegetation & 3 & $\mathrm{a}, \mathrm{s}$ & Silva et al. (2001) \\
\hline 69 & Atlantic Forest & Fátima do Sul - MS & Crop, native vegetation & 3 & $\mathrm{a}, \mathrm{s}$ & Otsubo et al. (2002) \\
\hline 70 & Atlantic Forest & Dourados - MS & $\begin{array}{l}\text { Crop, pasture, native } \\
\text { vegetation, IPS }\end{array}$ & 5 & $\mathrm{a}, \mathrm{s}$ & Silva et al. (2006) \\
\hline 71 & Atlantic Forest & Dourados - MS & $\begin{array}{l}\text { Crop, pasture, native } \\
\text { vegetation, IPS }\end{array}$ & 9 & $\mathrm{a}, \mathrm{s}$ & Portilho et al. (2011) \\
\hline 72 & Atlantic Forest & Itaporã - MS & Crop & 2 & $\mathrm{a}$ & Pezarico et al. (2006) \\
\hline 73 & Atlantic Forest & Selvíria-MS & $\begin{array}{l}\text { Native vegetation, forestry } \\
\text { plantation, IPS }\end{array}$ & 6 & $\mathrm{a}, \mathrm{s}$ & Marchini et al. (2011) \\
\hline 74 & Atlantic Forest & Cruz das Almas - BA & $\begin{array}{l}\text { Crop, Native vegetation, } \\
\text { IPS, Forest-ry plantation }\end{array}$ & 5 & $\mathrm{a}$ & Pereira et al. (2012) \\
\hline 75 & Atlantic Forest & João Pessoa, Areia - PB & IPS, native vegetation & 3 & $\mathrm{a}, \mathrm{b}, \mathrm{s}$ & Guerra \& Silva (1994) \\
\hline 76 & Pantanal & Aquidauana-MS & Native vegetation, crop & 4 & $\mathrm{a}, \mathrm{s}$ & Brito et al. (2016) \\
\hline 77 & Pantanal & Corumbá - MS & Native vegetation & 3 & a & Dias et al. (2006a) \\
\hline 78 & Cerrado & Brasília - DF & $\begin{array}{l}\text { Native vegetation, pasture, } \\
\text { IPS, crop }\end{array}$ & 14 & $\mathrm{a}, \mathrm{s}$ & Marchão et al. (2009) \\
\hline 79 & Cerrado & Brasília - DF & Native vegetation & 5 & $\mathrm{a}, \mathrm{b}, \mathrm{s}$ & Dias et al. (1997) \\
\hline 80 & Cerrado & Brasília - DF & Native vegetation & 2 & $\mathrm{a}, \mathrm{s}$ & $\begin{array}{l}\text { Bento (2009); Corrêa } \\
\& \text { Bento (2010) }\end{array}$ \\
\hline 81 & Cerrado & Correntina - BA & $\begin{array}{l}\text { Crop, pasture, native } \\
\text { vegetation }\end{array}$ & 6 & $\mathrm{a}, \mathrm{s}$ & $\begin{array}{l}\text { Marchão et al. (2008a, } \\
\text { 2008b) }\end{array}$ \\
\hline 82 & Cerrado & $\begin{array}{c}\text { Formosa - DF, Santo Antônio do } \\
\text { Descoberto - GO }\end{array}$ & Pasture & 4 & $\mathrm{a}, \mathrm{s}$ & $\begin{array}{l}\text { Vendrame (2008); } \\
\text { Vendrame et al. (2009) }\end{array}$ \\
\hline 83 & Cerrado & Jataí - GO & Native vegetation, crop & 7 & $\mathrm{a}, \mathrm{s}$ & Blanchart et al. (2007) \\
\hline 84 & Cerrado & Planaltina - GO & Native vegetation, pasture & 5 & $\mathrm{a}, \mathrm{b}$ & Benito et al. (2000) \\
\hline 85 & Cerrado & Santo Antônio de Goiás - GO & Crop, IPS & 8 & $\mathrm{a}, \mathrm{s}$ & Santos et al. (2008) \\
\hline 86 & Cerrado & Maracaju-MS & Native vegetation, IPS & 4 & $\mathrm{a}, \mathrm{s}$ & $\begin{array}{l}\text { Batista (2011); Batista } \\
\text { et al. (2014) }\end{array}$ \\
\hline
\end{tabular}

Continuation... 
Continuation...

\begin{tabular}{|c|c|c|c|c|c|c|}
\hline Study & Biome & Municipality - State & Land use system ${ }^{(1)}$ & Number $^{(2)}$ & $\operatorname{Data}^{(3)}$ & Reference \\
\hline 87 & Cerrado & Maracaju-MS & $\begin{array}{c}\text { Crop, pasture, IPS, } \\
\text { forestry plantation, native } \\
\text { vegetation }\end{array}$ & 6 & $\mathrm{a}, \mathrm{s}$ & Lourente et al. (2007) \\
\hline 88 & Cerrado & $\begin{array}{c}\text { Miranda-MS, } \\
\text { Rio Brilhante - MS }\end{array}$ & Crop & 2 & a & Barrigossi et al. (2009) \\
\hline 89 & Cerrado & São Carlos - SP & Pasture, native vegetation & 3 & $\mathrm{a}, \mathrm{s}$ & Brigante (2000) \\
\hline 90 & Cerrado & São José do Rio Preto - SP & Native vegetation & 1 & a & Caballero (1976) \\
\hline 91 & Cerrado & Taciba $-\mathrm{SP}$ & Crop, pasture & 3 & $\mathrm{a}, \mathrm{b}$ & Brown \& James (2007) \\
\hline 92 & $\begin{array}{l}\text { Cerrado, Atlantic } \\
\text { Forest }\end{array}$ & $\begin{array}{c}\text { Valparaíso, Ipaussu - SP, } \\
\text { Jataí - GO }\end{array}$ & $\begin{array}{l}\text { Crop, pasture, native } \\
\text { vegetation }\end{array}$ & 9 & $\mathrm{a}, \mathrm{s}$ & Franco et al. (2016) \\
\hline 93 & Cerrado & São Sebastião do Paraíso - MG & Crop & 2 & $\mathrm{a}, \mathrm{b}, \mathrm{s}$ & $\begin{array}{l}\text { Aquino et al. (2000); } \\
\text { Ricci et al. (1999) }\end{array}$ \\
\hline 94 & Cerrado & Uberlândia - MG & $\begin{array}{l}\text { Crop, pasture, native } \\
\text { vegetation }\end{array}$ & 5 & $\mathrm{a}, \mathrm{b}, \mathrm{s}$ & $\begin{array}{l}\text { Brossard et al. (2012); } \\
\text { Pasini et al. (2003) }\end{array}$ \\
\hline 95 & Cerrado & Uruçui - PI & Crop, native vegetation & 3 & a & Santos et al. (2013) \\
\hline 96 & Amazon & $\begin{array}{l}\text { Vila Bela da Santíssima } \\
\text { Trindade - MT }\end{array}$ & IPS & 2 & $\mathrm{a}, \mathrm{s}$ & Mendes et al. (2010) \\
\hline 97 & Amazon & Alcântara - MA & Native vegetation & 8 & $\mathrm{a}$ & Triana (2014) \\
\hline 98 & Amazon & São Luís - MA & IPS & 6 & $\mathrm{a}, \mathrm{s}$ & Moura et al. (2015) \\
\hline 99 & Amazon & Igarapé-Açu - PA & $\begin{array}{l}\text { Pasture, IPS, native } \\
\text { vegetation }\end{array}$ & 6 & a & Rousseau et al. (2010) \\
\hline 100 & Amazon & Itupiranga - PA & $\begin{array}{l}\text { Pasture, forestry planta- } \\
\text { tion, IPS }\end{array}$ & 16 & $\mathrm{a}, \mathrm{s}$ & $\begin{array}{l}\text { Laossi et al. (2008); } \\
\text { Velásquez et al. (2012) }\end{array}$ \\
\hline 101 & Amazon & São Félix do Xingu - PA & $\begin{array}{c}\text { Native vegetation, pasture, } \\
\text { IPS }\end{array}$ & 5 & $\mathrm{a}, \mathrm{s}$ & Braga (2015) \\
\hline 102 & Amazon & Benjamin Constant - AM & Native vegetation, pasture & 3 & $\mathrm{a}, \mathrm{b}, \mathrm{s}$ & Alves (2010) \\
\hline 103 & Amazon & Manaus - AM & $\begin{array}{l}\text { Native vegetation, forestry } \\
\text { plantation }\end{array}$ & 6 & $\mathrm{a}, \mathrm{s}$ & $\begin{array}{l}\text { Bandeira \& Harada } \\
\text { (1998); Harada \& } \\
\text { Bandeira (1994) }\end{array}$ \\
\hline 104 & Amazon & Manaus - AM & Native vegetation & 4 & a & $\begin{array}{l}\text { Araújo \& Luizão } \\
\text { (2011) }\end{array}$ \\
\hline 105 & Amazon & Manaus - AM & Crop, pasture & 4 & $\mathrm{a}, \mathrm{b}, \mathrm{s}$ & Pontes (2009) \\
\hline 106 & Amazon & Manaus - AM & Native vegetation & 6 & $\mathrm{a}, \mathrm{b}$ & $\begin{array}{l}\text { Lins-Teixeira et al. } \\
(2007)\end{array}$ \\
\hline 107 & Amazon & Presidente Figueiredo - AM & $\begin{array}{l}\text { Native vegetation, forestry } \\
\text { plantation }\end{array}$ & 4 & $\mathrm{a}, \mathrm{s}$ & Viana (2012) \\
\hline 108 & Amazon & Rio Preto da Eva-AM & IPS & 10 & $\mathrm{a}, \mathrm{b}$ & $\begin{array}{l}\text { Tarrá (2003); Tarrá et } \\
\text { al. (2012) }\end{array}$ \\
\hline 109 & Amazon & Rio Preto da Eva - AM & IPS, native vegetation & 5 & $\mathrm{a}, \mathrm{b}, \mathrm{s}$ & Barros et al. (2003) \\
\hline 110 & Amazon & $\begin{array}{l}\text { Rio Preto da Eva - AM, } \\
\text { Itapiranga - AM }\end{array}$ & $\begin{array}{c}\text { Native vegetation, pasture, } \\
\text { IPS }\end{array}$ & 3 & $\mathrm{a}, \mathrm{b}, \mathrm{s}$ & Barros et al. (1996) \\
\hline 111 & Amazon & Bonfim - RR & Native vegetation & 3 & $\mathrm{a}, \mathrm{b}$ & Guerra (1994a) \\
\hline 112 & Amazon & Cantá - RR & $\begin{array}{l}\text { IPS, native vegetation, } \\
\text { pasture }\end{array}$ & 6 & $\mathrm{a}$ & Costa et al. (2004) \\
\hline 113 & Amazon & Macapá - AP & Crop & 4 & $\mathrm{a}, \mathrm{b}, \mathrm{s}$ & Silva (2009) \\
\hline 114 & Amazon & Ji-Paraná - RO & IPS & 1 & $\mathrm{a}$ & Pequeno et al. (2005) \\
\hline 115 & Amazon & Nova Califórnia - RO & IPS, native vegetation & 4 & $\mathrm{a}, \mathrm{s}$ & Luizão et al. (2002) \\
\hline
\end{tabular}

Continuation... 
Continuation...

\begin{tabular}{|c|c|c|c|c|c|c|}
\hline Study & Biome & Municipality - State & Land use system $^{(1)}$ & Number $^{(2)}$ & $\operatorname{Data}^{(3)}$ & Reference \\
\hline 116 & Amazon & Ouro Preto do Oeste - RO & IPS & 3 & $\mathrm{a}$ & Silva et al. (2005) \\
\hline 117 & Amazon & Rio Branco - AC & Pasture, native vegetation & 2 & $\mathrm{a}, \mathrm{b}, \mathrm{s}$ & Guerra (1994b) \\
\hline 118 & Amazon & $\begin{array}{c}\text { Theobroma, Porto Velho, Ji-Paraná } \\
\text { - RO, Acrelândia - AC }\end{array}$ & $\begin{array}{l}\text { Native vegetation, crop, } \\
\text { IPS, pasture }\end{array}$ & 15 & $\mathrm{a}, \mathrm{b}, \mathrm{s}$ & Barros et al. (2002) \\
\hline 119 & $\begin{array}{l}\text { Amazon, Cer- } \\
\text { rado, Atlantic } \\
\text { Forest }\end{array}$ & $\begin{array}{l}\text { Itapuã do Oeste - RO, Uruará - PA, } \\
\text { Botucatu - SP, São Paulo - SP }\end{array}$ & $\begin{array}{l}\text { Native vegetation, pasture, } \\
\text { IPS }\end{array}$ & 11 & a & Catanozi (2010) \\
\hline 120 & Caatinga & Crato - CE & Native vegetation & 5 & $\mathrm{a}, \mathrm{s}$ & Araújo (2010) \\
\hline 121 & Caatinga & Esperantina - PI & $\begin{array}{l}\text { IPS, native vegetation, } \\
\text { crop }\end{array}$ & 5 & $\mathrm{a}, \mathrm{s}$ & $\begin{array}{l}\text { Lima (2008); Lima et } \\
\text { al. (2010) }\end{array}$ \\
\hline 122 & Caatinga & Bom Jesus - PI & $\begin{array}{l}\text { Native vegetation, crop, } \\
\text { pasture }\end{array}$ & 6 & $\mathrm{a}, \mathrm{s}$ & Santos et al. (2017) \\
\hline 123 & Caatinga & Juazeiro - BA & Crop & 1 & $\mathrm{a}, \mathrm{s}$ & Pimentel et al. (2011b) \\
\hline \multirow[t]{2}{*}{124} & Caatinga & Tauá - CE & Crop & 9 & $\mathrm{a}, \mathrm{s}$ & Lima et al. (2007) \\
\hline & 6 biomes $^{(4)}$ & 135 municipalities $^{(5)}$ & Number by category ${ }^{(6)}$ & & & Number by category ${ }^{(7)}$ \\
\hline Total & $\begin{array}{c}\text { Atlantic } \\
\text { Forest (73), } \\
\text { Pantanal (2), } \\
\text { Cerrado (21), } \\
\text { Amazon (24), } \\
\text { Caatinga (4), } \\
\text { and Pampa (5) }\end{array}$ & $\begin{array}{c}\text { DF, ES, MT, AP (1); } \\
\text { AC, MA, PB, RR, CE (2); } \\
\text { BA, PI (3); PA (4); } \\
\text { AM, GO (5); RO, SC (6); } \\
\text { RS (5); RJ (8); MG, MS (9); } \\
\text { SP (11); PR (47) }\end{array}$ & $\begin{array}{c}\text { Crop }(70 / 322) \\
\text { Native vegetation }(82 / 214) \\
\text { IPS }(32 / 101) \\
\text { Pasture }(40 / 87) \\
\text { Forestry plantation }(17 / 41)\end{array}$ & 765 sites & $\begin{array}{l}\mathrm{a}(124) \\
\mathrm{b}(42) \\
\mathrm{s}(83)\end{array}$ & $\begin{array}{l}\text { Papers in journal (49) } \\
\text { Book chapters (7) } \\
\text { Theses and disserta- } \\
\text { tions (36) } \\
\text { Abstracts/conference } \\
\text { papers/others (42) }\end{array}$ \\
\hline
\end{tabular}

(1)IPS, integrated production system, which includes different species. ${ }^{(2)}$ Number of sampling sites. ${ }^{(3)}$ a, abundance; b, biomass; and s, soil attributes, even if partial, chemical, and/or physical. ${ }^{(4)}$ The number between parentheses represents the total number of studies that were carried out in each biome. ${ }^{(5)}$ The number between parentheses represents the total number of studies that were carried out in each municipality in different Brazilian states. ${ }^{(6)}$ The numbers between parentheses represent the total number of studies/number of cases in the database. ${ }^{(7)}$ The sum of all studies in each category is greater than 124, because data from some studies were published in more than one format (e.g., thesis, paper, and other). Brazilian states: RS, Rio Grande do Sul; SC, Santa Catarina; PR, Paraná; SP, São Paulo; RJ, Rio de Janeiro; ES, Espírito Santo; MG, Minas Gerais; MS, Mato Grosso do Sul; BA, Bahia; PB, Paraíba; DF, Distrito Federal; GO, Goiânia; PI, Piauí; MT, Mato Grosso; MA, Maranhão; PA, Pará; AM, Amazonas; RR, Roraima; AP, Amapá; RO, Rondônia; AC, Acre; and CE, Ceará.

management practices adopted at the sites, and various soil and earthworm sampling-related variables.

\section{Geographic representation of the studies}

The 124 evaluated publications showed earthworm abundance for 765 sites throughout Brazil (Figure 2), the majority located in the Atlantic Forest biome $(64 \%$ of the total), with a much smaller proportion in the Amazon (17\%), Cerrado (12\%), Pampa (3\%), Caatinga (3\%), and Pantanal (1\%). As most Brazilian researchers work in the Atlantic Forest, considered a biodiversity hot spot (Myers et al., 2000) with 144 known earthworm species (Brown \& James, 2007), it is not surprising that most samples were collected from this biome (Table 1), specifically from sites ranging from the state of Rio Grande do Sul (seven studies in seven municipalities), in Southern Brazil, to the state of Paraíba in the Northeast (only one study in two municipalities) (Guerra \& Silva, 1994). Paraná was the best assessed state, comprising $38 \%$ of all studies, which were performed in 47 municipalities. Of the three states exclusively in the Atlantic Forest biome, i.e., Espírito Santo, Rio de Janeiro, and Santa Catarina, the former requires much more attention because there is scant information on earthworms from this state (Brown \& James, 2007), with only one known study in one municipality until now (Figure 2). The states from Northeastern Brazil were generally little represented in the publications. In fact, several states in this region - Pernambuco, Rio Grande do Norte, Sergipe, and Alagoas - have no quantitative data on earthworm populations. Another state with 
notoriously few records on earthworms (Brown \& James, 2007) and with no quantitative sampling is Tocantins. Clearly, sampling efforts in these states are urgently needed in order to reduce the knowledge gap on earthworm ecology and distribution in the country.
Only four studies examined the Caatinga and two the Pantanal (Table 1), revealing the lack of earthworm research in these biomes that occupy approximately 10 and $1.8 \%$ of Brazil's surface area, respectively (IBGE, 2019). Although only three species of earthworms

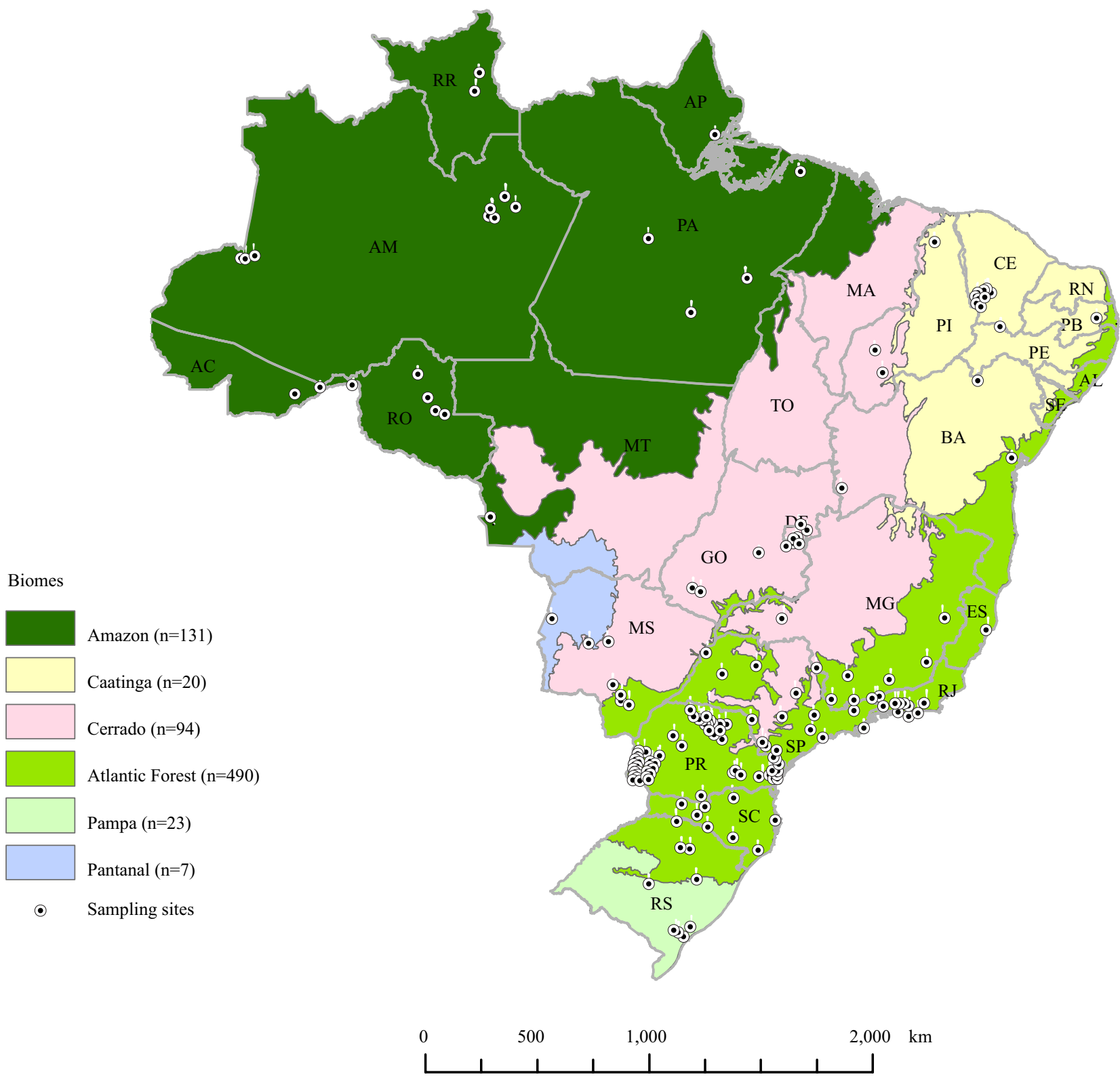

Figure 2. Geographic distribution and number of earthworm sampling sites in each Brazilian biome. Brazilian states: RO, Rôndonia; AC, Acre; AM, Amazonas; RR, Roraima; PA, Pará; AP, Amapá; MA, Maranhão; PI, Piauí; CE, Ceará; RN, Rio Grande do Norte; PB, Paraíba; PE, Pernambuco; AL, Alagoas; SE, Sergipe; BA, Bahia; ES, Espírito Santo; RJ, Rio de Janeiro; SP, São Paulo; PR, Paraná; SC, Santa Catarina; RS, Rio Grande do Sul; MS, Mato Grosso do Sul; MT, Mato Grosso; TO, Tocantins; GO, Goiânia; DF, Distrito Federal; and MG, Minas Gerais. 
from the Caatinga are known (Brown \& James, 2007), there are records of large and very active earthworms in this biome (Cordero, 1943; Almeida et al., 2009), and clayey soils and/or those with a higher potential to maintain moisture can harbor earthworm population densities of over 100 individuals per square meter (Araújo et al., 2010; Lima et al., 2010). In the Caatinga, earthworms are subjected to a higher seasonal variation and to a lower precipitation than in other locations in the country, which causes them to undergo diapause or prolonged inactivity, generally at greater soil depths (Silva et al., 2015b). Therefore, future sampling in this biome should seek to better understand the climatic and edaphic limitations to earthworm populations, also taking into account the time of year for sampling, prioritizing the rainy season, when the soil is moister and the earthworms are active and closer to the surface. In two sites in the Caatinga, earthworms were found only in samples collected in the rainy season (Araújo et al., 2010; Lima et al., 2010).

In the Pantanal, where climate seasonality is also important, the yearly flooding of vast areas may cause difficulties, both for the sampling of earthworms and of their activity in the soil. Currently only 18 earthworm species from this biome are known, and some of them are well adapted to living in flooded soils (Carter \& Beadle, 1931; Brown \& James, 2007). The data of the two studies carried out in this biome (Table 1 and Figure 2) showed that the earthworm populations there had a high density in native vegetation (Dias et al., 2006a), but a very low abundance under cassava (Manihot esculenta Crantz) crops (Brito et al., 2016). Unfortunately, the earthworm species were not identified, but it is known that flooded areas, including rice (Oryza sativa L.) plantations (Barrigossi et al., 2009; Bartz et al., 2009b), can harbor a significant numbers of native species, especially of the Ocnerodrilidae and Almidae families (Brown \& James, 2007). Therefore, future sampling in this biome should consider the particularities of each region and its earthworm species, adapting the methodology to the local conditions.

In the Pampa biome, which occupies $2 \%$ of Brazil's territory, only five studies evaluated earthworm populations (Table 1) in the regions of Santa Maria and Pelotas, in the state of Rio Grande do Sul (Figure 2). From this biome, 36 earthworm species are known, but $70 \%$ of them are exotic, i.e., non-native species, originally from other countries (Brown \& James, 2007). The predominant $C$ fa climate in this biome has no defined dry season (Alvares et al., 2013), which allows earthworms to be active all year, even during winter, at very low ambient temperatures of $-4^{\circ} \mathrm{C}$ (Santos et al., 2019), since the soil does not freeze.

In the Cerrado biome, another biodiversity hotspot (Myers et al., 2000) that covers $24 \%$ of Brazil (IBGE, 2019), 20 studies assessed earthworm populations. Although termites and ants predominate in this biome (Benito et al., 2004; Marchão et al., 2009), earthworm populations can have a considerable abundance and biomass in certain locations, mainly in pastures or integrated production systems (Brigante, 2000; Brown \& James, 2007; Marchão et al., 2009), but also in coffee (Coffea arabica L.) plantations (Ricci et al., 1999) and under no-tillage agriculture (Blanchart et al., 2007). However, native Cerrado vegetation tends to have very few earthworms, especially in Central Brazil (Benito et al., 2008; Dias et al., 1997). Sampling time in this biome is especially important, because soils tend to be very dry and hard in winter, making it difficult to collect earthworms, which undergo diapause or aestivation (Abe \& Buck, 1985; Silva et al., 2015b), normally in deeper layers.

In the Amazon, earthworm populations were reported in 24 publications (19\% of the total). However, greater efforts are needed to better understand earthworm populations in this biome and the possible impacts of human activities, considering the region's size, the large variation in vegetation, soils, and natural and humanaltered environments in this biome, and the high diversity of earthworm species in the Amazon Basin (Lavelle \& Lapied, 2003). In addition, the presence of earthworms is high in this biome: no earthworms ( 0 individual per square meter) were reported only in five cases (3.5\%), in dense Ombrophylous forest (Silva et al., 2005; Catanozi, 2010; Viana, 2012), and in corn (Zea mays L.) (Moura et al., 2015) and coffee (Silva et al., 2005) plantations.

Clearly, sampling efforts in the different Brazilian biomes have been highly variable (Figure 2). Furthemore, the specificities of each biome in terms of soils, vegetation, climate, and earthworm species present must be taken into account in order to optimize sampling schemes. Moreover, the data presented here can be used to target or prioritize future sampling sites and regions, in order to improve the understanding of 
earthworm communities in different ecosystems and their role in soil processes.

\section{Climate and vegetation-related variables}

Only three variables were considered by all authors: municipality, state, and soil cover/main vegetation type; other attributes that are easily available or that can be easily determined were often not included. The absence of these data, particularly sampling date (provided in $93 \%$ of the studies), sampling season (in $37 \%$ ), geographical coordinates (in $65 \%$ ), or the name of the specific location (in 74\%), complicates data interpretation and comparison. Since climatic and vegetation-related variables are key determinants of earthworm biodiversity and activity in soils, their adequate reporting is crucial to correctly identify the context in which the data on earthworm communities was collected and to interpret the obtained results (Lavelle et al., 1993; Brown \& Domínguez, 2010; Phillips et al., 2019).

A total of 13 climate and vegetation-related variables were identified and selected from the evaluated studies (Table 2). Climate is among the environmental attributes considered most important for earthworms (Phillips et al., 2019), regulating annual average temperature and precipitation and, consequently, driving soil moisture (Lavelle \& Spain, 2001; Blume et al., 2016; Rutgers et al., 2016).

Altitude influences climate, especially temperature, and the type of vegetation, which affect soil and litter quantity and quality at the collection sites; therefore, it can have an important impact on earthworm abundance and species composition (Cardoso et al., 2014). Climaterelated variables are also fundamental to determine the best assessing season (dry or rainy) and if the weather, particularly rainfall regime and potential soil moisture, is favorable for sampling earthworm activity and abundance (Satchell, 1967; Lavelle, 1983; Kale \& Karmegam, 2010). Due to the high seasonal variability in earthworm abundance (Nadolny, 2017), especially in seasonally dry climates, the earthworm population should be assessed preferably towards the end of the rainy season, when most of the individuals have reached the adult stage (Lavelle, 1983), facilitating their identification (Richard et al., 2010).

Of the 12 climatic types described in Brazil (Alvares et al., 2013), only 9 were represented in the publications
(Nadolny et al., 2020). Climate at the sampling site - the main factor affecting earthworms in most population models (Phillips et al., 2019; Lavelle et al., 1993 ) - was omitted in $46 \%$ of the studies, although approximately $60 \%$ of them included information on precipitation and temperature. Even though climate data can be derived from the collection site using GPS coordinates and climate-specific databases, information on particular climate conditions during or just prior to sampling (e.g., large rainfall events) are crucial to better understand the results obtained for the earthworm community (Satchell, 1967).

Less than half $(42 \%)$ of the studies described the biome and only $44 \%$ described the native vegetation of the sampling site (Table 2). Although this information can be easily obtained from other sources, more detail on the conditions of the vegetation are always a fundamental factor for assessing earthworm communities, since well-preserved or primary vegetation are more likely to have native species than secondary forests or highly disturbed sites (Brown \& James, 2007). In addition, the age of regeneration of the vegetation can also have a key impact on earthworm abundance (Rousseau et al., 2014). Therefore, knowledge on the vegetation at the experimental sites is especially important because it allows determining the amount, type, and quality of the organic matter inputs made available both above- and belowground for earthworm consumption (Curry, 2004).

\section{Management-related variables}

Eight management-related variables were identified and selected from the evaluated studies (Table 2). Human disturbance and soil management practices have major impacts on earthworm communities in Brazil (Brown \& James, 2007; Nadolny, 2017) and were addressed in the majority of the studies included in the database (Nadolny et al., 2020). However, reporting of management practices and land use history in the publications was highly variable. Current and former land use are important variables in determining earthworm populations, and information on both should be provided in earthworm sampling schemes. In this regard, the number of years in current land use was provided in $58 \%$ of the publications, i.e., for 410 sites, but only $28 \%$ of the authors indicated previous land use. 
Agricultural cropping was the most frequently assessed land use system (70 studies), representing 322 sites, i.e., $52 \%$ of all data (Table 1). Approximately half $(49 \%)$ of the studies also described the soil management systems and crop type at sampling time (Table 2). Information on the type of soil tillage is essential because conventional tillage can negatively affect earthworm populations, whereas no-tillage systems usually have positive effects (Briones \& Schmidt, 2017; Brown et al., 2003). Information on crop type and management is also important because these influence the amount and type of crop residues and their $\mathrm{C}: \mathrm{N}$ ratio, which determine the food value for earthworms. Low C:N materials tend to decompose faster and have a higher $\mathrm{N}$ content, one of the main components of earthworms $(11 \% \mathrm{~N}$ in dry matter), essential for their growth and reproduction (Huerta et al., 2005, 2007).

Integrated production systems - such as agroforestry, integrated crop-livestock (agropastoral), integrated crop-livestock-forestry (agrosilvopastoral), and livestock-forestry (silvopastoral) systems - were reported in 32 studies and represented $26 \%$ of the sampled sites (Table 1). Pastures and integrated production systems, like agropastoral and agrosilvopastoral systems, tend to be good for earthworms (Lourente et al., 2007; Franchini et al., 2009; Marchão et al., 2009; Batista et al., 2014) and generally have higher earthworm population densities than annual crops, particularly in the tropics (Decaëns

Table 2. Data on the overall environmental (except soil) and management-related variables collected in the literature review, number of studies (percentage of total in parentheses) with the information available, and number of samples included in the database $\left(\mathrm{N}^{\circ} \mathrm{db}\right)^{(1)}$.

\begin{tabular}{|c|c|c|c|}
\hline Variable & Description & $\mathrm{N}^{\circ}$ of studies $(\%)$ & № $\mathrm{db}$ \\
\hline \multicolumn{4}{|l|}{ Climate and vegetation-related } \\
\hline Sampling date & Month/year of sampling & $115(93)$ & 722 \\
\hline Sampling season & Specification of wet or dry season & $46(37)$ & 758 \\
\hline Location & Name of sampling site (such as farm and experimental field) & $92(74)$ & 587 \\
\hline Municipality & Name of municipality & $124(100)$ & 765 \\
\hline State & Acronym of the Brazilian state & $124(100)$ & 765 \\
\hline Geographical coordinates & $\begin{array}{l}\text { Coordinates of the collection site, preferably in degrees, minutes, and seconds, or } \\
\text { transformed to decimals }\end{array}$ & $80(65)$ & 765 \\
\hline Altitude & Altitude (meters) above sea level & $66(53)$ & 765 \\
\hline Annual mean precipitation & Annual mean precipitation in millimeters & $76(61)$ & 765 \\
\hline Annual mean temperature & Annual mean temperature in degree Celsius & $73(59)$ & 765 \\
\hline Köppen's climate & Climate type according to Köppen's classification & $66(53)$ & 765 \\
\hline Biome & Brazilian biome where sampling was done & $52(42)$ & 765 \\
\hline Soil cover/vegetation type & Soil cover or type of vegetation & $124(100)$ & 765 \\
\hline Type of native vegetation & Type of local native vegetation according to IBGE (2012) & $54(68)^{(2)}$ & 208 \\
\hline \multicolumn{4}{|l|}{ Management-related } \\
\hline Crop type & Name of crop at or just before sampling date & $65(98)^{(2)}$ & 284 \\
\hline Soil management & Soil disturbance (conventional seeding, minimum tillage, no-tillage, permanent crop) & $60(48)$ & 279 \\
\hline Current land use in years & Time in years of the soil in its current use & $72(58)$ & 410 \\
\hline Previous land use & Previous use of the soil in the area & $35(28)$ & 134 \\
\hline Pesticide use & Pesticide use (yes or no) & $7(6)$ & 20 \\
\hline Pesticide type & Insecticides, fungicides, and herbicides & $2(2)$ & 7 \\
\hline Fertilizers & Fertilizers applied (inorganic, organic, or none) & $65(52)$ & 215 \\
\hline Fertilizer type & Name of used fertilizers & $16(13)$ & 41 \\
\hline
\end{tabular}


et al., 2004; Nunes et al., 2007). Agroforestry systems are also beneficial to earthworm populations (Luizão et al., 2002; Brown et al., 2006b, 2009; Römbke et al., 2009; Tarrá et al., 2012; Tapia-Coral et al., 2015), not only due to the protection offered by the greater vegetation cover (trees), which affects soil temperature and humidity, but also due to the diversification in the sources of the organic matter added to the soil.

Forestry plantations represented only $16 \%$ of the sampling sites and were addressed in five studies, mostly $(77 \%)$ performed in sites located in Southern and Southeastern Brazil. Considering the area of 10 million ha that these plantations occupy in the country (IBGE, 2015) and their economic importance, greater sampling efforts are needed regarding forestry systems. Tree species and management affect both surface litter and underground organic matter quality, affecting the role of these systems as earthworm habitats. Higher $\mathrm{Ca}$ contents in the litter of some tree species can positively affect soil $\mathrm{pH}$ over time, influencing earthworm populations (Reich et al., 2005). The forestry species most common in Brazil are Eucalyptus and Pinus, both of which provide litter with low nutritional quality for earthworms (Bernhard-Reversat et al., 2001); however, large populations can still be found in these plantations (Maschio et al., 2014; Silva et al., 2019), where they may be providing important environmental services, like organic matter decomposition, nutrient cycling, and soil aggregation, a topic deserving further attention (Silva et al., 2019).

Besides soil disturbance, the use of pesticides and fertilizers at the sampling site(s) must also be known. However, only $5 \%$ of the studies recorded pesticide use in the sampling sites and just $2 \%$ revealed the type of product used. Moreover, only $13 \%$ of the studies mentioned fertilization, including chemical, organic, or mineral fertilizers, and just $10 \%$ detailed which types were applied. These management practices can deeply influence earthworm communities, since several pesticides cause reductions in the fecundity and changes in the feeding behavior and mortality of earthworms (Pelosi et al., 2014). However, little is known about the effects of most pesticides used in Brazilian agriculture on the earthworms actually present in the soils of the country (Sisinno et al., 2019). Some studies have reported that the application of fertilizers may increase earthworm densities because it also tends to increase plant production
(Edwards \& Lofty, 1982; Misra \& Tripathy, 1988), generally increasing the input of organic matter (food for earthworms) into the soil. For the same reasons, the application of manure-based organic fertilizers also tends to be beneficial to earthworm populations (Tiwari, 1993; Curry, 2004). Conversely, the prolonged use of large quantities of inorganic N-based fertilizers can cause soil acidification, which, if not corrected, may decrease earthworm abundance (Ma et al., 1990).

Therefore, soil and crop management practices have major impacts on the soil as a habitat for earthworms, with intense positive or negative effects (Curry, 2004), depending on the specific practice or on the combination of practices adopted. For this reason, standardizing the obtained data will provide important insights into possible mechanisms of population regulation in individual studies and future reviews on these topics.

\section{Soil-related variables}

In Brazil, the majority of the earthworm species belong to the endogeic ecological category, living in and feeding within the soil matrix, rarely coming out onto soil surface (Lavelle, 1988b; Brown \& James, 2007). Therefore, it is expected that soil type and physical and chemical attributes will affect their activity and populations in Brazilian ecosystems.

A total of 17 soil-related variables were selected from the publications and are listed in Table 3. Several studies in Brazil have highlighted the complex relationships between earthworm populations and some soil characteristics, particularly $\mathrm{pH}$, organic matter, $\mathrm{Ca}, \mathrm{Mg}, \mathrm{P}, \mathrm{Al}$, texture and bulk density (Brown et al., 2003; Silva, 2010; Lima, 2011; Baretta et al., 2013; Bartz et al., 2013). However, these relationships are difficult to establish, because earthworms inhabit a multivariate habitat, where several factors act and interact simultaneously, affecting the soil's potential as a habitat for the development and activity of earthworm populations.

The soil type of the sampling site was given in $80 \%$ of the studies. This factor is generally considered key for earthworm species, whose preferences vary in terms of soil texture, $\mathrm{pH}$, or organic matter content, all largely determined by the type of soil, whose properties also strongly influence the bioavailability of chemical stressors such as metals or pesticides (Ortega-Calvo

Pesq. agropec. bras., Brasília, v.55, e01006, 2020

DOI: 10.1590/S1678-3921.pab2020.v55.01006 
et al., 2015; Romero-Freire et al., 2015; Marchand et al., 2017). This shows that the classification of soils can provide useful information on their physical and chemical properties, water regime, depth and nutrient content, important to determine earthworm populations at a given site (Curry, 2004). However, little is known about the preference of earthworm species for soil types in Brazil - only one study on this topic has been performed so far, in the Cerrado region of northwestern São Paulo (Caballero, 1973, 1976). Furthermore, unfortunately, the soil maps available for most regions of Brazil are still at geographic scales too gross for the adequate estimation of the soil types at a collection site, indicating that more precise and, preferably, primary data on soil types should be provided.

Soil $\mathrm{pH}$ was informed in $56 \%$ of the evaluated studies (Table 3), being the most mentioned of all soil attributes. Most Brazilian soils are naturally acid (Motta \& Melo, 2009), so the earthworms living in them are generally adapted to acidic conditions. However, there is little information on the $\mathrm{pH}$ preferences of Brazilian earthworm species (Steffen, 2012), which may also vary depending on soil type. Some species of earthworms of the Lumbricidae family, which is typical of cooler regions with a temperate climate, show a clear preference for particular soil $\mathrm{pH}$ intervals (Satchell, 1967; Graefe \& Beylich, 2003), but only a few lumbricids actually inhabit Brazilian soils and those that do are all exotic and occur almost exclusively in the Southern region of the country (Brown et al., 2006a). The common invasive species Pontoscolex corethrurus, from the Rhinodrilidae family, the most widespread earthworm in Brazil (Brown et al., 2006a), inhabits soils with $\mathrm{pH}$ ranging from 4.5 to 6.2 (Knapper \& Porto, 1979; Steffen, 2012), while Amynthas spp. (Amynthas gracilis and Amynthas corticis) of the Megascolecidae family, also widely distributed in the country (Brown et al., 2006a), live in soils with higher $\mathrm{pH}$, ranging from 4.8 to 7.2 (Knapper \& Porto, 1979; Steffen, 2012). Soil $\mathrm{pH}$ also determines the availability of a number of other soil elements important for plant

Table 3. Soil-related variables, including soil type and chemical and physical parameters, identified in the literature review, number of studies (percentage of total in parentheses) with this information available, and number of samples included in the database (№ $\mathrm{db})^{(1)}$.

\begin{tabular}{|c|c|c|c|}
\hline Variable $^{(2)}$ & Description & № of studies (\%) & № $\mathrm{db}$ \\
\hline Soil type & $\begin{array}{l}\text { Soil classification according to the Brazilian classification system (Santos et } \\
\text { al., 2018) or to the Food and Agricultural Organization (FAO, 2015) }\end{array}$ & $99(80)$ & 765 \\
\hline $\mathrm{pH}$ & Soil $\mathrm{pH}$ in $\mathrm{CaCl}_{2}, \mathrm{KCl}$, or $\mathrm{H}_{2} \mathrm{O}$ ( $\mathrm{pH}$ in water transformed to $\mathrm{CaCl}_{2}$ ) & $70(56)$ & 438 \\
\hline $\mathrm{H}+\mathrm{Al}$ & Soil potential acidity $\left(\mathrm{cmol}_{\mathrm{c}} \mathrm{dm}^{-3}\right)$ & $39(31)$ & 277 \\
\hline K & Available potassium $\left(\mathrm{cmol}_{\mathrm{c}} \mathrm{dm}^{-3}\right)$ & $62(50)$ & 386 \\
\hline $\mathrm{Ca}$ & Available calcium $\left(\mathrm{cmol}_{\mathrm{c}} \mathrm{dm}^{-3}\right)$ & $59(48)$ & 360 \\
\hline $\mathrm{Mg}$ & Available magnesium $\left(\mathrm{cmol}_{\mathrm{c}} \mathrm{dm}^{-3}\right)$ & $59(48)$ & 360 \\
\hline $\mathrm{P}$ & Total phosphorus by Mehlich (mg dm $\left.{ }^{-3}\right)$ & $58(47)$ & 361 \\
\hline $\mathrm{C}$ & Total carbon by combustion or Walkley-Black $\left(\mathrm{g} \mathrm{dm}^{-3}\right)$ & $44(35)$ & 305 \\
\hline Sum of bases & Sum of bases $\left(\mathrm{cmol}_{\mathrm{c}} \mathrm{dm}^{-3}\right)$ & $41(33)$ & 386 \\
\hline CEC & Soil CEC $\left(\mathrm{cmol}_{\mathrm{c}} \mathrm{dm}^{-3}\right)$ & $42(34)$ & 320 \\
\hline Base saturation & Base saturation (\%) & $36(29)$ & 324 \\
\hline $\mathrm{N}$ & Total nitrogen by Kjeldahl or combustion $\left(\mathrm{g} \mathrm{dm}^{-3}\right)$ & $15(12)$ & 104 \\
\hline $\mathrm{C}: \mathrm{N}$ & Soil carbon:nitrogen ratio & $11(9)$ & 62 \\
\hline Sand & Total sand content $\left(\mathrm{g} \mathrm{kg}^{-1}\right)$ & $42(35)$ & 295 \\
\hline Clay & Clay content $\left(\mathrm{g} \mathrm{kg}^{-1}\right)$ & $48(39)$ & 319 \\
\hline Silt & Silt content $\left(\mathrm{g} \mathrm{kg}^{-1}\right)$ & $44(35)$ & 295 \\
\hline Textural class & Textural class according to IBGE (2007) & $55(44)$ & 423 \\
\hline
\end{tabular}

${ }^{(1)}$ Database available at Nadolny et al. (2020). ${ }^{(2)} \mathrm{CEC}$, cation exchange capacity. 
and animal life, especially bases, cation exchange capacity, and $\mathrm{Al}$ and $\mathrm{P}$ contents. In Brazil, liming is one of the most common agricultural and forestry practices to increase soil $\mathrm{pH}$, and can have profound effects on plant production and earthworm populations (Lavelle et al., 1995a). In many cases, liming is performed with calcium carbonate, increasing $\mathrm{Ca}$ availability in the soils.

Even though $\mathrm{Ca}$ is one of the most important elements to determine in a soil chemical analysis due to its direct relationship to $\mathrm{pH}$, its contents were reported in less than half $(48 \%)$ of the studies. The Ca content can be close to $1 \%$ dry mass in earthworms tissues (Paoletti et al., 2003), and this element plays a vital role in earthworm metabolism, being used to produce $\mathrm{CaCO}_{3}$ in the calciferous glands, reduce $\mathrm{CO}_{2}$ levels in the body, and regulate the $\mathrm{pH}$ of the gut (Piearce, 1972; Versteegh et al., 2014). In fact, the physiological activities involving $\mathrm{Ca}$ in earthworms are indicative of a mechanism of $\mathrm{C}$ sequestration in soils (Briones et al., 2008).

Data on the $\mathrm{K}$ and $\mathrm{Mg}$ cations in the soil were provided in approximately half (50 and $48 \%$, respectively) of the studies; however, soil potential acidity $(\mathrm{H}+\mathrm{Al})$, cation exchange capacity, base saturation, and sum of bases were rarely provided (29-34\%). These factors are generally well related to soil fertility levels (Ribeiro et al., 1999), and, therefore, commonly determined in soil quality assessments, especially in agricultural fields (Raij, 1987). However, the relationships between earthworm populations and the potential acidity, cation exchange capacity, base saturation, and $\mathrm{K}$ and $\mathrm{Mg}$ contents of the soils are not well known, particularly in Brazilian ecosystems.

Although soil $\mathrm{P}$ is generally tightly bound and is one of the most limiting elements in Brazilian soils (Malavolta, 2006), it was reported in only $47 \%$ of the studies. Therefore, there is still no clear relationship between $\mathrm{P}$ levels in the soil and earthworm populations, even though higher earthworm abundance has been associated with higher soil P contents (Bartz et al., 2013). It has also been shown that soil $P$ is important for the metabolism of earthworms, whose tissues contain about $0.5 \%$ P (Paoletti et al., 2003), and a unique phosphagen, called phospholombricine (Wilson et al., 1992).

Despite being well known to positively affect soil quality (Sparling et al., 2008) and fauna populations and activity (Lavelle et al., 2001), soil organic matter content is not always included in routine soil analyses in Brazil (Raij, 1987). Hence, only $34 \%$ of the studies provided soil $\mathrm{C}$ values (Table 3). Of these, some showed positive relationships between earthworm abundance and soil organic matter content (e.g., Brown et al., 2004), considered the main energy source for the earthworm metabolism (Martin et al., 1992). Endogeic earthworm species, the most common in Brazil, must ingest large amounts of soil due to their generally low $\mathrm{C}$ content and have also developed a mutualistic digestion system with bacteria in their gut to help them increase the assimilation of the ingested organic materials (Lavelle et al., 1995b).

Only $12 \%$ of the studies provided soil $\mathrm{N}$ values, probably because total $\mathrm{N}$ estimates are not included in routine soil analyses in Brazilian laboratories (Raij, 1987). Earthworm tissues have high proportions of N, in general about $70 \%$ protein in dry matter (Paoletti et al., 2003), even though the abundance of this element in the soil is low. Clearly, this is an essential element for earthworm populations in the soils, especially regarding their growth and reproduction; however, relationships between soil $\mathrm{N}$ and earthworms have not been frequently established (Huerta et al., 2005, 2007). Although the soil C:N ratio was evaluated in only 9\% of the studies, being the least reported soil variable, it may still be important for earthworm communities, since it was identified as one of the factors governing the distribution of earthworm species in German soils (Römbke et al., 2012).

Soil texture, particularly clay content, is a key factor for earthworm activity because it generally influences both soil C content and water retention in different pore sizes (Feller \& Beare, 1997; Costa et al., 2013). The preference of many lumbricid earthworm species for specific soil textural classes was studied by Guild (1948), who found that medium-textured soils appeared to be more favorable than sandy or clayey ones. More recently, Vendrame et al. (2009) observed that some earthworm species in the Cerrado preferred soils with high levels of kaolinite; however, very little information is available on the soil textural and mineralogical preferences of Brazilian species (Steffen, 2012). Soil textural classes were provided in $44 \%$ of the studies, and the specific contents of clay, sand, and silt were given in $35-39 \%$ of them. Stony or very coarse sandy soils may restrict earthworm populations (Guild, 1948), 
mainly because of their low water retention capacity, but also of the presence of sand quartz crystals that may damage the earthworm's epidermis (Curry, 2004). At the other end of the textural triangle, heavy clay soils have a higher tendency to compaction, which can hinder earthworm activity, reducing soil displacement and ingestion (Klok et al., 2007). Furthermore, clayey soils often have lower water infiltration rates, which can negatively affect water availability in the soil profile due to a higher runoff, reducing earthworm activity (Edwards \& Bohlen, 1996). Under more intense rainfall, these soils could become flooded, particularly in flatlands, complicating gas exchanges and earthworm respiration. However, most earthworms can survive short periods of anaerobiosis in case their burrows are flooded after heavy rains (Lee, 1985).

Soil moisture is an extremely important factor for the survival of earthworms (Lee, 1985; Edwards, 2004) - first, because their bodies are formed by $>80 \% \mathrm{H}_{2} \mathrm{O}$ (Caballero, 1979; Ayres \& Guerra, 1981) and, second, because they breathe through their skin, which needs to be kept continuously moist. However, this attribute was reported in only $17 \%$ of the evaluated publications. The ideal available water content for earthworms differs from one species to another and depends on the respective soil properties, especially texture and the amount of organic matter (Edwards \& Bohlen 1996). Therefore, gravimetric soil moisture measurements must be related to soil texture and compared with overall water holding capacity. Lavelle et al. (1987), for instance, found that the ideal soil moisture values for the optimum development of $P$. corethrurus were all well above the field capacity of $35 \% \mathrm{H}_{2} \mathrm{O}$ in a Mexican clayey loam soil, with $31 \%$ clay and $40 \%$ sand. Hydrophilic species, such as most representatives of the Ocnerodrilidae, Sparganophilidae, Almidae, and Criodrilidae families (Righi, 1997), as well as some members of the Glossoscolecidae, Rhinodrilidae, and Acanthodrilidae families (Ayres \& Guerra, 1981; Gavrilov, 1981; Barrion \& Litsinger, 1997; Bartz et al., 2012), live in saturated soils with a low oxygen pressure. For instance, 33 of the 40 species from Central Amazon were found only next to water bodies, while $10 \%$ were collected in upland sites, being presumably more resistant to soil moisture variations (Ayres \& Guerra, 1981). Unfortunately, very little is known regarding the soil moisture preferences of most Brazilian earthworm species, which is an indicative that this is another important topic for basic biology research on earthworms.

\section{Sampling and earthworm-related attributes}

The most widely used method of assessing earthworm abundance in tropical countries is handsorting, following the tropical soil biology and fertility (TSBF) method (Anderson \& Ingram, 1993), combined with formalin expulsion of large earthworms (Römbke et al., 2006). The TSBF method (ISO, 2018), originally devised by Lavelle (1988a), recommends digging and hand-sorting five to ten holes of $25 \times 25 \mathrm{~cm}$ width and $30 \mathrm{~cm}$ depth - $15 \mathrm{~cm}$ in ISO (2018) - in each area/ plot/treatment/site to be studied (Anderson \& Ingram, 1993). Although the method has some limitations, especially when collecting smaller individuals and cocoons (Lavelle et al., 1981; Jiménez et al., 2006), it has been widely used in the tropics and subtropics, with a reasonable success rate (Rossi et al., 2006). All publications selected for this review applied this method or adaptations of it (Nadolny et al., 2020), which included digging shallower $(10 \mathrm{~cm})$ or deeper $(40 \mathrm{~cm})$ holes, increasing the size of the holes $(40 \times 40$ $\mathrm{cm})$, and increasing $(\mathrm{n}=36$ holes) or decreasing $(\mathrm{n}=3)$ sample frequency number.

Most studies (73\%) used standard sizes of $25 \times 25$ $\mathrm{cm}$ or smaller for the sampling holes (Nadolny et al., 2020). The main limitation to smaller holes is that larger-sized earthworms are frequently cut and, therefore, not adequately sampled. To avoid this, when adult earthworms larger than $12.5 \mathrm{~cm}$, i.e., half the width, are present, wider holes of $30 \times 30$ or $40 \times 40 \mathrm{~cm}$ should be dug to reduce earthworm amputation. If there are only small earthworms with mean lengths of $5-10 \mathrm{~cm}$, such as the size of $P$. corethrurus, then the standard hole of $25 \times 25 \mathrm{~cm}$ is suitable. If anecic or large-bodied earthworms - which form casts and open burrows on the soil surface and usually respond to chemical extractants - are present at the site, then sampling should follow the ISO (2018) norm. This consists of hand-sorting soil from holes $50 \times 50 \mathrm{~cm}$ wide and $20 \mathrm{~cm}$ deep, and posteriorly applying 5 to $10 \mathrm{~L}$ of the chemical extractant AITC, at the concentration of $0.1 \mathrm{~g} \mathrm{~L}^{-1}$; if giant earthworms, greater than $50 \mathrm{~cm}$ in length, are present, then the sampling area should be expanded to $4 \mathrm{~m}^{2}$ and $80 \mathrm{~L}$ AITC should be applied (Römbke, 2007; ISO, 2018). AITC replaced formalin 
as the recommended chemical extractant in the latest ISO norm (ISO, 2018), due the possible carcinogenic properties of formalin. However, only one study has tested the efficiency of AITC in Brazil (Ressetti et al., 2008), which was higher than formalin in cropping systems, but lower in pasture and native forest. Therefore, further research is needed to evaluate the adoption of AITC as the recommended chemical extractant in the country.

There is little published information on the ideal size of soil monoliths for quantitative earthworm sampling. Two Brazilian studies (Baretta et al., 2007; Cardoso et al., 2014) found that $40 \times 40$ or $50 \times 50-\mathrm{cm}$ wide holes were better than the standard TSBF-sized holes of $25 \times 25 \mathrm{~cm}$ for collecting worms, probably because the experimental sites had large or fast-moving species. Caballero (1976) tested many hole sizes and proposed that the $50 \times 50$ or $60 \times 60-\mathrm{cm}$ dimensions were the best for her research conditions, that included large earthworm species. However, due to the size of these holes, more effort and time was needed to dig and handsort the soil from them, making it a procedure difficult or impossible to adopt in smaller plots (experimental fields) and when human resources are limited.

Most studies (98\%) reported sampling depth (Table 4), which was $15 \mathrm{~cm}$ or less in $18 \%$ of them. The ideal sample depth should be chosen based on: the characteristics of the earthworm community, such as the presence or not of larger species that build deep galleries; soil structure, including the depth of specific layers; anthropogenic influence, like ploughing depth; and sampling season or climatic conditions at and/or just before the sampling date. During the rainy season, mostearthworms tend to be concentrated in the $0-10-\mathrm{cm}$ layer (Lavelle \& Kohlmann, 1984), but, in the dry season, they often migrate to greater depths and/or coil up into a ball, staying in a state of quiescence or even diapause (Abe \& Buck, 1985; Drumond et al., 2013), when they are often more difficult to collect and/ or in a lower abundance. However, even in the rainy season, particularly when it coincides with warmer temperatures, earthworms often move below $10-\mathrm{cm}$ depth, especially at the hottest time of the day, in order to escape excessive heat and the lower soil moisture in the upper layer (Lavelle, 1983, 1988b). Therefore, it is important to choose the adequate monolith size and sample depth, based on previous observations in-situ, which will reveal the possible occurrence of larger earthworm species and the depth of their activity, as well as where larger holes should be dug (Caballero, 1976; Römbke et al., 2005; Cardoso et al., 2014).

Earthworm biomass is rarely reported in soil fauna studies in Brazil (Brown \& James, 2007). It was only measured in $31 \%$ of the publications (314 sites), likely due to the additional effort - especially time - needed for this task (Bignell et al., 2008). Still, biomass measurements must be standardized for use in ecological investigations and comparisons between studies. Active earthworms normally have a variable proportion of soil in their intestine, generally $10-20 \%$ fresh weight, which can affect the precision of the fresh earthworm biomass measurements (University of Minnesota, 2020). For this reason, some researchers allow earthworms to void their guts before sacrificing and weighing them (Lee, 1985); however, this procedure is not feasible when collecting earthworms in the field, where they are often amputated and/or injured, which can affect the survival of the collected individuals. The best way to measure biomass in order to allow comparisons between studies is to determine

Table 4. Variables associated with earthworm sampling identified in the literature review, number of studies (percentage of total in parentheses) with this information available, and number of samples included in the database (№ $\mathrm{db})^{(1)}$.

\begin{tabular}{|c|c|c|c|}
\hline Variable & Description & № of studies (\%) & № $\mathrm{db}$ \\
\hline Size of dug holes & Dimensions of hole side $\mathrm{x}$ side or diameter if cylindrical $(\mathrm{cm})$ & $122(98)$ & 758 \\
\hline Number of holes & Number of samples per site & $118(95)$ & 748 \\
\hline Depth & Sample depth $(\mathrm{cm})$, with a minimum of $10 \mathrm{~cm}$ & $121(98)$ & 755 \\
\hline Density & Mean number of earthworm individuals $\left(\mathrm{m}^{-2}\right)$ found at the site & $124(100)$ & 765 \\
\hline Biomass & $\begin{array}{l}\text { Mean earthworm biomass }\left(\mathrm{g} \mathrm{m}^{-2}\right) \text { at the site (fresh weight in preservative } \\
\text { liquid, including intestinal contents) }\end{array}$ & $38(31)$ & 314 \\
\hline Species identification & Species identified (yes or no) & $30(24)$ & 266 \\
\hline
\end{tabular}

${ }^{(1)}$ Database available at Nadolny et al. (2020). 
ash-free dry weights with a freeze-drier (Brown et al., 1998). However, once this procedure is done, it is no longer possible to identify individuals, but it is possible to make some projections of gut weight for a subsample of the species, making a correction for the others (Martin, 1986). Therefore, a practical way to present biomass data is to specify how weighing was done; normally fresh weight, including intestinal content, is determined in alcohol at concentrations of $70 \%$ or greater or in formaldehyde from 4 to $10 \%$ (Baker \& Lee, 1993). If there is time or it is possible, an adjustment can be made to obtain the corrected biomass (without gut contents) using data from the species. Material preserved in formaldehyde is easier to weigh and less dehydrated than that in ethanol, since the water content of the formaldehyde solution is higher (generally $>90 \%$ ) than that of ethanol (generally < 30\%) (Baker \& Lee, 1993; ISO, 2018). However, for molecular studies using DNA, ethanol (> $90 \%$ ) is recommended.

The ISO (2015) proposal is regularly used in ecotoxicological standard field tests. According to Dunger \& Fiedler (1997), earthworms seem to lose about 10 to $20 \%$ of their mass during fixation, but, since this is about the same as the mass of the gut content, compensation is not necessary. The measured fresh mass can be converted to dry mass by multiplying its value by a factor of 0.15 (Petersen \& Luxton, 1982), which was determined using mineral soil dwellers (endogeic species) from European grassland sites; therefore, this factor may vary considerably depending on the ecological category, i.e., it is smaller in epigeic species than in endogeic ones. Hence, adaptations may be needed in local studies, as well as further work to obtain more precise estimates for the species in-situ.

After sampling, species are normally identified in the laboratory, since most of the common tropical and subtropical earthworms require dissection for an adequate identification (Righi, 1997). For this reason, in Brazil, earthworm identification is not an easy task, having been performed in only $24 \%$ of the studies (Table 4). The proper identification of species improves the assessments of their interactions with the soil environment, and the estimation of their potential effects on soil properties and processes, which are closely linked to their ecological category/functional group (Brown et al., 2000). Therefore, in as far as is possible, the collected species should be identified, in order to evaluate the impacts of land use on biodiversity and to estimate possible impacts of species on soil and associated ecosystem services (Podgaiski et al., 2011).

\section{Recommendations for standardization}

Studies relating earthworms to environmental and soil factors must consider the multifactorial nature of soil-animal-plant relationships, and evaluate a minimum set of variables that are important determinants of earthworm populations in terrestrial ecosystems. A list of these variables and a brief explanation of the reasons for their recommendation is given in Table 5, aiming to increase the number of publications that simultaneously provide data on a wide range of soil and environmental variables. A good, detailed description of the sampling site, climate, and vegetation and soil type, including previous and current land uses and soil management, could improve the understanding of the relationships between environmental factors and earthworm abundance and diversity at a particular site.

Soil variables, evaluated in less than $50 \%$ of the studies, are not so difficult or costly to determine, and can be easily incorporated into the project budget of studies involving earthworm and/or soil fauna sampling. Furthermore, it is not difficult to obtain a soil sample for routine soil analysis, which would be enough to adequately describe the soil chemical and physical environment of a site as an earthworm habitat. Considering the data evaluated in this review, it is recommended that future studies evaluating earthworm populations measure, from at least a composite soil sample: $\mathrm{pH}$; moisture; $\mathrm{Ca}, \mathrm{Mg}, \mathrm{K}, \mathrm{P}, \mathrm{C}$, and $\mathrm{N}$ contents by combustion; $\mathrm{CEC}$; and soil texture, including percentage of sand, silt, and clay. However, if time and resources are not an issue, then samples could be taken from around or within each earthworm monolith (Swift \& Bignell, 2001). Furthermore, those variables should be measured using standard methods, in order to enhance comparisons between studies. Slightly similar lists were proposed by ISO (2018) and Swift \& Bignell (2001) for soil biodiversity studies worldwide.

The data on earthworm abundance and biomass measured at each site and/or individual treatment type should be either presented in a table in the publication, or as an appendix or supplementary table 
to the paper. The data shown in the figures as means per set of treatments or as a part of larger "groups" of soil animals (e.g., detritivores or engineers) should be individualized for earthworms (and other macrofauna groups) per treatment and provided in supplementary tables, so that they can be used in future comparative studies (Nadolny, 2017). A preliminary, rapid sampling at a site is essential before undertaking intensive sampling, to reveal the size of the earthworms present and the depth of their activities and also to determine the intensity and appropriate soil volume for sampling. Although earthworm species-level data provide essential information on niches and the relationships of species presence and abundance with soil, vegetation

Table 5. List of standard environmental, soil, and earthworm attributes to be provided/measured in studies on earthworm populations.

\begin{tabular}{|c|c|c|}
\hline Attribute & Standard list of variables & Reason for data inclusion \\
\hline \multirow{9}{*}{ Environmental } & $\begin{array}{l}\text { Sampling date/season and } \\
\text { Köppen's climate }\end{array}$ & $\begin{array}{l}\text { Allows estimation of related weather conditions, particularly temperature, } \\
\text { rainfall, and soil moisture }\end{array}$ \\
\hline & Location/geographical coordinates & $\begin{array}{l}\text { Allows mapping of sampling sites and relation to other environmental variables } \\
\text { such as soil type and vegetation }\end{array}$ \\
\hline & Annual mean precipitation & Affects mainly soil moisture contents \\
\hline & $\begin{array}{l}\text { Soil cover/vegetation type and type of } \\
\text { native vegetation }\end{array}$ & $\begin{array}{l}\text { Affects soil cover (protection) and the inputs of organic resources (food quantity } \\
\text { and quality) }\end{array}$ \\
\hline & Crop type & $\begin{array}{l}\text { Affects soil cover, soil and crop management, and the inputs of organic } \\
\text { resources (food quantity and quality) }\end{array}$ \\
\hline & Soil management & $\begin{array}{l}\text { Soil preparation (various forms of tillage) impacts soil structure; for example, } \\
\text { a higher intensity is prejudicial to earthworms, whereas no-tillage tends to be } \\
\text { beneficial }\end{array}$ \\
\hline & Past and current land use & $\begin{array}{l}\text { Time in current land use is a measure of the intensity of positive or negative } \\
\text { potential impacts on earthworms; previous land use determines possible legacy } \\
\text { effects on earthworm populations }\end{array}$ \\
\hline & Pesticide use/type & $\begin{array}{l}\text { Various pesticide formulations and active ingredients may have negative im- } \\
\text { pacts on earthworms }\end{array}$ \\
\hline & Fertilizer use/type & $\begin{array}{l}\text { Fertilization increases primary production and the inputs of organic materials } \\
\text { and mineral resources to the soil; long-term intensive fertilization with } \\
\text { inorganic } \mathrm{N} \text { acidifies soil, impacting earthworm populations }\end{array}$ \\
\hline \multirow{6}{*}{ Soil } & Soil type & $\begin{array}{l}\text { Affects soil depth and the mineral and organic resources available for the } \\
\text { earthworms }\end{array}$ \\
\hline & $\mathrm{pH}$ & $\begin{array}{l}\text { Earthworm species have variable tolerance to } \mathrm{pH} \text {, which is also related to the } \\
\text { available mineral and organic resources }\end{array}$ \\
\hline & Soil moisture, $\mathrm{K}, \mathrm{Ca}, \mathrm{Mg}$, and $\mathrm{P}$ & Important for earthworm metabolism \\
\hline & $\mathrm{C}$ and $\mathrm{N}$ & $\begin{array}{l}\text { Related to food resource availability (quantity and quality), important for } \\
\text { earthworm metabolism }\end{array}$ \\
\hline & Cation exchange capacity & Related to plant productivity potential and ability to provide food resources \\
\hline & Sand, clay, silt, and textural class & $\begin{array}{l}\text { Affects the physical environment of the earthworm; related to food resource } \\
\text { availability and soil hydrology }\end{array}$ \\
\hline \multirow{6}{*}{ Earthworm sampling } & Size of holes & $\begin{array}{l}\text { Affects sampling efficiency; larger holes are needed when large earthworm } \\
\text { species are present }\end{array}$ \\
\hline & Number of holes & $\begin{array}{l}\text { Related to sampling effort; a minimum number is needed to adequately sample } \\
\text { earthworm communities }\end{array}$ \\
\hline & Depth of holes & $\begin{array}{l}\text { Affects sampling efficiency; deeper holes are needed in the dry season and when } \\
\text { deep-burrowing earthworms are present }\end{array}$ \\
\hline & Density & Main parameter related to earthworm presence in soils \\
\hline & Biomass & $\begin{array}{l}\text { Important to determine potential impacts of earthworms on soil physical } \\
\text { properties }\end{array}$ \\
\hline & Species identification & $\begin{array}{l}\text { Allows determining biodiversity and facilitates the estimation of potential } \\
\text { impacts on soil functioning }\end{array}$ \\
\hline
\end{tabular}


and management variables, total earthworm biomass and density are easier to determine and were considered by Doube \& Schmidt (1997) as more stable (less variable) than data on species in studies using earthworms as environmental bioindicators. However, given the large number of native and endemic species present in Brazilian soils (Brown et al., 2013), it is important to obtain data on these species and any preferences they might have for particular soil and environmental conditions, in order to enhance conservation and management efforts. The identification of earthworm species requires expertise, and, in many cases, proper identification is only possible by a taxonomist, although there are a few specialists in Brazil and elsewhere who can also identify Brazilian earthworm species. When the identification of the material is not possible, care should be taken to preserve the collected species correctly, and contact should be made with an appropriate specialist or institution that can receive and store the material (e.g., a museum collection) to be identified later (if possible), reducing the risk of loss or damage by improper conservation.

The above suggestions for data collection are valid not only for earthworm sampling, but also for overall soil macrofauna population studies. This should facilitate the standardization of the information provided in publications and comparisons between/ among them. Considering the growing scientific body in soil zoology and overall interest in the potential use of earthworms and other soil animals as soil and environmental quality indicators (Bünemann et al., 2018), the use of standard methods of analysis and data collection are essential to optimize research efforts, allow a wider use of the data and derived publications, and increase the life-span and usefulness of studies on earthworm populations in Brazilian ecosystems and worldwide.

\section{References}

ABE, A.S.; BUCK, N. Oxygen uptake of active and aestivating earthworm Glossoscolex paulistus (Oligochaeta, Glossoscolecidae). Comparative Biochemistry and Physiology, v.81, p.63-66, 1985. DOI: https://doi.org/10.1016/03009629(85)90267-1.

ALBERTON, J.V.; OLIVEIRA FILHO, L.C.I. de; VIAPIANA, C.M.; BIANCO, V.D.; MIQUELLUTI, D.J.; SANTOS, J.C.P. Macrofauna do solo em áreas reconstruídas após mineração de carvão. In: REUNIÃO BRASILEIRA DE FERTILIDADE DO SOLO E NUTRIÇÃO DE PLANTAS, 29.; REUNIÃO
BRASILEIRA SOBRE MICORRIZAS, 13.; SIMPÓSIO BRASILEIRO DE MICROBIOLOGIA DO SOLO, 11.; REUNIÃO BRASILEIRA DE BIOLOGIA DO SOLO, 8., 2010, Guarapari. Fontes de nutrientes e produção agrícola: modelando o futuro: anais. Viçosa: SBCS, 2010. FERTBIO 2010.

ALMEIDA, M.V.R. de; OLIVEIRA, T.S. de; BEZERRA, A.M.E. Biodiversidade em sistemas agroecológicos no município de Choró, CE, Brasil. Ciência Rural, v.39, p.1080-1087, 2009. DOI: https://doi.org/10.1590/S0103-84782009005000047.

ALVARES, C.A.; STAPE, J.L.; SENTELHAS, P.C.; GONÇALVES, J.L. de M.; SPAROVEK, G. Köppen's climate classification map for Brazil. Meteorologische Zeitschrift, v.22, p.711-728, 2013. DOI: https://doi.org/10.1127/09412948/2013/0507.

ALVES, M.V. Fauna do solo influenciada pelo uso de fertilizantes minerais e dejetos suínos na sucessão aveia milho, sob semeadura direta. 2007. 46p. Dissertação (Mestrado) Universidade do Estado de Santa Catarina, Lages.

ALVES, M.V. Propriedades físicas do solo e oligochaetas em diferentes sistemas de uso da terra no alto Solimões - AM. 2010. 118p. Tese (Doutorado) - Universidade Federal de Lavras, Lavras.

ANDERSON, J.M.; INGRAM, J.S.I. (Ed.). Tropical soil biology and fertility: a handbook of methods. $2^{\text {nd }}$ ed. Wallingford: CAB International, 1993. 221p.

ANDRÉA, M.M. de. O uso de minhocas como bioindicadores de contaminação de solos. Acta Zoológica Mexicana, v.26, p.95107, 2010. Número especial 2. DOI: https://doi.org/10.21829/ azm.2010.262880.

AQUINO, A.M. de; DIONÍSIO, J.A.; ROSSETTI, R.R.; CORREIA, M.E.F.; NUNES, D.H.; PASINI, A. Minhocas: aspectos gerais e ecológicos em sistemas agrícolas. Seropédica: Embrapa Agrobiologia, 2005. p.7-23. (Embrapa Agrobiologia. Documentos, 207).

AQUINO, A.M. de; RICCI, M. dos S.; PINHEIRO, A. dos S. Avaliação da macrofauna do solo em café orgânico e convencional utilizando um método modificado do TSBF. In: REUNIÃO BRASILEIRA DE FERTILIDADE DO SOLO E NUTRIÇÃO DE PLANTAS, 24; REUNIÃO BRASILEIRA SOBRE MICORRIZAS, 8.; SIMPÓSIO BRASILEIRO DE MICROBIOLOGIA DO SOLO, 6.; REUNIÃO BRASILEIRA DE BIOLOGIA DO SOLO, 3., 2000, Santa Maria. Biodinâmica do solo: [anais]. [Viçosa]: Sociedade Brasileira de Ciência do Solo; [São Paulo]: Sociedade Brasileira de Microbiologia; Santa Maria: Universidade Federal de Santa Maria, 2000. FERTBIO 2000.

ARAÚJO, A.O. Avaliação de propriedades físicas dos solos e da macrofauna edáfica em áreas submetidas a manejo florestal de vegetação nativa na Chapada do Araripe. 2010. 76p. Dissertação (Mestrado) - Universidade Federal do Ceará, Fortaleza.

ARAÚJO, V.F.P.; BANDEIRA, A.G.; VASCONCELLOS, A. Abundance and stratification of soil macroarthropods in a Caatinga forest in Northeast Brazil. Brazilian Journal of Biology, v.70, p.737-746, 2010. Suppl. DOI: https://doi.org/10.1590/S151969842010000400006 . 
ARAUUJO, Y.M.; LUIZÃO, F.J. Populações de minhocas em experimento de manipulação de liteira em solos de capoeira na Amazônia Central. In: CONGRESSO BRASILEIRO DE CIÊNCIA DO SOLO, 33., 2011, Uberlândia. Solos nos biomas brasileiros: sustentabilidade e mudanças climáticas: anais. Uberlândia: SBCS: UFU: ICIAG, 2011.

AYRES, I.; GUERRA, R.A.T. Água como fator limitante na distribuição das minhocas (Annelida, Oligochaeta) da Amazônia Central. Acta Amazonica, v.11, p.77-86, 1981. DOI: https://doi.org/10.1590/1809-43921981111077.

AZEVEDO, P.T.M.; BROWN, G.G.; BARETTA, D.; PASINI, A.; NUNES, D.H. Populações de minhocas amostradas por diferentes métodos de coleta (elétrico, químico e manual) em ecossistemas da região de Londrina, Paraná, Brasil. Acta Zoológica Mexicana, v.26, p.79-93, 2010. Número especial 2. DOI: https://doi.org/10.21829/azm.2010.262879.

BAKER, G.H.; LEE, K.E. Earthworms. In: CARTER, M.R. (Ed.). Soil sampling and methods of analysis. Boca Raton: Lewis Publishers, 1993. p.359-371.

BANDEIRA, A.G.; HARADA, A.Y. Densidade e distribuição vertical de macroinvertebrados em solos argilosos e arenosos na Amazônia central. Acta Amazonica, v.28, p.191-204, 1998. DOI: https://doi.org/10.1590/1809-43921998282204.

BARETTA, D. Fauna edáfica como bioindicadora da qualidade do solo em áreas com Araucaria angustifolia no Estado de São Paulo. 2007. 156p. Tese (Doutorado) - Universidade de São Paulo, Piracicaba.

BARETTA, D.; BROWN, G.G.; JAMES, S.W.; CARDOSO, E.J.B.N. Earthworm populations sampled using collection methods in Atlantic forests with Araucaria angustifolia. Scientia Agricola, v.64, p.384-392, 2007. DOI: https://doi.org/10.1590/ S0103-90162007000400009.

BARETTA, D.; SANTOS, J.C.P.; MAFRA, Á.L.; WILDNER, L. do P.; MIQUELLUTI, D.J. Fauna edáfica avaliada por armadilhas e catação manual afetada pelo manejo do solo na região Oeste Catarinense. Revista de Ciências Agroveterinárias, v.2, p.97106, 2003.

BARETTA, D.; TESTA, M.; ROCHA, E.; LUCIANER, E.; BARTZ, M.L.C.; BROWN, G.G.; SIMIONI, F.J.; PAIANO, D.; SPAGNOLLO, E.; WILDNER, L. do P.; VEIGA, M. da. As minhocas e suas relações com atributos físico-químicos no Oeste e Meio-Oeste do Estado de Santa Catarina. In: SEMINÁRIO DE ENSINO, PESQUISA E EXTENÇÃO - CEO/UDESC, 3., 2013, Chapecó. [Anais]. Chapecó: UDESC, 2013. $3^{\circ}$ SEPE.

BARRIGOSSI, J.A.F.; BROWN, G.G.; PEDRETTI JÚNIOR, C. Minhocas em arroz irrigado: pragas ou benéficas? In: CONGRESSO BRASILEIRO DE ARROZ IRRIGADO, 6., 2009, Porto Alegre. Estresses e sustentabilidade: desafios para a lavoura arrozeira: [anais]. Porto Alegre: Sosbai, 2009.

BARRION, A.T.; LITSINGER, J.A. Dichogaster nr. curgensis Michaelsen (Annelida: Octochaetidae): an earthworm pest of terraced rice in the Philippine Cordilleras. Crop Protection, v.16, p.89-93, 1997. DOI: https://doi.org/10.1016/S0261-2194(96)000580 .

Pesq. agropec. bras., Brasília, v.55, e01006, 2020

DOI: 10.1590/S1678-3921.pab2020.v55.01006
BARROS, E.; NEVES, A.; BLANCHART, E.; FERNANDES, E.C.M.; WANDELLI, E.; LAVELLE, P. Development of the soil macrofauna community under silvopastoral and agrosilvicultural systems in Amazonia. Pedobiologia, v.47, p.273-280, 2003. DOI: https://oi.org/10.1078/0031-4056-00190.

BARROS, E.; PASHANASI, B.; CONSTANTINO, R.; LAVELLE, P. Effects of land-use system on the soil macrofauna in western Brazilian Amazonia. Biology and Fertility of Soils, v.35, p.338347, 2002. DOI: https://doi.org/10.1007/s00374-002-0479-z.

BARROS, M.E.; BLANCHART, E.; NEVES, A.; DESJARDINS, T.; CHAUVEL, A.; SARRAZIN, M.; LAVELLE, P. Relação entre a macrofauna e a agregação do solo em três sistemas na Amazônia Central. In: CONGRESSO LATINO AMERICANO DE CIÊNCIA DO SOLO, 13.; REUNIÃO BRASILEIRA DE BIOLOGIA DO SOLO, 1.; SIMPÓSIO BRASILEIRO SOBRE MICROBIOLOGIA DO SOLO, 4.; REUNIÃO BRASILEIRA SOBRE MICORRIZAS, 6.; REUNIÃO BRASILEIRA DE MANEJO E CONSERVAÇÃO DO SOLO E DA ÁGUA, 11., 1996, Águas de Lindóia. Solo suelo 96. Piracicaba: ESALQ: SLCS: SBCS: CEA: SBM, 1996.

BARTZ, M.L.C.; BROWN, G.G.; PASINI, A.; FERNANDES, J. de O.; CURMI, P.; DORIOZ, J.; RALISCH, R. Earthworm communities in organic and conventional coffee cultivation. Pesquisa Agropecuária Brasileira, v.44, p.928-933, 2009a. DOI: https://doi.org/10.1590/S0100-204X2009000800019.

BARTZ, M.L.C.; BROWN, G.G.; PASINI, A.; MELLO, I.; BORTOLUZZI, J.; TAMIOZZO, T.; PILECCO, O.P.; LUTZ, R.A. de T. Minhocas como bioindicadores de qualidade do sistema plantio direto na palha. In: ENCONTRO LATINO-AMERICANO DE ECOLOGIA E TAXONOMIA DE OLIGOQUETAS, 4., 2010, Curitiba. Minhocas como bioindicadoras ambientais: princípios e práticas: anais. Colombo: Embrapa Florestas, 2010. (Embrapa Florestas. Documentos, 199). Editores: George Gardner Brown, Cíntia Carla Niva, Klaus Dieter Sautter, Amarildo Pasini, Mac A. Callaham Jr. e Renato Marques. ELAETAO 4.

BARTZ, M.L.C.; BROWN, G.G.; PASINP, A.; LIMA, A.C.R. de; GASSEN, D.N. As minhocas e o manejo do solo: o caso do plantio direto do arroz irrigado. Revista Plantio Direto, v.19, p.4$8,2009 b$.

BARTZ, M.L.C.; JAMES, S.W.; PASINI, A.; BROWN, G.G. New earthworm species of Glossoscolex Leuckart, 1835 and Fimoscolex Michaelsen, 1900 (Clitellata: Glossoscolecidae) from Northern Paraná, Brazil. Zootaxa, v.3458, p.59-85, 2012. DOI: https://doi.org/10.11646/zootaxa.3458.1.3.

BARTZ, M.L.C.; PASINI, A.; BROWN, G.G. Earthworm richness, abundance and biomass in different land use systems in northern Paraná, Brazil (Oligochaeta). In: PAVLÍČEK, T.; CARDET, P.; ALMEIDA, M.T.; PASCOAL, C.; CÁSSIO, F. (Ed.). Advances in Earthworm Taxonomy VI (Annelida: Oligochaeta). Heidelberg: Kasparek Verlag, 2014. p.59-73. Proceedings of the $6^{\text {th }}$ International Oligochaeta Taxonomy Meeting ( $6^{\text {th }}$ IOTM), Palmeira de Faro, April 22-25, 2013.

BARTZ, M.L.C.; PASINI, A.; BROWN, G.G. Earthworms as soil quality indicators in Brazilian no-tillage systems. Applied Soil Ecology, v.69, p.39-48, 2013. DOI: https://doi.org/10.1016/j. apsoil.2013.01.011. 
BATISTA, I. Atributos edáficos e fauna do solo em áreas de integração lavoura-pecuária no Bioma Cerrado, Mato Grosso do Sul. 2011. 86p. Dissertação (Mestrado) - Universidade Federal Rural do Rio de Janeiro, Seropédica.

BATISTA, I.; CORREIA, M.E.F.; PEREIRA, M.G.; BIELUCZYK, W.; SCHIAVO, J.A.; ROUWS, J.R.C. Frações oxidáveis do carbono orgânico total e macrofauna edáfica em sistema de integração lavoura-pecuária. Revista Brasileira de Ciência do Solo, v.38, p.797-809, 2014. DOI: https://doi.org/10.1590/S010006832014000300011.

BENAZZI, E. dos S. Produtividade, fertilidade e fauna do solo em um Argissolo Amarelo cultivado com cana-de-açúcar sob diferentes sistemas de colheita. 2011. 112p. Dissertação (Mestrado) - Universidade Federal Rural do Rio de Janeiro, Seropédica.

BENITO, N.P. Diversidade da macrofauna invertebrada do solo em áreas agrícolas de Jaguapitã - PR. 2005. 91p. Tese (Doutorado) - Universidade Estadual de Londrina, Londrina.

BENITO, N.P. Interferência de sistemas de cultivo sobre a macrofauna invertebrada do solo. 2002. 60p. Dissertação (Mestrado) - Universidade Estadual de Londrina, Londrina.

BENITO, N.P.; BOBILlIER, B.; BROSSARD, M.; PASINI, A. Impacto do desmatamento e da renovação de pastagem sobre a macrofauna edáfica do solo no Cerrado. In: INTERNATIONAL SYMPOSIUM SOIL FUNCTIONING UNDER PASTURES IN INTERTROPICAL AREAS, 2000, Brasília. [Anais]. Planaltina: Embrapa Cerrados, 2000. 1 CD-ROM. Edited and organized by the Soil Pasture Project.

BENITO, N.P.; BROSSARD, M.; PASINI, A.; GUIMARÃES, M. de F.; BOBILLIER, B. Transformations of soil macroinvertebrate populations after native vegetation conversion to pasture cultivation (Brazilian Cerrado). European Journal of Soil Biology, v.40, p.147-154, 2004. DOI: https://doi.org/10.1016/j. ejsobi.2005.02.002.

BENITO, N.P.; GUIMARÃES, M. de F.; PASINI, A. Caracterização de sistemas de manejo em latossolo vermelho utilizando parâmetros biológicos, físicos e químicos. Semina: Ciências Agrárias, v.29, p.473-484, 2008. DOI: https://doi.org/10.5433/1679-0359.2008v29n3p473.

BENTO, M.A.B. Avaliação da qualidade dos substratos minerados em cinco cascalheiras revegetadas no Distrito Federal. 2009. 128p. Dissertação (Mestrado) - Universidade de Brasília, Brasília.

BERNHARD-REVERSAT, F.; LOUMETO, J.J.; LACLAU, J.P. Litterfall, litter quality and decomposition changes with eucalypt hybrids and plantation age. In: BERNHARD-REVERSAT, F. (Ed.). Effect of exotic tree plantations on plant diversity and biological soil fertility in the Congo savanna: with special reference to eucalypts. Bogor: CIFOR, 2001. p.23-30.

BIANCHI, M. de O. Avaliação da funcionalidade do solo em sistemas florestais enriquecidos com leguminosas. 2009. 56p. Dissertação (Mestrado) - Universidade Federal Rural do Rio de Janeiro, Seropédica.

BIANCHI, M.O.; AQUINO, A.M.; ALMEIDA, E. Distribuição vertical da macrofauna do solo em várias safras do milho agroecológico em área do produtor familiar. In: CONGRESSO BRASILEIRO DE CIÊNCIA DO SOLO, 31., 2007, Gramado. Conquistas e desafios da Ciência do Solo brasileira: anais. [Porto Alegre]: SBCS, Núcleo Regional Sul, 2007.

BIGNELL, D.; CONSTANTINO, R.; CSUZDI, C.; KARYANTO, A.; KONATÉ, S.; LOUZADA, J.; SUSILO, F.-X.; TONDOH, J.E.; ZANETTI, R. Macrofauna. In: MOREIRA, F.M.S.; HUISING, E.J.; BIGNELL, D.E. (Ed.). A handbook of tropical soil biology: sampling and characterization of below-ground biodiversity. London: Earthscan, 2008. p.43-83.

BLANCHART, E.; BERNOUX, M.; SARDA, X.; SIQUEIRA NETO, M.; CERRI, C.C.; PICCOLO, M.; DOUZET, J.-M.; SCOPEL, E.; FELLER, C. Effect of direct seeding mulch-based systems on soil carbon storage and macrofauna in central Brazil. Agriculturae Conspectus Scientificus, v.72, p.81-87, 2007.

BLUME, H.-P.; BRÜMMER, G.W.; FLEIGE, H.; HORN, R.; KANDELER, E.; KÖGEL-KNABNER, I.; KRETZSCHMAR, R.; STAHR, K.; WILKE, B.-M. Soil Science. Heidelberg: Springer, 2016. 618p. DOI: https://doi.org/10.1007/978-3-642-30942-7.

BRAGA, D.P.P. Sistemas agroflorestais com cacau para recuperação de áreas degradadas, em São Félix do Xingu PA. 2015. 210p. Dissertação (Mestrado) - Universidade de São Paulo, Piracicaba.

BRIGANTE, J. Comparação de algumas comunidades de macrofauna e microrganismos de solo, encontradas em áreas de mata e pastagens, em um Latossolo. 2000. 105p. Tese (Doutorado) - Universidade Federal de São Carlos, São Carlos.

BRIONES, M.J.I.; OSTLE, N.J.; PIEARCE, T.G. Stable isotopes reveal that the calciferous gland of earthworms is a $\mathrm{CO}_{2}$-fixing organ. Soil Biology and Biochemistry, v.40, p.554-557, 2008. DOI: https://doi.org/10.1016/j.soilbio.2007.09.012.

BRIONES, M.J.I.; SCHMIDT, O. Conventional tillage decreases the abundance and biomass of earthworms and alters their community structure in a global meta-analysis. Global Change Biology, v.23, p.4396-4419, 2017. DOI: https://doi.org/10.1111/ gcb.13744.

BRITO, M.F. de; TSUJIGUSHI, B.P.; OTSUBO, A.A.; SILVA, R.F. da; MERCANTE, F.M. Diversidade da fauna edáfica e epigeica de invertebrados em consórcio de mandioca com adubos verdes. Pesquisa Agropecuária Brasileira, v.51, p.253-260, 2016. DOI: https://doi.org/10.1590/S0100-204X2016000300007.

BROSSARD, M.; FREGONEZI, G.A. de F.; GUIMARÃES, M. de F.; CONTI MEDINA, C. de; PASINI, A.; VILELA, L.; AYARZA, M.A. Analysis of an illustrative interaction between structural features and earthworm populations in Brazilian ferralsols. Comptes Rendus Geoscience, v.344, p.41-49, 2012. DOI: https://doi.org/10.1016/j.crte.2011.12.001.

BROWN, G.G.; BAROIS, I.; LAVELLE, P. Regulation of soil organic matter dynamics and microbial activity in the drilosphere and the role of interactions with other edaphic functional domains. European Journal of Soil Biology, v.36, p.177-198, 2000. DOI: https://doi.org/10.1016/S1164-5563(00)01062-1.

BROWN, G.G.; BENITO, N.P.; PASINI, A.; SAUTTER, K.D.; GUIMARÃES, M. de F.; TORRES, E. No-tillage greatly increases earthworm populations in Paraná state, Brazil. Pedobiologia, 
v.47, p.764-771, 2003. DOI: https://doi.org/10.1078/0031-405600256 .

BROWN, G.G.; CALLAHAM, M.A.; NIVA, C.C.; FEIJOO, A.; SAUTTER, K.D.; JAMES, S.W.; FRAGOSO, C.; PASINI, A.; SCHMELZ, R.M. Terrestrial oligochaete research in Latin America: the importance of the Latin American meetings on oligochaete ecology and taxonomy. Applied Soil Ecology, v.69, p.2-12, 2013. DOI: https://doi.org/10.1016/j.apsoil.2012.12.006.

BROWN, G.G.; DOMÍNGUEZ, J. Uso das minhocas como bioindicadoras ambientais: princípios e práticas - o $3^{\circ}$ Encontro Latino Americano de Ecologia e Taxonomia de Oligochaetas. Acta Zoológica Mexicana, v.26, p.1-18, 2010. Número especial 2. DOI: https://doi.org/10.21829/azm.2010.262874.

BROWN, G.G.; HENDRIX, P.F.; BEARE, M.H. Earthworms (Lumbricus rubellus) and the fate of ${ }^{15} \mathrm{~N}$ in surface-applied sorghum residues. Soil Biology and Biochemistry, v.30, p.17011705, 1998. DOI: https://doi.org/10.1016/S0038-0717(97)00277-0.

BROWN, G.G.; JAMES, S.W. Ecologia, biodiversidade e biogeografia das minhocas no Brasil. In: BROWN, G.G.; FRAGOSO, C. (Ed.). Minhocas na América Latina: biodiversidade e ecologia. Londrina: Embrapa Soja, 2007. p.297381.

BROWN, G.G.; JAMES, S.W.; PASINI, A.; NUNES, D.H.; BENITO, N.P.; MARTINS, P.T.; SAUTTER, K.D. Exotic, peregrine, and invasive earthworms in Brazil: diversity, distribution, and effects on soils and plants. Caribbean Journal of Science, v.42, p.339-358, 2006a.

BROWN, G.G.; JAMES, S.W.; SAUTTER, K.D.; PASINI, A.; BENITO, N.P.; NUNES, D.H.; KORASAKI, V.; SANTOS, É.F. dos; MATSUMURA, C.; MARTINS, P.T.; PAVÃO, A.; SILVA, S.H. da; GARBELINI, G.; TORRES, E. Avaliação das populações de minhocas como bioindicadores ambientais no Norte e Leste do Estado do Paraná. In: SARAIVA, O.F. (Ed.). Resultados de pesquisa da Embrapa Soja 2003: manejo de solos, plantas daninhas e agricultura de precisão. Londrina: Embrapa Soja, 2004. p.30-46. (Embrapa Soja. Documentos, 253).

BROWN, G.G.; JAMES, S.W.; SAUTTER, K.D.; PASINI, A.; BENITO, N.P.; NUNES, D.H.; KORASAKI, V.; SANTOS, É.F. dos; MATSUMURA, C.; MARTINS, P.T.; PAVÃO, A.; SILVA, S.H. da; GARBELINI, L.G.; TORRES, E. Avaliação das populações de minhocas como bioindicadores ambientais no Norte e no Leste do Estado do Paraná. In: SARAIVA, O.F.; LEITE, R.M.V.B. de C. (Ed.). Resultados de pesquisa da Embrapa Soja 2005. Londrina: Embrapa Soja, 2008. p.20-29. (Embrapa Soja. Documentos, 296).

BROWN, G.G.; MASCHIO, W.; FROUFE, L.C.M. Macrofauna do solo em sistemas agroflorestais e Mata Atlântica em regeneração nos municípios de Barra do Turvo, SP, e Adrianópolis, PR. Colombo: Embrapa Florestas, 2009. (Embrapa Florestas. Documentos, 184).

BROWN, G.G.; NIVA, C.C.; ZAGATTO, M.R.G.; FERREIRA, S. de A.; NADOLNY, H.S.; CARDOSO, G.B.X.; SANTOS, A.; MARTINEZ, G. de A.; PASINI, A.; BARTZ, M.L.C.; SAUTTER, K.D.; THOMAZINI, M.J.; BARETTA, D.; SILVA, E. da; ANTONIOLLI, Z.I.; DECAËNS, T.; LAVELLE, P.M.;
SOUSA, J.P.; CARVALHO, F. Biodiversidade da fauna do solo e sua contribuição para os serviços ambientais. In: PARRON, L.M.; GARCIA, J.R.; OLIVEIRA, E.B. de; BROWN, G.G.; PRADO, R.B. (Ed.). Serviços ambientais em sistemas agrícolas e florestais do Bioma Mata Atlântica. Brasília: Embrapa, 2015. p.122-154.

BROWN, G.G.; PASINI, A.; BENITO, N.P.; AQUINO, A.M. de; CORREIA, M.E.F. Diversity and functional role of soil macrofauna comunities in Brazilian no-tillage agroecosystems: a preliminary analysis. In: INTERNATIONAL SYMPOSIUM ON MANAGING BIODIVERSITY IN AGRICULTURAL ECOSYSTEMS, 2001, Montreal. [Proceedings]. Montreal: UNU, 2001. Available at: $<$ http://unu.edu/env/plec/cbd/abstracts/Brown. doc>. Accessed on: Nov. 32015.

BROWN, G.G.; RÖMBKE, J.; HÖFER, H.; VERHAAGH, M.; SAUTTER, K.D.; SANTANA, D.L. de Q. Biodiversity and function of soil animals in Brazilian agroforestry systems. In: GAMA-RODRIGUES, A.C. da; BARROS, N.F. de; GAMARODRIGUES, E.F. da; FREITAS, M.S.M.; VIANA, A.P.; JASMIN, J.M.; MARCIANO, C.R.; CARNEIRO, J.G. de A. (Ed.). Sistemas agroflorestais: bases científicas para o desenvolvimento sustentável. Campos dos Goytacazes: Universidade Estadual do Norte Fluminense: Sociedade Brasileira de Sistemas Agroflorestais; Brasília: Embrapa Informação Tecnológica, 2006b. p.217-242.

BUCH, A.C.; CORREIA, M.E.F.; TEIXEIRA, D.C.; SILVAFILHO, E.V. Characterization of soil fauna under the influence of mercury atmospheric deposition in Atlantic Forest, Rio de Janeiro, Brazil. Journal of Environmental Sciences, v.32, p.217227, 2015. DOI: https://doi.org/10.1016/j.jes.2015.01.009.

BÜNEMANN, E.K.; BONGIORNO, G.; BAI, Z.; CREAMER, R.E.; DEYN, G. de; GOEDE, R. de; FLESKENS, L.; GEISSEN, V.; KUYPER, T.W.; MÄDER, P.; PULLEMAN, M.; SUKKEL, W.; GROENIGEN, J.W. van; BRUSSAARD, L. Soil quality - a critical review. Soil Biology and Biochemistry, v.120, p.105-125, 2018. DOI: https://doi.org/10.1016/j.soilbio.2018.01.030.

CABALLERO, M.E.L.S. Bionomia de oligochaeta terrestres da região Norte-Ocidental do Estado de São Paulo, Brasil. Ciência e Cultura, v.28, p.762-765, 1976.

CABALLERO, M.E.S. Bionomia dos oligochaeta terrestres da região Norte-Ocidental do Estado de São Paulo. 1973. Tese (Doutorado) - Universidade Estadual Paulista Júlio de Mesquita Filho, São Paulo.

CABALLERO, M.E.S. Influência dos fatores hígricos sobre a biomassa de Pheretima hawayana e Pontoscolex corethrurus (Annelida, Oligochaeta). Zoo Intertrópica, v.2, p.1-11, 1979.

CAMARGO, F.F. Indicadores físicos, químicos e biológicos da qualidade do solo em sistemas agroflorestais agroecológicos na área de preservação ambiental Serra da Mantiqueira, MG. 2016. 241p. Tese (Doutorado) - Universidade Federal de Lavras, Lavras.

CAMARGO, F.F.; SANTOS, A.; CARDOSO, G.B.X.; NADOLNY, H.; ASSUNÇÃO, R.R.; NEGRETTI, T.F.M.; NEGRETTI, B.D.; FROUFE, L.C.M.; BROWN, G.G. Comunidades de minhocas em diferentes tipos de uso do solo localizados na Área de Proteção 
Ambiental da Serra da Mantiqueira-MG. In: ENCONTRO LATINO-AMERICANO DE ECOLOGIA E TAXONOMIA DE OLIGOQUETAS, 5.; SIMPÓSIO ENGENHEIROS EDÁFICOS, FERTILIDADE DO SOLO E TERRA PRETA DE ÍNDIO (TPI), 2015, Curitiba. Anais. [S.1.]: Federação Brasileira de Plantio Direto de Irrigação, 2015. p.63-68. $5^{\circ}$ ELAETAO.

CAMPOS, B.C. de; PESSOA, A.C.S.; FIGUEIREDO, L.G.B.; GOY, C.; VOGT, A.I.; NEUSSER, C.; ANTONIOLLI, Z.I.; GIRACCA, E.M.N. Estudo da mesofauna do solo em espécies vegetais antecedendo milho no sistema de plantio direto. In: CONGRESSO BRASILEIRO DE CIÊNCIA DO SOLO, 26., 1997, Rio de Janeiro. Informação, globalização, uso do solo: anais. Viçosa: SBCS, 1997.

CARDOSO, G.B.X.; NADOLNY, H.; FEIJOO, A.; BROWN, G.G. Earthworm populations in an altitudinal gradient of the coastal Atlantic Rainforest in Paraná State, southern Brazil (Oligochaeta). In: PAVLÍCEK, T.; CARDET, P.; ALMEIDA, M.T.; PASCOAL, C.; CÁSSIO, F. (Ed.). Advances in Earthworm Taxonomy VI (Annelida: Oligochaeta). Heidelberg: Kasparek Verlag, 2014. p.74-86. Proceedings of the $6^{\text {th }}$ International Oligochaeta Taxonomy Meeting $\left(6^{\text {th }}\right.$ IOTM), Palmeira de Faro, April 22-25, 2013.

CARTER, G.S.; BEADLE, L.C. The fauna of the swamps of the Paraguayan Chaco in relation to its environment. III. Respiratory adaptation in the Oligochaeta. Linnean Society's Journal (Zoology), v.37, p.379-386, 1931. DOI: https://doi.org/10.1111/j.1096-3642.1931.tb00468.x.

CATANOZI, G. Análise espacial da macrofauna edáfica sob diferentes condições ambientais dos trópicos úmidos. 2010. 202p. Tese (Doutorado) - Universidade Estadual de Campinas, Campinas.

CLUZEAU, D.; GUERNION, M.; CHAUSSOD, R.; MARTINLAURENT, F.; VILLENAVE, C.; CORTET, J.; RUIZCAMACHO, N.; PERNIN, C.; MATEILLE, T.; PHILIPPOT, L.; BELlidO, A.; ROUGÉ, L.; ARROUAYS, D.; BISPO, A.; PÉRÈS, G. Integration of biodiversity in soil quality monitoring: baselines for microbial and soil fauna parameters for different land-use types. European Journal of Soil Biology, v.49, p.63-72, 2012. DOI: https://doi.org/10.1016/j.ejsobi.2011.11.003.

CORDEIRO, F.C.; DIAS, F. de C.; MERLIM, A. de O.; CORREIA, M.E.F.; AQUINO, A.M. de; BROWN, G. Diversidade da macrofauna invertebrada do solo como indicadora da qualidade do solo em sistema de manejo orgânico de produção. Revista Universidade Rural. Série Ciências da Vida, v.24, p.29-34, 2004.

CORDERO, E.H. Oligoquetos Sudamericanos de la familia Glossoscolecidae II: dos nuevas especies de Rhinodrilus del Nordeste del Brasil. Comunicaciones Zoologicas del Museo de Historia Natural de Montevideo, v.1, p.1-6, 1943.

CORREAA, R.S.; BENTO, M.A.B. Qualidade do substrato minerado de uma área de empréstimo revegetada no Distrito Federal. Revista Brasileira de Ciência do Solo, v.34, p.1435-1443, 2010. DOI: https://doi.org/10.1590/S0100-06832010000400039.

CORREIA, M.E.F.; LIMA, D.A.; FRANCO, A.A.; CAMPELLO, E.F.C.; TAVARES, S.R.L. Comunidades da macrofauna do solo em áreas de floresta secundária de Mata Atlântica no Estado do Rio de Janeiro. In: WORKSHOP O USO DA MACROFAUNA EDÁFICA NA AGRICULTURA DO SÉCULO XXI: A IMPORTÂNCIA DOS ENGENHEIROS DO SOLO, 2003, Londrina. Anais. Londrina: Embrapa Soja, 2003. p.223-224. (Embrapa Soja. Documentos, 224). Organizado por George Gardner Brown, Carlos Fragoso e Lenita Jacob Oliveira.

COSTA, A. da; AlBUQUERQUE, J.A.; COSTA, A. da; PÉRTILE, P.; SILVA, F.R. da. Water retention and availability in soils of the State of Santa Catarina-Brazil: effect of textural classes, soil classes and lithology. Revista Brasileira de Ciência do Solo, v.37, p.1535-1548, 2013. DOI: https://doi.org/10.1590/ s0100-06832013000600010.

COSTA, P. da; COSTA, M.I. da S.; AMARAL, M. da C.; MOURÃO JÚNIOR, M.M. Macrofauna edáfica em sistemas agroflorestais e outros sistemas de uso da terra em Roraima - resultados iniciais. Boa Vista: Embrapa Roraima, 2004. (Embrapa Roraima. Comunicado técnico 18).

CURRY, J.P. Factors affecting the abundance of earthworms in soils. In: EDWARDS, C.A. (Ed.). Earthworm ecology. $2^{\text {nd }}$ ed. Boca Raton: CRC Press, 2004. p.91-113.

DECAËNS, T.; JIMÉNEZ, J.J.; BARROS, E.; CHAUVEL, A.; BLANCHART, E.; FRAGOSO, C.; LAVELLE, P. Soil macrofaunal communities in permanent pastures derived from tropical forest or savanna. Agriculture, Ecosystems and Environment, v.103, p.301-312, 2004. DOI: https://doi.org/10.1016/j.agee.2003.12.005.

DERPSCH, R.; SIDIRAS, N.; ROTH, C.H. Results of studies made from 1977 to 1984 to control erosion by cover crops and no-tillage techniques in Paraná, Brazil. Soil and Tillage Research, v.8, p.253-263, 1986. DOI: https://doi.org/10.1016/01671987(86)90338-7.

DIAS, A.M.; SILVA, R.F. da; MERCANTE, F.M. Caracterização da macrofauna invertebrada do solo sob diferentes fitofisionomias do Pantanal Sul-Mato-Grossense. In: REUNIÃO BRASILEIRA DE FERTILIDADE DO SOLO E NUTRIÇÃO DE PLANTAS, 27.; REUNIÃO BRASILEIRA SOBRE MICORRIZAS, 11.; SIMPÓSIO BRASILEIRO DE MICROBIOLOGIA DO SOLO, 9.; REUNIÃO BRASILEIRA DE BIOLOGIA DO SOLO, 6., 2006, Bonito, MS. A busca das raízes: anais. Dourados: Embrapa Agropecuária Oeste, 2006a. (Embrapa Agropecuária Oeste. Documentos, 82). FERTBIO 2006.

DIAS, P.F.; SOUTO, S.M.; CORREIA, M.E.F.; ROCHA, G.P.; MOREIRA, J.F.; RODRIGUES, K. de M.; FRANCO, A.A. Árvores fixadoras de nitrogênio e macrofauna do solo em pastagem de híbrido de Digitaria. Pesquisa Agropecuária Brasileira, v.41, p.1015-1021, 2006b. DOI: https://doi.org/10.1590/ S0100-204X2006000600018.

DIAS, P.F.; SOUTO, S.M.; CORREIA, M.E.F.; RODRIGUES, K. de M.; FRANCO, A.A. Efeito de leguminosas arbóreas sobre a macrofauna do solo em pastagem de Brachiaria brizantha cv. Marandu. Pesquisa Agropecuária Tropical, v.37, p.38-44, 2007.

DIAS, V.S.; BROSSARD, M.; ASSAD, M.L.L. Macrofauna edáfica invertebrada em áreas de vegetação nativa da região de Cerrados. In: LEITE, L.L.; SAITO, C.H. (Ed.). Contribuição ao conhecimento ecológico do cerrado. Brasília: UnB, 1997. p.168- 
173. Trabalho apresentado no $3^{\circ}$ Congresso de Ecologia do Brasil, Brasília, 1996.

DOUBE, B.M.; SCHMIDT, O. Can the abundance or activity of soil macrofauna be used to indicate the biological health of soils? In: PANKHURST, C.; DOUBE, B.M.; GUPTA, V.V.S.R. (Ed.). Biological indicators of soil health and sustainable productivity. New York: CAB International, 1997. p.265-295.

DRUMOND, M.A.; GUIMARÃES, A.Q.; EL BIZRI, H.R.; GIOVANETTI, L.C.; SEPÚLVEDA, D.G.; MARTINS, R.P. Life history, distribution and abundance of the giant earthworm Rhinodrilus alatus RIGHI 1971: conservation and management implications. Brazilian Journal of Biology, v.73, p.699-708, 2013. DOI: https://doi.org/10.1590/S1519-69842013000400004.

DUNGER, W.; FIEDLER, H.J. Methoden der bodenbiologie. Jena: Gustav Fischer Verlag, 1997. 539p.

EDWARDS, C.A. (Ed.). Earthworm ecology. $2^{\text {nd }}$ ed. Boca Raton: CRC Press, 2004. 441p.

EDWARDS, C.A.; BOHLEN, P.J. Biology and ecology of earthworms. $3^{\text {rd }}$ ed. London: Chapman \& Hall, 1996. 426p.

EDWARDS, C.A.; LOFTY, J.R. Nitrogenous fertilizers and earthworm populations in agricultural soils. Soil Biology and Biochemistry, v.14, p.515-521, 1982. DOI: https://doi.org/10.1016/0038-0717(82)90112-2.

FAO. Food and Agricultural Organization of the United Nations. World reference base for soil resources 2014: international soil classification system for naming soils and creating legends for soil maps. Rome: FAO, 2015. 192p. (FAO. World Soil Resources Report 106).

FELLER, C.; BEARE, M.H. Physical control of soil organic matter dynamics in the tropics. Geoderma, v.79, p.69-116, 1997. DOI: https://doi.org/10.1016/S0016-7061(97)00039-6.

FERNANDES, J. de O. Minhocas como indicadores ambientais em ecossistemas agrícolas. 2009. 86p. Dissertação (Mestrado) Universidade Estadual de Londrina, Londrina.

FERNANDES, J.O.; UEHARA-PRADO, M.; BROWN, G.G. Minhocas exóticas como indicadoras de perturbação antrópica em áreas de Floresta Atlântica. Acta Zoológica Mexicana, v.26, p.211-217, 2010. Número especial 2. DOI: https://doi.org/10.21829/ azm.2010.262889.

FERREIRA, C. dos R.; CORREIA, M.E.F.; REZENDE, A.S. de; OLIVEIRA, R.S. de. Composição da macrofauna do solo em dois fragmentos florestais no município de Itaboraí - RJ. In: REUNIÃO BRASILEIRA DE FERTILIDADE DO SOLO E NUTRIÇÃO DE PLANTAS, 30; REUNIÃO BRASILEIRA SOBRE MICORRIZAS, 14.; SIMPÓSIO BRASILEIRO DE MICROBIOLOGIA DO SOLO, 12.; REUNIÃO BRASILEIRA DE BIOLOGIA DO SOLO, 9.; SIMPÓSIO SOBRE SELÊNIO NO BRASIL, 1., 2012, Maceió. A responsabilidade socioambiental da pesquisa agrícola: anais. Viçosa: SBCS, 2012. FERTBIO 2012.

FERREIRA, S. de A. Avaliação visual da estrutura e macrofauna edáfica em sistemas de uso do solo no subtrópico brasileiro. 2015. 42p. Dissertação (Mestrado) - Universidade Federal do Paraná, Curitiba.
FRANCHINI, J.C.; DEBIASI, H.; HOFFMANN-CAMPO, C.B.; PASINI, A.; SACOMAN, A.; SILVA, J.R. da; FRANÇA, C.; CARRARA, R. Abundância e diversidade da macrofauna do solo em diferentes fases de um sistema de integração lavoura-pecuária no Arenito Paranaense. In: WORKSHOP INTEGRAÇÃO LAVOURA-PECUÁRIA-FLORESTA NA EMBRAPA, 2009, Brasília. Anais. Brasília: Embrapa, 2009.

FRANCO, A.L.C.; BARTZ, M.L.C.; CHERUBIN, M.R.; BARETTA, D.; CERRI, C.E.P.; FEIGL, B.J.; WALL, D.H.; DAVIES, C.A.; CERRI, C.C. Loss of soil (macro)fauna due to the expansion of Brazilian sugarcane acreage. Science of the Total Environment, v.563-564, p.160-168, 2016. DOI: https://doi.org/10.1016/j.scitotenv.2016.04.116.

FREITAS, M.P. Flutuação populacional de oligochaeta edáficos em hortas sob sistemas convencional e orgânico no município de Canoinhas/SC. 2007. 61p. Dissertação (Mestrado) - Universidade Federal do Paraná, Curitiba.

FRÜND, H.-C.; GRAEFE, U.; TISCHER, S. Earthworms as bioindicators of soil quality. In: KARACA, A. (Ed.). Biology of earthworms. Berlin: Springer, 2011. p.261-278. (Soil Biology, 24). DOI: https://doi.org/10.1007/978-3-642-14636-7_16 .

GAVRILOV, K. Oligochaeta. In: HURLBERT, S.H.; RODRIGUEZ, G.; SANTOS, N.D. dos (Ed.). Aquatic biota of Tropical South America: part 2: Anarthropoda. San Diego: San Diego State University, 1981. p.170-190.

GIRACCA, E.M.N. Efeito do calcário em atributos biológicos do solo. 2005. 61p. Tese (Doutorado) - Universidade Federal de Santa Maria, Santa Maria.

GOIS, D.T. de; SANTOS, J.C.P.; ALVES, M.V.; PRANDO, A.M.; TOLEDO, G.C. de; SOUZA, D.G. de. Avaliação da macrofauna edáfica em áreas de reflorestamento de pinus com diferentes tipos de uso, no Litoral Catarinense. In: CONGRESSO BRASILEIRO DE CIÊNCIA DO SOLO, 31., 2007, Gramado. Conquistas e desafios da Ciência do Solo brasileira: anais. [Porto Alegre]: SBCS, Núcleo Regional Sul, 2007.

GORTE, T. Qualidade do solo em sistema plantio direto. 2016. 141p. Dissertação (Mestrado) - Universidade Positivo, Curitiba.

GRAEFE, U.; BEYLICH, A. Critical values of soil acidification for annelid species and the decomposer community. Newsletter on Enchytraeidae, v.8, p.51-55, 2003.

GUERRA, R.T. Earthworm activity in forest and savanna soils near Boa Vista, Roraima, Brazil. Acta Amazonica, v.24, p.303308, 1994a. DOI: https://doi.org/10.1590/1809-43921994243308.

GUERRA, R.T. Sobre a comunidade de minhocas (Annelida, Oligochaeta) do campus da Universidade Federal do Acre, Rio Branco (AC), Brasil. Revista Brasileira de Biologia, v.54, p.593601, 1994b.

GUERRA, R.T.; SILVA, E.G. da. Estudo das comunidades de minhocas (Annelida, Oligochaeta) em alguns ambientes terrestres do Estado da Paraíba. Revista Nordestina de Biologia, v.9, p.209-223, 1994.

GUILD, W.J.M. Studies on the relationship between earthworms and soil fertility. Annals of Applied Biology, v.35, p.181-192, 1948. DOI: https://doi.org/10.1111/j.1744-7348.1948.tb07360.x. 
HARADA, A.Y.; BANDEIRA, A.G. Estratificação e densidade de invertebrados em solo arenoso sob floresta primária e plantios arbóreos na Amazônia Central durante a estação seca. Acta Amazonica, v.24, p.103-118, 1994. DOI: https://doi. org/10.1590/1809-43921994242118.

HIPÓLITO, A.W.; SCHIAVON, G. de A.; CARDOSO, J.H. Análise de diversidade da macrofauna do solo em sistemas agroflorestais. Cadernos de Agroecologia, v.10, 2015.

HUERTA, E.; DIOS, D. de la O.-D.; NUNCIO, G. Incremento de la fertilidad del suelo mediante el uso de lombrices de tierra (Glossoscolecidae y Acanthodrilidae) y leguminosas (Arachis pintoi) en un suelo de traspatio. Ciencia Ergo Sum, v.14, p.172176, 2007.

HUERTA, E.; FRAGOSO, C.; BAROIS, I.; LAVELLE, P. Enhancement of growth and reproduction of the tropical earthworm Polypheretima elongata (Megascolecidae) by addition of Zea mays and Mucuna pruriens var. utilis litter to the soil. European Journal of Soil Biology, v.41, p.45-53, 2005. DOI: https://doi.org/10.1016/j.ejsobi.2005.01.002.

IBGE. Instituto Brasileiro de Geografia e Estatística. Biomas e Sistema Costeiro-Marinho do Brasil: compatível com a escala 1:250 000. Rio de Janeiro, 2019. 161p. (Relatórios metodológicos, v.45).

IBGE. Instituto Brasileiro de Geografia e Estatística. Manual técnico da vegetação brasileira: sistema fitogeográfico: inventário das formações florestais e campestres: técnicas e manejo de coleções botânicas: procedimentos para mapeamentos. 2.ed. rev. e ampl. Rio de Janeiro, 2012. 271p. (Manuais Técnicos em Geociências, 1).

IBGE. Instituto Brasileiro de Geografia e Estatística. Manual técnico de pedologia. 2.ed. Rio de Janeiro, 2007. 316p. (Manuais Técnicos em Geociências, 4).

IBGE. Instituto Brasileiro de Geografia e Estatística. Produção da Extração Vegetal e da Silvicultura. Rio de Janeiro, 2015. v.30, 48p.

ISO. International Organization for Standardization. ISO 112683:2014: Soil quality: effects of pollutants on earthworms: Part 3: Guidance on the determination of effects in field situations. Brussels, 2015.

ISO. International Organization for Standardization. ISO 236111:2018: Soil quality: sampling of soil invertebrates: Part 1 : Handsorting and extraction of earthworms. $2^{\text {nd }}$ ed. [Brussels], 2018.

JARDEVESKI, R.; PORFÍRIO-DA-SILVA, V. Minhocas em uma pastagem arborizada na região noroeste do Estado do Paraná, Brazil. Boletim de Pesquisa Florestal, v.51, p.17-31, 2005.

JEFFERY, S.; GARDI, C.; JONES, A.; MONTANARELLA, L.; MARMO, L.; MIKO, L.; RITZ, K.; PERES, G.; RÖMBKE, J.; VAN DER PUTTEN, W.H. European atlas of soil biodiversity. Luxembourg: EU, 2010. 128p.

JIMÉNEZ, J.J.; LAVELLE, P.; DECAËNS, T. The efficiency of soil hand-sorting in assessing the abundance and biomass of earthworm communities. Its usefulness in population dynamics and cohort analysis studies. European Journal of
Soil Biology, v.42, p.S225-S230, 2006. Supplement 1. DOI: https://doi.org/10.1016/j.ejsobi.2006.07.031.

JONES, C.G.; LAWTON, J.H.; SHACHAK, M. Organisms as ecosystem engineers. Oikos, v.69, p.373-386, 1994. DOI: https://doi.org/10.2307/3545850.

JOUQUET, P.; BLANCHART, E.; CAPOWIEZ, Y. Utilization of earthworms and termites for the restoration of ecosystem functioning. Applied Soil Ecology, v.73, p.34-40, 2014. DOI: https://doi.org/10.1016/j.apsoil.2013.08.004.

KALE, R.D.; KARMEGAM, N. The role of earthworms in tropics with emphasis on Indian ecosystems. Applied and Environmental Soil Science, v.2010, art.ID414356, 2010. DOI: https://doi.org/10.1155/2010/414356.

KEMPER, B.; DERPSCH, R. Estudos sobre susceptibilidade dos solos a erosão e métodos de proteção do solo no Estado do Paraná. In: ENCONTRO NACIONAL DE PESQUISA SOBRE CONSERVAÇÃO DO SOLO, 3., 1980, Recife. Anais. Recife: SBCS: UFRPE, 1981.

KEMPER, B.; DERPSCH, R. Results of studies made in 1978 and 1979 to control erosion by cover crops and no-tillage techniques in Paraná, Brazil. Soil and Tillage Research, v.1, p.253-267, 1980/1981. DOI: https://doi.org/10.1016/0167-1987(80)90028-8.

KLENK, L.A. Macrofauna invertebrada edáfica em pastagem com pastoreio rotativo sob diferentes preparos orgânicos em condições subtropicais no Sul do Brasil. 2010. 54p. Dissertação (Mestrado) - Universidade Federal do Paraná, Curitiba.

KLOK, C.; FABER, J.; HEIJMANS, G.; BODT, J.; VAN DER HOUT, A. Influence of clay content and acidity of soil on development of the earthworm Lumbricus rubellus and its population level consequences. Biology and Fertility of Soils, v.43, p.549-556, 2007. DOI: https://doi.org/10.1007/s00374-0060135-0.

KNAPPER, C.F.U.; PORTO, R.P. Ocorrência de oligochaetas nos solos do Rio Grande do Sul. Acta Biologica Leopoldensia, v.1, p.137-166, 1979.

KRABBE, E.L.; DRIEMEYER, D.J.; ANTONIOLLI, Z.I.; GIRACCA, E.M.N. Avaliação populacional de oligoquetas e características físicas do solo em diferentes sistemas de cultivo. Ciência Rural, v.23, p.21-26, 1993. DOI: https://doi.org/10.1590/ S0103-84781993000100005.

LAOSSI, K.-R.; BAROT, S.; CARVALHO, D.; DESJARDINS, T.; LAVELLE, P.; MARTINS, M.; MITJA, D.; RENDEIRO, A.C.; ROUSSEAU, G.; SARRAZIN, M.; VELASQUEZ, E.; GRIMALDI, M. Effects of plant diversity on plant biomass production and soil macrofauna in Amazonian pastures. Pedobiologia, v.51, p.397-407, 2008. DOI: https://doi.org/10.1016/j.pedobi.2007.11.001.

LAVELLE, P. Assessing the abundance and role of invertebrate communities in tropical soils: aims and methods. Journal of African Zoology, v.102, p.275-283, 1988a.

LAVELLE, P. Earthworm activities and the soil system. Biology and Fertility of Soils, v.6, p.237-251, 1988b. DOI: https://doi.org/10.1007/BF00260820. 
LAVELLE, P. The soil fauna of tropical savannas. II. The earthworms. In: BOURLIERE, F. (Ed.). Tropical savannas. Amsterdam: Elsevier, 1983. p.485-504. (Ecosystems of the world, $13)$.

LAVELLE, P.; BAROIS, I.; CRUZ, I.; FRAGOSO, C.; HERNANDEZ, A.; PINEDA, A.; RANGEL, P. Adaptive strategies of Pontoscolex corethrurus (Glossoscolecidae, Oligochaeta), a peregrine geophagous earthworm of the humid tropics. Biology and Fertility of Soils, v.5, p.188-194, 1987. DOI: https://oi.org/10.1007/BF00256899.

LAVELlE, P.; BARROS, E.; BLANCHART, E.; BROWN, G.; DESJARDINS, T.; MARIANI, L.; ROSSI, J.-P. SOM management in the tropics: why feeding the soil macrofauna? Nutrient Cycling in Agroecosystems, v.61, p.53-61, 2001.

LAVELlE, P.; BIGNELL, D.; LEPAGE, M.; WOLTERS, V.; ROGER, P.; INESON, P.; HEAL, O.W.; DHILlION, S. Soil function in a changing world: the role of invertebrate ecosystem engineers. European Journal of Soil Biology, v.33, p.159-193, 1997.

LAVELLE, P.; BLANCHART, E.; MARTIN, A.; MARTIN, S.; SPAIN, A.; TOUTAIN, F.; BAROIS, I.; SCHAEFER, R. A hierarchical model for decomposition in terrestrial ecosystems: application to soils of the humid tropics. Biotropica, v.25, p.130150, 1993. DOI: https://doi.org/10.2307/2389178.

LAVELLE, P.; CHAUVEL, A.; FRAGOSO, C. Faunal activity in acid soils. In: DATE, R.A.; GRUNDON, N.J.; RAYMENT, G.E.; PROBERT, M.E. (Ed.). Plant soil interactions at low pH. Netherlands: Kluwer Academic Publishers, 1995a. p.201-211. DOI: https://doi.org/10.1007/978-94-011-0221-6_29.

LAVELlE, P.; KOHLMANN, B. Étude quantitative de la macrofaune du sol dans une forêt tropicale humide du Mexique (Bonampak, Chiapas). Pedobiologia, v.27, p.377-393, 1984.

LAVELLE, P.; LAPIED, E. Endangered earthworms of Amazonia: an homage to Gilberto Righi. Pedobiologia, v.47, p.419-427, 2003. DOI: https://doi.org/10.1078/0031-4056-00207.

LAVELLE, P.; LATTAUD, C.; TRIGO, D.; BAROIS, I. Mutualism and biodiversity in soils. Plant and Soil, v.170, p.23-33, 1995b. DOI: https://doi.org/10.1007/BF02183052.

LAVELlE, P.; MAURY, M.E.; SERRANO, V. Estudio cuantitativo de la fauna del suelo en la región de Laguna Verde, Veracruz: Epoca de lluvias. Instituto de Ecología de México, v.6, p.75-105, 1981.

LAVELLE, P.; SPAIN, A. V. Soil ecology. [Dordrecht]: Kluwer Academic Publishers, 2001. 654p.

LEE, K.E. Earthworms: their ecology and relationships with soils and land use. Sydney: Academic Press, 1985. 411p.

LIMA, A.C.R. de; BRUSSAARD, L. Earthworms as soil quality indicators: local and scientific knowledge in rice management systems. Acta Zoológica Mexicana, v.26, p.109-116, 2010. DOI: https://doi.org/10.21829/azm.2010.262881.

LIMA, D. de; SANTOS, A.M.B. dos; PASINI, A.; BODNAR, A.; GARCIA, A.; OLIVEIRA, A.B. de; CORRÊA-FERREIRA, B.S.; GOMES, C.R.; SEIXAS, C.D.S.; TORRES, E.; PELIZZARO, E.C.; OLIVEIRA, F.F. de; ADEGAS, F.S.; BROWN, G.G.
Produção integrada de soja. In: ZAMBOLIM, L.; NASSER, L.C.B.; ANDRIGUETO, J.R.; TEIXEIRA, J.M.A.; KOSOSKI, A.R.; FACHINELLO, J.C. (Org.). Produção integrada no Brasil: agropecuária sustentável: alimentos seguros. Brasília: Ministério da Agricultura, Pecuária e Abastecimento, 2008/2009. p.813-848.

LIMA, H.V. de; OLIVEIRA, T.S. de; OLIVEIRA, M.M. de; MENDONÇA, E. de S.; LIMA, P.J.B.F. Indicadores de qualidade do solo em sistemas de cultivo orgânico e convencional no semi-árido cearense. Revista Brasileira de Ciência do Solo, v.31, p.1085-1098, 2007. DOI: https://doi.org/10.1590/S010006832007000500024.

LIMA, O.G. de. Indicadores físicos, químicos e biológicos da qualidade do solo em plantios florestais e floresta ombrófila mista na Embrapa Florestas, Colombo-PR. 2011. 67p. Dissertação (Mestrado) - Universidade Federal do Paraná, Curitiba.

LIMA, S.S. de. Impacto do manejo agroflorestal sobre a dinâmica de nutrientes e a macrofauna invertebrada nos compartimentos serapilheira-solo em área de transição no norte do Piauí. 2008. 78p. Dissertação (Mestrado) - Universidade Federal do Piauí, Teresina.

LIMA, S.S. de; AQUINO, A.M. de; LEITE, L.F.C.; VELÁSQUEZ, E.; LAVELLE, P. Relação entre macrofauna edáfica e atributos químicos do solo em diferentes agroecossistemas. Pesquisa Agropecuária Brasileira, v.45, p.322-331, 2010. DOI: https://doi.org/10.1590/S0100-204X2010000300013.

LINS-TEIXEIRA, A.; TAPIA-CORAL, S.C.; LUIZÃO, F.J.; MORAIS, J.W.; WANDELLI, E. Macro-invertebrados do solo em capoeiras trituradas usadas como alternativa ao uso do fogo no Assentamento Tarumã-Mirim, Amazonas. In: CONGRESSO DE ECOLOGIA DO BRASIL, 8., 2007, Caxambu. Ecologia no tempo de mudanças globais: anais. Caxambu: SEB, 2007. Available at: <http://www.seb-ecologia.org.br/revistas/indexar/ anais/viiiceb/pdf/251.pdf>. Accessed on: July 232015.

LOURENTE, E.R.P.; SILVA, R.F. da; SILVA, D.A. da; MARCHETTI, M.E.; MERCANTE, F.M. Macrofauna edáfica e sua interação com atributos químicos e físicos do solo sob diferentes sistemas de manejo. Acta Scientiarum. Agronomy, v.29, p.17-22, 2007. DOI: https://doi.org/10.4025/actasciagron. v29i1.60.

LUIZÃO, R.C.C.; BARROS, E.; LUIZÃO, F.J.; ALFAIA, S.S. Soil biota and nutrient dynamics through litterfall in agroforestry system in Rondônia, Amazônia, Brazil. In: INTERNATIONAL TECHNICAL WORKSHOP ON BIOLOGICAL MANAGEMENT OF SOIL ECOSYSTEMS FOR SUStAinABLE AGRICUlTURE,. 2002, Londrina. Program, abstracts, and related documents. Londrina: Embrapa Soja, 2002. p.49-53. (Embrapa Soja. Documentos 182). Organization: George G. Brown, Mariangela Hungria, Lenita Jacob Oliveira, Sally Bunning and Adriana Montañez.

MA, W.-C.; BRUSSAARD, L.; RIDDER, J.A. de. Long-term effects of nitrogenous fertilizers on grassland earthworms (Oligochaeta: Lumbricidae): their relation to soil acidification. Agriculture, Ecosystems and Environment, v.30, p.71-80, 1990. DOI: https://doi.org/10.1016/0167-8809(90)90184-F. 
MADEIRA, C.L.; ALVARENGA, M.I.N.; PINHEIRO, L.B.A. Efeito da produção de fitomassa na fauna de solo sob lavoura cafeeira em sub-bosque de araucária (Araucaria angustifolia L.). In: CONGRESSO BRASILEIRO DE CIÊNCIA DO SOLO, 33., 2011, Uberlândia. Solos nos biomas brasileiros: sustentabilidade e mudanças climáticas: anais. Uberlândia: SBCS; UFU: ICIAG, 2011.

MAFRA, Á.L.; ALBUQUERQUE, J.A.; MEDEIROS, J.C.; DALLA ROSA, J.; FONTOURA, S.M.V.; COSTA, F. de S.; BAYER, C. Manejo do solo e fauna edáfica em experimento de longa duração na região de Guarapuava-PR. In: REUNIÃO BRASILEIRA DE MANEJO E CONSERVAÇÃO DO SOLO E DA ÁGUA, 14., 2002, Cuiabá. Os (des) caminhos do uso da água na agricultura brasileira: anais. Cuiabá: SBCS: UFMT, 2002.

MALAVOLTA, E. Manual de nutrição mineral de plantas. São Paulo: Agronômica Ceres, 2006. 631p.

MARCHAND, L.; BRUNEL-MUGUET, S.; LAMY, I.; MENCH, M.; PELOSI, C. Modulation of trace element bioavailability for two earthworm species after biochar amendment into a contaminated technosol. Ecotoxicology, v.26, p.1378-1391, 2017. DOI: https://doi.org/10.1007/s10646-017-1862-8.

MARCHÃO, R.L.; LAVELLE, P.; CELINI, L.; BALBINO, L.C.; VILELA, L.; BECQUER, T. Soil macrofauna under integrated crop-livestock systems in a Brazilian Cerrado Ferralsol. Pesquisa Agropecuária Brasileira, v.44, p.1011-1020, 2009. DOI: https://doi.org/10.1590/S0100-204X2009000800033.

MARCHÃO, R.L.; VILELA, L.; BENITO, N.P.; SANTOS, B.D. dos. Macrofauna edáfica sob diferentes sistemas de manejo num Neossolo Quartzarênico do Cerrado do oeste baiano. In: SIMPÓSIO NACIONAL CERRADO, 9.; SIMPÓSIO INTERNACIONAL SAVANAS TROPICAIS, 2., 2008, Brasília. Desafios e estratégias para o equilíbrio entre sociedade, agronegócio e recursos naturais: anais. Planaltina: Embrapa Cerrados, 2008a.

MARCHÃO, R.L.; VILELA, L.; SANTOS JUNIOR, J. de D.G.; SÁ, M.A.C. de; BERGAMASCHI, L.C.; BORTONCELLO, L.R. Impacto de sistemas agrícolas nos atributos físicos, químicos e macrofauna num Latossolo do oeste baiano. Planaltina: Embrapa Cerrados, 2008b. 30p.

MARCHINI, D. de C.; ALVES, M.C.; PINTO, C.C.; OLIVEIRA, C.O.E.; SOUTO FILHO, S.N.; ARRUDA, O.G. de; BONINI, C. dos S.B. Uso da macrofauna como indicador biológico de um Latossolo Vermelho em recuperação. In: CONGRESSO BRASILEIRO DE CIÊNCIA DO SOLO, 33., 2011, Uberlândia. Solos nos biomas brasileiros: sustentabilidade e mudanças climáticas: anais. Uberlândia: SBCS: UFU: ICIAG, 2011.

MARCHIORI, A.C.C. Sustentabilidade de sistemas de produção de gengibre (Zingiber officinale R.) consorciado com leguminosas no Bioma Mata Atlântica em Ubatuba. 2008. 150p. Tese (Doutorado) - Universidade Federal Rural do Rio de Janeiro, Seropédica.

MARICHAL, R.; MARTINEZ, A.F.; PRAXEDES, C.; RUIZ, D.; CARVAJAL, A.F.; OSZWALD, J.; HURTADO, M. del P.; BROWN, G.G.; GRIMALDI, M.; DESJARDINS, T.; SARRAZIN, M.; DECAËNS, T.; VELASQUEZ, E.; LAVELLE, P. Invasion of Pontoscolex corethrurus (Glossoscolecidae, Oligochaeta) in landscapes of the Amazonian deforestation arc. Applied Soil Ecology, v.46, p.443-449, 2010. DOI: https://doi.org/10.1016/j. apsoil.2010.09.001.

MARQUES, D.M.; SILVA, L.M. da. Macrofauna edáfica em solos submetidos a diferentes sistemas de manejo, no Município de Campos Gerais - MG. 2011. 57p. Trabalho de Conclusão de Curso (Bacharelado) - Faculdade de Ciências e Tecnologias de Campos Gerais, Campos Gerais.

MARTIN, A.; MARIOTTI, A.; BALESDENT, J.; LAVELLE, P. Soil organic matter assimilation by a geophagous tropical earthworm based on delta ${ }^{13} \mathrm{C}$ measurements. Ecology, v.73, p.118128, 1992. DOI: https://doi.org/10.2307/1938725.

MARTIN, N.A. Earthworm biomass: influence of gut content and formaldehyde preservation on live-to-dry weight ratios of three common species of pasture lumbricidae. Soil Biology and Biochemistry, v.18, p.245-250, 1986. DOI: https://doi. org/10.1016/0038-0717(86)90056-8.

MASCHIO, W. População de minhocas em plantios de Eucalyptus spp. e efeitos de Pontoscolex corethrurus (Glossoscolecidae) e Amynthas gracilis (Megascolecidae) sobre o crescimento de mudas de Eucalyptus spp. em casa de vegetação. 2012. 47p. Dissertação (Mestrado) - Universidade Federal do Paraná, Curitiba.

MASCHIO, W.; BROWN, G.; SEOANE, C.E.; FROUFE, L.C.M. Abundância e diversidade de minhocas em agroecossistemas da Mata Atlântica nos municípios do Litoral Paranaense - Morretes e Antonina. In: ENCONTRO LATINO-AMERICANO DE ECOLOGIA E TAXONOMIA DE OLIGOQUETAS, 4., 2010, Curitiba. Minhocas como bioindicadoras ambientais: princípios e práticas: anais. Colombo: Embrapa Florestas, 2010. (Embrapa Florestas. Documentos, 199). Editores: George Gardner Brown, Cíntia Carla Niva, Klaus Dieter Sautter, Amarildo Pasini, Mac A. Callaham Jr. e Renato Marques. ELAETAO 4.

MASCHIO, W.; VEZZANI, F.M.; BROWN, G.G. Earthworm populations in Eucalyptus spp. plantations at Embrapa Forestry, Brazil(Oligochaeta). In: PAVLÍČEK, T.; CARDET, P.; ALMEIDA, M.T.; PASCOAL, C.; CÁSSIO, F. (Ed.). Advances in Earthworm Taxonomy VI (Annelida: Oligochaeta). Heidelberg: Kasparek Verlag, 2014. p.114-126. Proceedings of the $6^{\text {th }}$ International Oligochaeta Taxonomy Meeting ( $6^{\text {th }}$ IOTM), Palmeira de Faro, April 22-25, 2013.

MATHIEU, J.; GRIMALDI, M.; JOUQUET, P.; ROULAND, C.; LAVELLE, P.; DESJARDINS, T.; ROSSI, J.-P. Spatial patterns of grasses influence soil macrofauna biodiversity in Amazonian pastures. Soil Biology and Biochemistry, v.41, p.586-593, 2009. DOI: https://doi.org/10.1016/j.soilbio.2008.12.020.

MENDES, R.R.; GOI, S.R.; AZEVEDO, R.A.B. de. Densidade de minhocas em sistema agroflorestal manejado com leguminosas fixadoras de nitrogênio. In: REUNIÃO BRASILEIRA DE FERTILIDADE DO SOLO E NUTRIÇÃO DE PLANTAS, 29; REUNIÃO BRASILEIRA SOBRE MICORRIZAS, 13.; SIMPÓSIO BRASILEIRO DE MICROBIOLOGIA DO SOLO, 11.; REUNIÃO BRASILEIRA DE BIOLOGIA DO SOLO, 8., 2010, Guarapari. Fontes de nutrientes e produção agrícola: modelando o futuro: anais. Viçosa: SBCS, 2010. FERTBIO 2010. 
MENEZES, C.E.G. Integridade de paisagem, manejo e atributos do solo no médio Vale do Paraíba do Sul, PinheiralRJ. 2008. 164p. Tese (Doutorado) - Universidade Federal Rural do Rio de Janeiro, Seropédica.

MENEZES, C.E.G.; CORREIA, M.E.F.; PEREIRA, M.G.; BATISTA, I.; RODRIGUES, K. de M.; COUTO, W.H.; ANJOS, L.H.C. dos; OLIVEIRA, I.P. de. Macrofauna edáfica em estádios sucessionais de Floresta Estacional Semidecidual e pastagem mista em Pinheiral (RJ). Revista Brasileira de Ciências do Solo, v.33, p.1647-1656, 2009. DOI: https://doi.org/10.1590/S010006832009000600013.

MERLIM, A. de O. Macrofauna edáfica em ecossistemas preservados e degradados de araucária no Parque Estadual de Campos do Jordão, SP. 2005. 103p. Dissertação (Mestrado) Escola Superior de Agricultura Luiz de Queiroz, Universidade de São Paulo, Piracicaba.

MERLIM, A. de O.; GUERRA, J.G.M.; JUNQUEIRA, R.M.; AQUINO, A.M. de. Soil macrofauna in cover crops of figs grown under organic management. Scientia Agricola, v.62, p.57-61, 2005. DOI: https://doi.org/10.1590/S0103-90162005000100011.

MISRA, M.K.; TRIPATHY, P.C. Effect of nitrogen fertilizer on plant and earthworm production in a tropical grassland in Orissa. Tropical Ecology, v.29, p.61-72, 1988.

MOTTA, A.C.V.; MELO, V. de F. Química dos solos ácidos. In: MELO, V. de F.; ALLEONI, L.R.F. (Ed.). Química e mineralogia do solo: parte II: aplicações. Viçosa: Sociedade Brasileira de Ciência do Solo, 2009. v.2, p.313-371.

MOURA, E.G.; AGUIAR, A. das C.F.; PIEDADE, A.R.; ROUSSEAU, G.X. Contribution of legume tree residues and macrofauna to the improvement of abiotic soil properties in the eastern Amazon. Applied Soil Ecology, v.86, p.91-99, 2015. DOI: https://doi.org/10.1016/j.apsoil.2014.10.008.

MYERS, N.; MITTERMEIER, R.A.; MITTERMEIER, C.G.; FONSECA, G.A.B. da; KENT, J. Biodiversity hotspots for conservation priorities. Nature, v.403, p.853-858, 2000. DOI: https://doi.org/10.1038/35002501.

NADOLNY, H. Estado da arte das minhocas como bioindicadoras da qualidade dos solos brasileiros. 2017. 135p. Tese (Doutorado) - Universidade Federal do Paraná, Curitiba.

NADOLNY, H.; SANTOS, A.; DEMETRIO, W.; FERREIRA, T.; MAIA, L. dos S.; CONRADO, A.C.;BARTZ, M.; GARRASTAZU, M.; SILVA, E. da; BARETTA, D.; PASINI, A.; VEZZANI, F.; SOUSA, J.P.; CUNHA, L.; MATHIEU, J.; LAVELLE, P.; RÖMBKE, J.; BROWN, G. Data from: recommendations for assessing earthworm populations in Brazilian ecosystems. Dryad Dataset, v.13, 2020. DOI: https://doi.org/10.5061/dryad.4md0s64.

NUNES, D.H. Espécies de minhocas em ecossistemas degradados de Jaguapitã-PR. 2006. 71p. Dissertação (Mestrado) - Universidade Estadual de Londrina, Londrina.

NUNES, D.H.; PASINI, A.; BENITO, N.P.; BROWN, G.G. Minhocas como bioindicadoras da qualidade ambiental. Um estudo de caso na região de Jaguapitã, PR, Brasil. In: BROWN, G.G.; FRAGOSO, C. (Ed.). Minhocas na América Latina: biodiversidade e ecologia. Londrina: Embrapa Soja, 2007. p.467480 .
OLIVEIRA FILHO, L.C.I. de. Produção de alface e rabanete, sob adubação orgânica em ambiente protegido. 2009. 66p. Dissertação (Mestrado) - Universidade Federal de Pelotas, Pelotas.

OLIVEIRA, C.C. de. Inferência ambiental do sombreamento da araucária (Araucaria angustifolia L.) na lavoura cafeeira. 2012. 70p. Dissertação (Mestrado) - Universidade Federal de Itajubá, Itajubá.

ORTEGA-CALVO, J.-J.; HARMSEN, J.; PARSONS, J.R.; SEMPLE, K.T.; AITKEN, M.D.; AJAO, C.; EADSFORTH, C.; GALAY-BURGOS, M.; NAIDU, R.; OLIVER, R.; PEIJNENBURG, W.J.G.M.; RÖMBKE, J.; STRECK, G.; VERSONNEN, B. From bioavailability science to regulation of organic chemicals. Environmental Science \& Technology, v.49, p.10255-10264, 2015. DOI: https://doi.org/10.1021/acs. est. 5 b02412.

OTSUBO, A.A.; MERCANTE, F.M.; SILVA, R.F. da; AQUINO, A.M. de; ARAUJO, H.S. de. Cultivo de mandioca em plantio direto e sua influência na dinâmica da biota do solo e na produtividade da cultura. In: REUNIÃO BRASILEIRA DE FERTILIDADE DO SOLO E NUTRIÇÃO DE PLANTAS, 25.; REUNIÃO BRASILEIRA SOBRE MICORRIZAS, 9.; SIMPÓSIO BRASILEIRO DE MICROBIOLOGIA DO SOLO, 7.; REUNIÃO BRASILEIRA DE BIOLOGIA DO SOLO, 4., 2002, Rio de Janeiro. Agricultura: bases ecológicas para o desenvolvimento social e econômico sustentado: [anais]. [Rio de Janeiro]: SBCS: SBM: UFRRJ: Embrapa Solos; [Seropédica]: Embrapa Agrobiologia, 2002. FERTBIO 2002.

PAOLETTI, M.G.; BUSCARDO, E.; VANDERJAGT, D.J.; PASTUSZYN, A; PIZZOFERRATO, L.; HUANG, Y.-S.; CHUANG, L.-T.; MILlSON, M.; CERDA, H.; TORRES, F.; GLEW, R.H. Nutrient content of earthworms consumed by Ye'Kuana Amerindians of the Alto Orinoco of Venezuela. Proceedings of the Royal Society B - Biological Sciences, v.270, p.249-257, 2003. DOI: https://doi.org/10.1098/rspb.2002.2141.

PASINI, A.; FONSECA, I.C.B.; BROSSARD, M.; GUIMARÃES, M. de F. Macrofauna invertebrada do solo em pastagens no cerrado de Uberlândia, MG, Brasil. In: WORKSHOP O USO DA MACROFAUNA EDÁFICA NA AGRICULTURA DO SÉCULO XXI: A IMPORTÂNCIA DOS ENGENHEIROS DO SOLO, 2003, Londrina. Anais. Londrina: Embrapa Soja, 2003. p.160166. (Embrapa Soja. Documentos, 224). Organizado por George Gardner Brown, Carlos Fragoso e Lenita Jacob Oliveira.

PASQUALIN, L.A. Influência da vinhaça e do método de colheita sobre a macrofauna edáfica na cultura da canade-açúcar. 2009. 89p. Dissertação (Mestrado) - Universidade Federal do Paraná, Curitiba.

PASQUALIN, L.A.; DIONÍSIO, J.A.; ZAWADNEAK, M.A.C.; MARÇAL, C.T. Macrofauna edáfica em lavouras de cana-deaçúcar e mata no noroeste do Paraná - Brasil. Semina: Ciências Agrárias, v.33, p.7-18, 2012. DOI: https://doi.org/10.5433/16790359.2012v33n1p7.

PEIXOTO, R.T.G.; MAROCHI, A.I. A influência da minhoca Pheretima sp. nas propriedades de um Latossolo Vermelho Escuro álico e no desenvolvimento de culturas em sistema de 
plantio direto, em Arapoti - PR. Revista Plantio Direto, v.35, p.23-25, 1996.

PELOSI, C.; BAROT, S.; CAPOWIEZ, Y.; HEDDE, M.; VANDENBULCKE, F. Pesticides and earthworms. A review. Agronomy for Sustainable Development, v.34, p.199-228, 2014. DOI: https://doi.org/10.1007/s13593-013-0151-z.

PELOSI, C.; BERTRAND, M.; CAPOWIEZ, Y.; BOIZARD, H.; ROGER-ESTRADE, J. Earthworm collection from agricultural fields: comparisons of selected expellants in presence/absence of hand-sorting. European Journal of Soil Biology, v.45, p.176-183, 2009. DOI: https://doi.org/10.1016/j.ejsobi.2008.09.013.

PEQUENO, P.L. de L.; ALMEIDA, C.M.V.V. de; MULLER, M.; LOCATELLI, M.; AMARAL, A.M. do; ARAÚJO, I.P. de. Fauna edáfica em área degradada submetida a recuperação utilizando intercultivo cacau $\mathrm{x}$ coco em Rondônia. In: CONGRESSO BRASILEIRO DE CIÊNCIA DO SOLO, 30., 2005, Recife. Solos, sustentabilidade e qualidade ambiental: anais. Recife: SBCS: Embrapa Solos - UEP Recife: UFRPE, 2005.

PEREIRA, R. de C.; ALBANEZ, J.M.; MAMÉDIO, I.M.P. Diversidade da meso e macrofauna edáfica em diferentes sistemas de manejo de uso do solo em Cruz das Almas-BA. Magistra, v.24, p.63-76, 2012.

PETERSEN, H.; LUXTON, M. A comparative analysis of soil fauna populations and their role in decomposition processes. Oikos, v.39, p.288-388, 1982. DOI: https://doi.org/10.2307/3544689.

PEZARICO, C.R.; LOPES, S. de M.; SILVA, R.F. da; RANGEL, M.A.S.; MERCANTE, F.M. Biodiversidade da macrofauna em solo cultivado com milho em sistemas de manejo orgânico e plantio direto. Revista Brasileira de Agroecologia, v.1, 2006.

PHILLIPS, H.R.P.; GUERRA, C.A.; BARTZ, M.L.C.; BRIONES, M.J.I.; BROWN, G.; CROWTHER, T.W.; FERLIAN, O.; GONGALSKY, K.B.; HOOGEN, J. van den; KREBS, J.; ORGIAZZI, A.; ROUTH, D.; SCHWARZ, B.; BACH, E.M.; BENNETT, J.; BROSE, U.; DECAËNS, T.; KÖNIG-RIES, B.; LOREAU, M.; MATHIEU, J.; MULDER, C.; VAN DER PUTTEN, W.H.; RAMIREZ, K.S.; RILLIG, M.C.; RUSSELL, D.; RUTGERS, M.; THAKUR, M.P.; DE VRIES, F.T.; WALL, D.H.; WARDLE, D.A.; ARAI, M.; AYUKE, F.O.; BAKER, G.H.; BEAUSÉJOUR, R.; BEDANO, J.C.; BIRKHOFER, K.; BLANCHART, E.; BLOSSEY, B.; BOLGER, T.; BRADLEY, R.L.; CALLAHAM, M.A.; CAPOWIEZ, Y.; CAULFIELD, M.E.; CHOI, A.; CROTTY, F.V.; DÁVALOS, A.; COSIN, D.J.D.; DOMINGUEZ, A.; DUHOUR, A.E.; EEKEREN, N. VAN; CHRISTOPH EMMERLING, C.; FALCO, L.B.; FERNÁNDEZ, R.; FONTE, S.J.; FRAGOSO, C.; GUTIÉRREZ LÓPEZ, M.G.; HACKENBERGER, D.K.; HERNÁNDEZ, L.M.; HISHI, T.; HOLDSWORTH, A.R.; HOLMSTRUP, M.; HOPFENSPERGER, K.N.; HUERTA LWANGA, E.; HUHTA, V.; HURISSO, T.T.; IANNONE III, B.V.; IORDACHE, M.; JOSCHKO, M.; KANEKO, N.; KANIANSKA, R.; AIDAN M. KEITH, A.M.; KELLY, C.A.; KERNECKER, M.L.; KLAMINDER, J.; KONÉ, A.W.; KOOCH, Y.; KUKKONEN, S.T.; LALTHANZARA, H.; LAMMEL, D.R.; LEBEDEV, I.M.; LI, Y.; JESUS LIDON, J.B.; LINCOLN, N.K.; LOSS, S.R.; MARICHAL, R.; MATULA, R.; MOOS, J.H.; MORENO, G.; MORÓN-RÍOS, A.MUYS, B.; NEIRYNCK, J.; NORGROVE, L.; NOVO, M.; NUUTINEN, V.;
VICTORIA NUZZO, V.; RAHMAN P, M.; PANSU, J.; SHISHIR PAUDEL, S.; PÉRÈS, G.; PÉREZ-CAMACHO, L.; PIÑEIRO, R.; PONGE, J.-F.; RASHID, M.I.; REBOLLO, S.; JAVIER RODEIRO-IGLESIAS, J.; RODRÍGUEZ, M.Á.; ROTH, A.M.; ROUSSEAU, G.X.; ROZEN, A.; SAYAD, E.; VAN SCHAIK, L.; SCHARENBROCH, B.C.; SCHIRRMANN, M.; SCHMIDT, O.; SCHRÖDER, B.; SEEBER, J.; SHASHKOV, M.P.; SINGH, J.; SMITH, S.M.; STEINWANDTER, M.; TALAVERA, J.A.; TRIGO, D.; TSUKAMOTO, J.; VALENÇA, A.W. de; VANEK, S.J.; VIRTO, I.; WACKETT, A.A.; WARREN, M.W.; WEHR, N.H.; WHALEN, J.K.; WIRONEN, M.B.; WOLTERS, V.; ZENKOVA, I.V.; ZHANG, W.; CAMERON, E.K.; EISENHAUER, N. Global distribution of earthworm diversity. Science, v.366, p.480-485, 2019. DOI: https://doi.org/ 10.1126/science.aax4851.

PIEARCE, T.G. The calcium relations of selected lumbricidae. Journal of Animal Ecology, v.41, p.167-188, 1972.

PIMENTEL, M.S. Indicadores da qualidade do solo em sistema orgânico de café, hortaliça, pasto e floresta, durante as estações do ano. 2005. 133p. Tese (Doutorado) - Universidade Federal Rural do Rio de Janeiro, Seropédica.

PIMENTEL, M.S.; AQUINO, A.M.; RICCI, M.S.; ALMEIDA, D.J.; DE-POLLI, H. Estudo preliminar sobre a ocorrência de macrofauna em solos submetidos à cafeicultura orgânica, pastagem e floresta. In: REUNIÃO BRASILEIRA DE FERTILIDADE DO SOLO E NUTRIÇÃO DE PLANTAS, 25.; REUNIÃO BRASILEIRA SOBRE MICORRIZAS, 9.; SIMPÓSIO BRASILEIRO DE MICROBIOLOGIA DO SOLO, 7.; REUNIÃO BRASILEIRA DE BIOLOGIA DO SOLO, 4., 2002, Rio de Janeiro. Agricultura: bases ecológicas para o desenvolvimento social e econômico sustentado: [anais]. [Rio de Janeiro]: SBCS: SBM: UFRRJ: Embrapa Solos; [Seropédica]: Embrapa Agrobiologia, 2002. FERTBIO 2002.

PIMENTEL, M.S.; CARVALHO, R.S.; MARTINS, L.M.V.; SILVA, A.V.L. da. Seasonal response of edaphic bioindicators using green manure in Brazilian semi-arid conditions. Revista Ciência Agronômica, v.42, p.829-836, 2011a. DOI: https://doi.org/10.1590/S1806-66902011000400002.

PIMENTEL, M.S.; DE-POLLI, H.; AQUINO, A.M. de; CORREIA, M.E.F.; ROUWS, J.R.C. Bioindicators of soil quality in coffee organic cultivation systems. Pesquisa Agropecuária Brasileira, v.46, p.546-553, 2011b. DOI: https://doi.org/10.1590/ S0100-204X2011000500013.

PODGAISKI, L.R.; MENDONÇA, M. de S.; PILLAR, V.D. O uso de atributos funcionais de invertebrados terrestres na ecologia: o que, como e por quê? Oecologia Australis, v.15, p.835-853, 2011. DOI: https://doi.org/10.4257/oeco.2011.1504.05.

POMPEO, P.N.; SANTOS, M.A.B. dos; BIASI, J. P.; SIQUEIRA, S. de F.; ROSA, M.G. da; BARETTA, C.R.D.M.; BARETTA, D. Fauna e sua relação com atributos edáficos em Lages, Santa Catarina - Brasil. Scientia Agraria, v.17, p.42-51, 2016. DOI: https://doi.org/10.5380/rsa.v17i1.46535.

PONTES, T.M. Estoques de biomassa e de nutrientes de pousios enriquecidos com Inga edulis Martius em áreas com histórico de agricultura e de pecuária no Assentamento TarumãMirím, Manaus- AM. 2009. Dissertação (Mestrado) - Instituto Nacional de Pesquisa da Amazônia, Manaus. 
PORTILHO, I.I.R.; CREPALDI, R.A.; BORGES, C.D.; SILVA, R.F. da; SALTON, J.C.; MERCANTE, F.M. Fauna invertebrada e atributos físicos e químicos do solo em sistemas de integração lavoura-pecuária. Pesquisa Agropecuária Brasileira, v.46, p.1310-1320, 2011. DOI: https://doi.org/10.1590/S0100204X2011001000027.

PULLEMAN, M.; CREAMER, R.; HAMER, U.; HELDER, J.; PELOSI, C.; PÉRÈS, G.; RUTGERS, M. Soil biodiversity, biological indicators and soil ecosystem services - an overview of European approaches. Current Opinion in Environmental Sustainability, v.4, p.529-538, 2012. DOI: https://doi.org/10.1016/j. cosust.2012.10.009.

RAIJ, B. van. Avaliação da fertilidade do solo. 3.ed. PiracicabaSP: Potafos, 1987. 142p.

REICH, P.B.; OLEKSYN, J.; MODRZYNSKI, J.; MROZINSKI, P.; HOBBIE, S.E.; EISSENSTAT, D.M.; CHOROVER, J.; CHADWICK, O.A.; HALE, C.M.; TJOELKER, M.G. Linking litter calcium, earthworms and soil properties: a common garden test with 14 tree species. Ecology Letters, v.8, p.811-818, 2005. DOI: https://doi.org/10.1111/j.1461-0248.2005.00779.x.

RESSETTI, R.R. Abundance, biomass and species of earthworm in ecosystems of urban areas. Scientia Agraria, v.7, p.61-66, 2006.

RESSETTI, R.R.; DIONÍSIO, J.A.; MOTTA, A.C.V. Comparação entre doses de Alil isotiocianato e a solução de formaldeído na extração de minhocas. Bragantia, v.67, p.25-33, 2008. DOI: https://doi.org/10.1590/S0006-87052008000100003.

REYNOLDS, J.W.; JORDAN, G.A. A preliminary conceptual model of megadrile activity and abundance in the Haliburton Highlands. Megadrilogica, v.2, p.1-11, 1975.

RIBEIRO, A.C.; GUIMARÃES, P.T.G.; ALVAREZ V., V.H. (Ed.). Recomendações para o uso de corretivos e fertilizantes em Minas Gerais: 5a Aproximação. Viçosa: Comissão de Fertilidade do Solo do Estado de Minas Gerais, 1999. 359p.

RICCI, M. dos S.F.; AQUINO, A.M. de; SILVA, E.M.R. da; PEREIRA, J.C.; REIS, V.M. Transformações biológicas e microbiológicas ocorridas no solo de um cafezal convencional em conversão para orgânico. Seropédica: Embrapa Agrobiologia, 1999. 10p. (Embrapa Agrobiologia. Comunicado técnico, 31).

RICHARD, B.; DECAËNS, T.; ROUGERIE, R.; JAMES, S.W.; PORCO, D.; HEBERT, P.D.N. Re-integrating earthworm juveniles into soil biodiversity studies: species identification through DNA barcoding. Molecular Ecology Resources, v.10, p.606-614, 2010. DOI: https://doi.org/10.1111/j.1755-0998.2009.02822.x.

RIGHI, G. Minhocas da América Latina: diversidade, função e valor. In: CONGRESSO BRASILEIRO DE CIÊNCIA DO SOLO, 26., 1997, Rio de Janeiro. Informação, globalização, uso do solo: anais. Viçosa: SBCS, 1997.

RODRIGUES, K. de M.; CORREIA, M.E.F.; ALVES, B.J.R.; AQUINO, A.M. de. Efeitos do manejo do solo e sucessão de culturas na abundância e na dieta da minhoca, Pontoscolex corethrurus, por marcação isotópica. In: REUNIÃO BRASILEIRA DE FERTILIDADE DO SOLO E NUTRIÇÃO DE PLANTAS, 26.; REUNIÃO BRASILEIRA SOBRE MICORRIZAS, 10.; SIMPÓSIO BRASILEIRO DE MICROBIOLOGIA DO SOLO,
7.; REUNIÃO BRASILEIRA DE BIOLOGIA, 5., 2004, Lages. Avaliação das conquistas: bases para estratégias futuras. Lages: SBCS: UDESC Lages, 2004. FERTBIO 2004.

RÖMBKE, J. Searching for a standardization of quantitative terrestrial oligochaete sampling methods: the ISO methodology. In: BROWN, G.G.; FRAGOSO, C. (Ed.). Minhocas na América Latina: biodiversidade e ecologia. Londrina: Embrapa Soja, 2007. p.497-505.

RÖMBKE, J.; GARDI, C.; CREAMER, R.; MIKO, L. Soil biodiversity data: actual and potential use in European and national legislation. Applied Soil Ecology, v.97, p.125-133, 2016. DOI: https://doi.org/10.1016/j.apsoil.2015.07.003.

RÖMBKE, J.; JÄNSCH, S.; DIDDEN, W. The use of earthworms in ecological soil classification and assessment concepts. Ecotoxicology and Environmental Safety, v.62, p.249-265, 2005. DOI: https://doi.org/10.1016/j.ecoenv.2005.03.027.

RÖMBKE, J.; JÄNSCH, S.; ROSS-NICKOLL, M.; TOSCHKI, A.; HÖFER, H.; HORAK, F.; RUSSELL, D.; BURKHARDT, U.; SCHMITT, H. Erfassung und analyse des bodenzustands im Hinblick auf die umsetzung und weiterentwicklung der nationalen biodiversitätsstrategie. Dessau-Roblau: Umweltbundesamt, 2012. 386p. (UBA. Texte n. 33/2012).

RÖMBKE, J.; MELLER, M.; GARCÍA, M. Earthworm densities in central Amazonian primary and secondary forests and a polyculture forestry plantation. Pedobiologia, v.43, p.518-522, 1999.

RÖMBKE, J.; SCHMIDT, P.; HÖFER, H. The earthworm fauna of regenerating forests and anthropogenic habitats in the coastal region of Paraná. Pesquisa Agropecuária Brasileira, v.44, p.1040-1049, 2009. DOI: https://doi.org/10.1590/S0100$204 X 2009000800037$.

RÖMBKE, J.; SOUSA, J.-P.; SCHOUTEN, T.; RIEPERT, F. Monitoring of soil organisms: a set of standardized field methods proposed by ISO. European Journal of Soil Biology, v.42, p.S61-S64, 2006. Supplement 1. DOI: https://doi.org/10.1016/j. ejsobi.2006.07.016.

ROMERO-FREIRE, A.; MARTÍN PEINADO, F.J.; DÍEZ ORTIZ, $M$. Influence of soil properties on the bioaccumulation and effects of arsenic in the earthworm Eisenia andrei. Environmental Science Pollution Research, v.22, p.15016-15028, 2015. DOI: https://doi.org/10.1007/s11356-015-4659-4.

ROSSI, J.-P.; MATHIEU, J.; COOPER, M.; GRIMALDI, M. Soil macrofaunal biodiversity in Amazonian pastures: matching sampling with patterns. Soil Biology and Biochemistry, v.38, p.2178-2187, 2006. DOI: https://doi.org/10.1016/j. soilbio.2006.01.020.

ROUSSEAU, G.X.; SILVA, P.R. dos S.; CARVALHO, C.J.R. de. Earthworms, ants and other arthropods as soil health indicators in traditional and no-fire agro-ecosystems from Eastern Brazilian Amazonia. Acta Zoológica Mexicana, v.26, p.117134, 2010. Número especial 2. DOI: https://doi.org/10.21829/ azm.2010.262882.

ROUSSEAU, G.X.; SILVA, P.R. dos S.; CELENTANO, D.; CARVALHO, C.J.R. de. Macrofauna do solo em uma cronosequência de capoeiras, florestas e pastos no Centro de 
Endemismo Belém, Amazônia Oriental. Acta Amazonica, v.44, p.499-512, 2014. DOI: https://doi.org/10.1590/18094392201303245.

RUTGERS, M.; ORGIAZZI, A.; GARDI, C.; RÖMBKE, J.; JÄNSCH, S.; KEITH, A.M.; NEILSON, R.; BOAG, B.; SCHMIDT, O.; MURCHIE, A.K.; BLACKSHAW, R.P.; PÉRÈS, G.; CLUZEAU, D.; GUERNION, M.; BRIONES, M.J.I.; RODEIRO, J.; PIÑEIRO, R.; COSÍN, D.J.D.; SOUSA, J.P.; SUHADOLC, M.; KOS, I.; KROGH, P.-H.; FABER, J.H.; MULDER, C.; BOGTE, J.J.; WIJNEN, H.J. VAN; SCHOUTEN, A.J.; ZWART, D. de. Mapping earthworm communities in Europe. Applied Soil Ecology, v.97, p.98-111, 2016. DOI: https://doi.org/10.1016/j.apsoil.2015.08.015.

SANTOS, A.; MAIA, L. dos S.; FERREIRA, T.; DEMETRIO, W.C.; NADOLNY, H.S.; RIBEIRO, L.V.; SCHIEDECK, G.; COSTA, F.A. da; BARTZ, M.L.C.; BROWN, G.G. (Ed.). Minhocas como bioindicadoras da qualidade do solo em ecossistemas na Embrapa Clima Temperado. Pelotas: Embrapa Clima Temperado, 2019. 37p. (Embrapa Clima Temperado. Documentos 418).

SANTOS, D.P.; SANTOS, I.L. dos; SOUZA, T.R.S. de; JUNIOR, J.P. da S.; SANTOS, G.G.; MARCHÃO, R.L. Macrofauna edáfica sob sistemas de manejo em Latossolo do Cerrado piauiense. In: CONGRESSO BRASILEIRO DE CIÊNCIA DO SOLO, 34., 2013, Florianópolis. Ciência do solo: para quê e para quem: anais. Florianópolis: SBCS, 2013. Available at: $<$ http://www.alice.cnptia. embrapa.br/alice/bitstream/doc/976276/1/33793.pdf $>$. Accessed on: June 152015.

SANTOS, D.P.; SCHOSSLER, T.R.; SANTOS, I.L. dos; MELO, N.B.; SANTOS, G.G. Soil macrofauna in a Cerrado/ Caatinga ecotone under different crops in Southwestern Piauí State, Brazil. Ciência Rural, v.47, e20160937, 2017. DOI: https://doi.org/10.1590/0103-8478cr20160937.

SANTOS, E. dos; SANTOS, R.C. dos; MARQUES, R. Macrofauna edáfica na interface solo-serrapilheira e a relação com atributos químicos de um Espodossolo sob dois diferentes sistemas de conservação e uso do solo no Município de ParanaguáPR. Enciclopédia Biosfera, v.11, p.2294-2307, 2015.

SANTOS, E. dos; VARGAS, G.R. de; MELLO FILHO, N.R. de; GARDNER, G.B. Comparação entre diferentes métodos de coleta de minhocas em dois diferentes sistemas florestais. Scientia Vitae, v.3, p.34-40, 2016.

SANTOS, G.G.; SILVEIRA, P.M. da; MARCHÃO, R.L.; BECQUER, T.; BALBINO, L.C. Macrofauna edáfica associada a plantas de cobertura em plantio direto em um Latossolo Vermelho do Cerrado. Pesquisa Agropecuária Brasileira, v.43, p.115-122, 2008. DOI: https://doi.org/10.1590/S0100-204X2008000100015.

SANTOS, H.G. dos; JACOMINE, P.K.T.; ANJOS, L.H.C. dos; OLIVEIRA, V.A. de; LUMBRERAS, J.F.; COELHO, M.R.; ALMEIDA, J.A. de; ARAUJO FILHO, J.C. de; OLIVEIRA, J.B. de; CUNHA, T.J.F. Sistema brasileiro de classificação de solos. 5.ed. rev. e ampl. Brasília: Embrapa, 2018. 356p.

SATCHELL, J.E. Lumbricidae. In: BURGES, A.; RAW, F. (Ed.). Soil biology. London: Academic Press, 1967. p.259-322.
SCHIAVON, G. de A. Fauna edáfica em diferentes sistemas de manejo: avaliações sob a ótica acadêmica e do conhecimento local. 2012. 97p. Dissertação (Mestrado) - Universidade Federal de Pelotas, Pelotas.

SCHIAVON, G. de A.; SCHIEDECK, G.; VIANNA, É.E.S.; SCHWENGBER, J.E. Biodiversidade de minhocas do solo na Estação Experimental Cascata, Embrapa Clima Temperado, Pelotas, RS. Pelotas: Embrapa Clima Temperado, 2009. 27p. (Embrapa Clima Temperado. Boletim de Pesquisa e Desenvolvimento, 112).

SILVA, D.C. da; PEREIRA, J. de M.; PINTO, L.V.A.; BARETTA, D. Fauna edáfica como indicadora de qualidade do solo em fragmentos florestais e área sob cultivo do cafeeiro. In: JORNADA CIENTÍFICA E TECNOLÓGICA, 6; SIMPÓSIO DE PÓS-GRADUAÇÃO DO IFSULDEMINAS, 3., 2014, Pouso Alegre. Anais. Pouso Alegre: IFSULDEMINAS, 2014.

SILVA, D.M.M.H. da. Macrofauna edáfica, biomassa microbiana e qualidade do solo em área cultivada no Cerrado Amapaense com e sem uso do fogo e adubação alternativa. 2009. 55p. Dissertação (Mestrado) - Universidade Federal do Amapá, Macapá.

SILVA, E. da. Impact des plantations forestières sur l'abondance et la diversité des vers de terre, et sur les attributs physiques et chimiques du sol: mémoire de stage. Colombo: Embrapa Florestas: Universidade do Paraná; [Paris]: Université Paris-Est Créteil Val-de-Marne, 2010. 49p.

SILVA, E. da; LIMA, O.G. de; ANDRADE, D.P. de; BROWN, G.G. Earthworm populations in forestry plantations (Araucaria angustifolia, Pinus elliottii) and Native Atlantic forest in Southern Brazil compared using two sampling methods. Pedobiologia, v.72, p.1-7, 2019. DOI: https://doi.org/10.1016/j.pedobi.2018.10.002.

SILVA, L.L.G.G. da; RESENDE, A.S. de; DIAS, P.F.; CORREIA, M.E.F.; SCORIZA, R.N. Soil macrofauna in wooded pasture with legume trees. Ciência Rural, v.45, p.1191-1197, 2015a. DOI: https://doi.org/10.1590/0103-8478cr20131569.

SILVA, R.B. da; PEQUENO, P.L. de L.; ALMEIDA, C.M.V.C. de; BATISTA, C.C.; BURAK, S.C.; SOUZA, M. da S.; SOUZA, M.B.L.; BEZERRA, I.L. Avaliação inicial da fauna edáfica em três classes de solos utilizados com café arborizado em Rondônia. In: CONGRESSO BRASILEIRO DE CIÊNCIA DO SOLO, 30., 2005, Recife. Solos, sustentabilidade e qualidade ambiental: anais. Recife: SBCS: Embrapa Solos - UEP Recife: UFRPE, 2005.

SILVA, R.F. da; AQUINO, A.M. de; MERCANTE, F.M.; GUIMARÃES, M. de F. Populações de oligoquetos (Annelida: Oligochaeta) em um Latossolo Vermelho submetido a sistemas de uso do solo. Ciência Rural, v.36, p.673-677, 2006. DOI: https://doi.org/10.1590/S0103-84782006000200051.

SILVA, R.F. da; OTSUBO, A.A.; AQUINO, A.M.de; MERCANTE, F.M.; ARAÚJO, H.S. de. Comunidade da macrofauna do solo em sistemas de cultivo de mandioca sob plantio direto e convencional em Mato Grosso do Sul, Brasil. In: CONGRESO LATINO AMERICANO DE LA CIENCIA DEL SUELO, 15.; CUBANO DE LA CIENCIA DEL SUELO, 5., 2001, Varadero. Anales. Habana: Sociedad Latinoamericana de la Ciencia del Suelo, 2001. 
SILVA, R.F. da; TOMAZI, M.; PEZARICO, C.R.; AQUINO, A.M. de; MERCANTE, F.M. Macrofauna invertebrada edáfica em cultivo de mandioca sob sistemas de cobertura do solo. Pesquisa Agropecuária Brasileira, v.42, p.865-871, 2007. DOI: https://doi.org/10.1590/S0100-204X2007000600014.

SILVA, R.H.P. da; RODRIGUES, I.P.S.; GUIMARÃES, A.Q.; DRUMOND, M.A. Comportamento de construção de câmara de estivação por Rhinodrilus alatus e sua relação com a pluviosidade. In: ENCONTRO LATINO-AMERICANO DE ECOLOGIA E TAXONOMIA DE OLIGOQUETAS, 5.; SIMPÓSIO ENGENHEIROS EDÁFICOS, FERTILIDADE DO SOLO E TERRA PRETA DE ÍNDIO (TPI), 2015, Curitiba. Anais. [S.1.]: Federação Brasileira de Plantio Direto de Irrigação, 2015b. $5^{\circ}$ ELAETAO.

SISINNO, C.L.S.; NIEMEYER, J.C.; SEGAT, J.C.; OLIVEIRA FILHO, L.C.I.; NIVA, C.C.; BROWN, G.G. Importância e aplicações dos ensaios ecotoxicológicos com oligoquetas. In: NIVA, C.C.; BROWN, G.G. (Ed.). Ecotoxicologia terrestre: métodos e aplicações dos ensaios com oligoquetas. Brasília: Embrapa, 2019. p.45-70.

SOUZA, M.E.P. de. Oligochaetas em solos sob sistemas de manejos a pleno sol e agroflorestal e vermicompostagem associada com pós de rochas. 2010. 58p. Dissertação (Magister Scientiae) - Universidade Federal de Viçosa, Viçosa.

SPARLING, G.; LILBURNE, L.; VOJVODIC-VUKOVIC, M. Provisional targets for soil quality indicators in New Zealand. Lincoln: Manaaki Whenua Press, 2008. 64p. (Landcare Research Science Series, n.34).

STEFFEN, G.P.K. Diversidade de minhocas e sua relação com ecossistemas naturais e alterados no estado do Rio Grande do Sul. 2012. 208p. Tese (Doutorado) - Universidade Federal de Santa Maria, Santa Maria.

STEFFEN, G.P.K.; ANTONIOLLI, Z.I.; STEFFEN, R.B.; JACQUES, R.J.S. Importância ecológica e ambiental das minhocas. Revista de Ciências Agrárias, v.36, p.137-147, 2013.

STOCKDALE, E.A.; WATSON, C. Managing soil biota to deliver ecosystem services. [Newcastle]: Natural England, 2012. 141p. (Natural England Commissioned Reports NECR 100).

SWIFT, M.; BIGNELL, D. Standard methods for assessment of soil biodiversity and land use practice. Bogor: International Centre for Research in Agroforestry, 2001. 40p.

TANCK, B.C.B. Flutuação populacional do oligochaeta edáfico Amynthas spp. (Kinberg, 1867) em quatro ecossistemas, através de dois métodos de extração. 1996. 118p. Dissertação (Mestrado) - Universidade Federal do Paraná, Curitiba.

TANCK, B.C.B.; SANTOS, H.R.; DIONÍSIO, J.A. Influência de diferentes sistemas de uso e manejo do solo sobre a flutuação populacional do oligochaeta edáfico Amynthas spp. Revista Brasileira de Ciência do Solo, v.24, p.409-415, 2000. DOI: https://doi.org/10.1590/S0100-06832000000200017.

TAPIA-CORAL, S.C.; VELÁSQUEZ, E.; JAMES, S.W.; LUIZÃO, F.J. Relações entre populações de minhocas (Annelida : Oligochaeta) e atributos químicos do solo em sistemas agroflorestais manejados na Amazônia Brasileira. In: ENCONTRO LATINO-AMERICANO DE ECOLOGIA E TAXONOMIA DE
OLIGOQUETAS, 5.; SIMPÓSIO ENGENHEIROS EDÁFICOS, FERTILIDADE DO SOLO E TERRA PRETA DE ÍNDIO (TPI), 2015, Curitiba. Anais. [S.1.]: Federação Brasileira de Plantio Direto de Irrigação, 2015. p.41-42. $5^{\circ}$ ELAETAO.

TARRÁ, I.L.C. Relações entre os grupos funcionais da macrofauna e o volme dos macroporos do solo em sistemas agrossilviculturais da Amazônia Central. 2003. 73p. Dissertação (Mestrado) - Instituto Nacional de Pesquisas da Amazônia, Universidade Federal do Amazonas, Manaus.

TARRÁ, I.L.C.; LUIZÃO, F. de J.; WANDELLI, E.V.; TEIXEIRA, W.G.; MORAIS, W.J.; FERNANDES, E.C.M.; BROCHEL, K.V.; PÉREZ, N.V. Grupos funcionais da macrofauna e macroporos do solo em sistemas agroflorestais da Amazônia central. Prospectiva, v.10, p.6-17, 2012. DOI: https://doi.org/10.15665/ rp.v10i1.391.

TIWARI, S.C. Effects of organic manure and NPK fertilization on earthworm activity in an Oxisol. Biology and Fertility of Soils, v.16, p.293-295, 1993. DOI: https://doi.org/10.1007/BF00369307.

TRIANA, S.P. Impacto da degradação de florestas ripárias na composição e diversidade da macrofauna do solo. 2014. 60 p. Dissertação (Mestrado) - Universidade Estadual do Maranhão, São Luís.

TROGELlO, E.; TROGELlO, A.G.; SILVEIRA, E.R. Avaliação da fauna do solo em diferentes sistemas de cultivo, milho orgânico e milho em plantio direto. Revista Brasileira de Biociências, v.6, p.25-26, 2008. Suplemento 1.

UNIVERSITY OF MINNESOTA. Great Lakes Worm Watch: research methods. Available at: $<$ http://greatlakeswormwatch.org/ research/methods_worms_biomass.html>. Accessed on: Apr. 15 2020.

UZÊDA, M.C.; GARCIA, M.A.; COSTA, J.R. Análise das relações entre populações de enchytraeidae e minhocas e seu uso como bioindicador da qualidade do solo. In: BROWN, G.G.; FRAGOSO, C. (Ed.). Minhocas na América Latina: biodiversidade e ecologia. Londrina: Embrapa Soja, 2007. p.489495.

VASCONCELLOS, R.L.F.; SEGAT, J.C.; BONFIM, J.A.; BARETTA, D.; CARDOSO, E.J.B.N. Soil macrofauna as an indicator of soil quality in an undisturbed riparian forest and recovering sites of different ages. European Journal of Soil Biology, v.58, p.105-112, 2013. DOI: https://doi.org/10.1016/j. ejsobi.2013.07.001.

VELÁSQUEZ, E.; FONTE, S.J.; BAROT, S.; GRIMALDI, M.; DESJARDINS, T.; LAVELLE, P. Soil macrofauna-mediated impacts of plant species composition on soil functioning in Amazonian pastures. Applied Soil Ecology, v.56, p.43-50, 2012. DOI: https://doi.org/10.1016/j.apsoil.2012.01.008.

VENDRAME, P.R.S. Relações entre a mineralogia, fertilidade, acidez e macrofauna em Latossolos do Cerrado sob pastagem. 2008. 116p. Tese (Doutorado) - Universidade Estadual de Londrina, Londrina.

VENDRAME, P.R.S.; MARCHÃO, R.L.; BRITO, O.R.; GUIMARÃES, M. de F.; BECQUER, T. Relationship between macrofauna, mineralogy and exchangeable calcium and magnesium in Cerrado Oxisols under pasture. Pesquisa 
Agropecuária Brasileira, v.44, p.996-1001, 2009. DOI: https://doi.org/10.1590/S0100-204X2009000800031.

VERSTEEGH, E.A.A.; BLACK, S.; HODSON, M.E. Environmental controls on the production of calcium carbonate by earthworms. Soil Biology and Biochemistry, v.70, p.159-161, 2014. DOI: https://doi.org/10.1016/j.soilbio.2013.12.013.

VIANA, R. de M. Indicadores de qualidade de solo para avaliação da restauração florestal: estudo de caso UHE Balbina - AM. 2012. 65p. Dissertação (Mestrado) - Instituto Nacional de Pesquisas da Amazônia, Manaus.

VICENTE, N.M. de F.; CURTINHAS, J.N.; PEREZ, A.L.; PREZOTTI, L. Fauna edáfica auxiliando a recuperação de áreas degradadas do Córrego Brejaúba, MG. Floresta e Ambiente, v.17, p.104-110, 2010. DOI: https://doi.org/10.4322/floram.2011.013.
VOSS, M. População de minhocas em diferentes sistemas de plantio. Plantio Direto, v.4, p.6-7, 1986.

WILSON, E.F.; BROWN, G.G.; DREWES, C.D. Characterization of phosphorus metabolism during six stages of development in the earthworm Eisenia foetida using ${ }^{31}$ P-NMR. Comparative Biochemistry and Physiology Part B: Comparative Biochemistry, v.102B, p.383-388, 1992. DOI: https://doi.org/10.1016/0305-0491(92)90139-I.

ZABORSKI, E.R. Allyl isothiocyanate: an alternative chemical expellant for sampling earthworms. Applied Soil Ecology, v.22, p.87-95, 2003. DOI: https://doi.org/10.1016/S0929-1393(02)00106-3.

ZAGATTO, M.R.G. Fauna edáfica em sistemas de uso do solo no município de Ponta Grossa-PR. 2014. 68p. Dissertação (Mestrado) - Universidade Federal do Paraná, Curitiba. 